Prepared in cooperation with the Kansas Department of Health and Environment and the U.S. Army Corps of Engineers, Kansas City District

\title{
Spatial Variability of Harmful Algal Blooms in Milford Lake, Kansas, July and August 2015
}

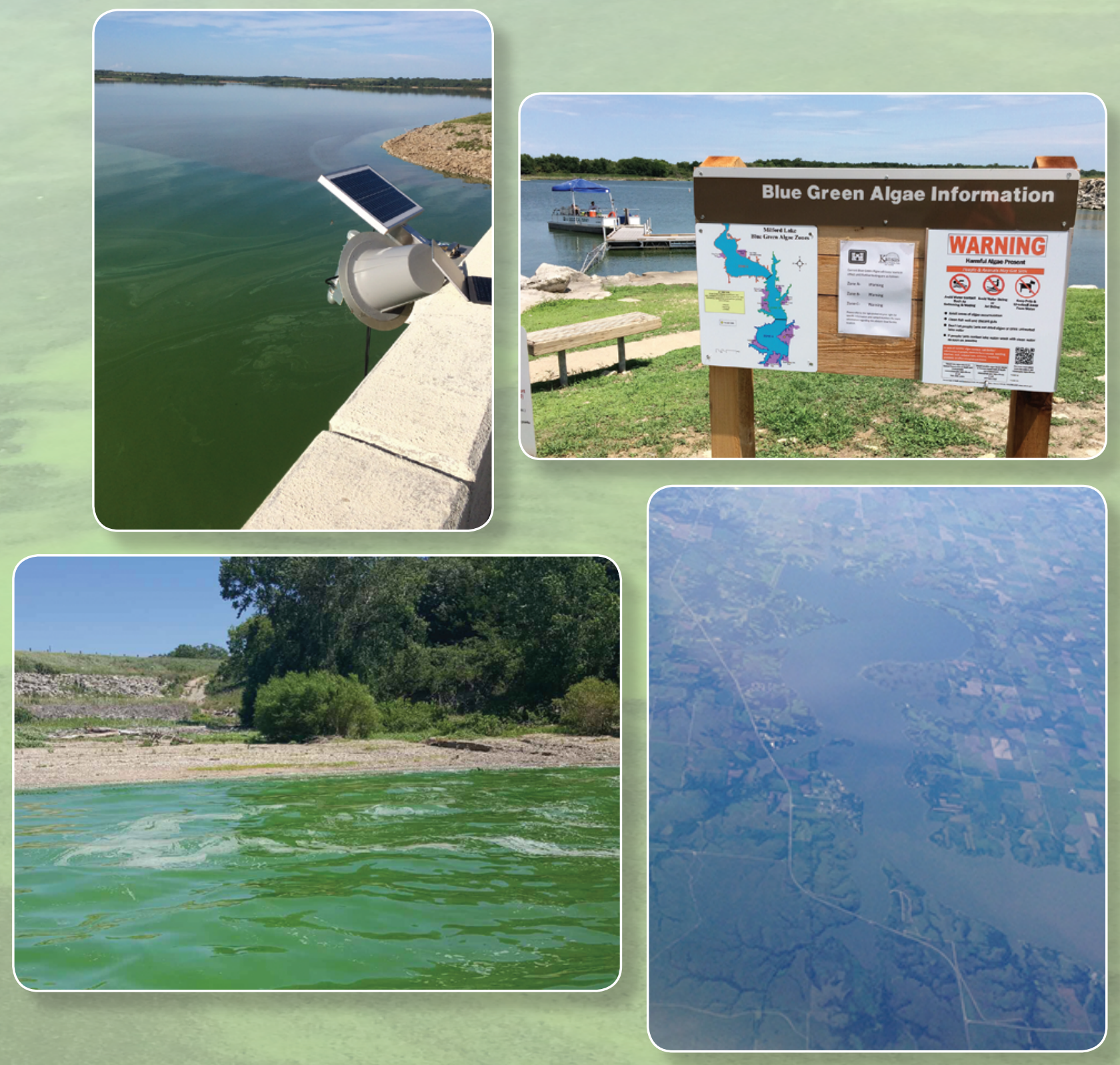

Scientific Investigations Report 2016-5168

U.S. Department of the Interior

U.S. Geological Survey 

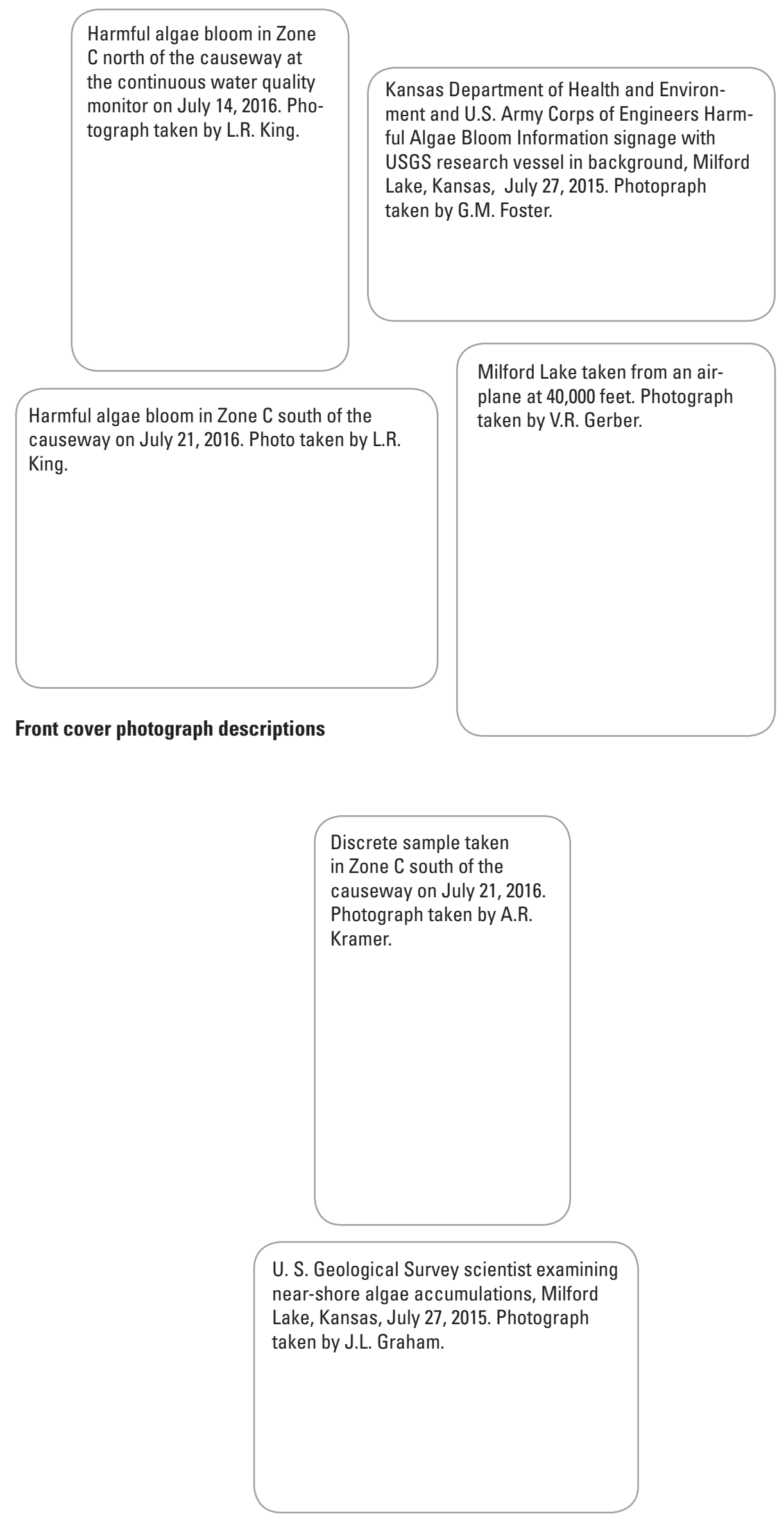

Back cover photograph descriptions 


\section{Spatial Variability of Harmful Algal Blooms in Milford Lake, Kansas, July and August 2015}

By Guy M. Foster, Jennifer L. Graham, Tom C. Stiles, Marvin G. Boyer, Lindsey R. King, and Keith A. Loftin

Prepared in cooperation with the Kansas Department of Health and Environment and the U.S. Army Corps of Engineers, Kansas City District

Scientific Investigations Report 2016-5168 


\section{U.S. Department of the Interior SALLY JEWELL, Secretary}

\section{U.S. Geological Survey Suzette M. Kimball, Director}

\section{U.S. Geological Survey, Reston, Virginia: 2017}

For more information on the USGS - the Federal source for science about the Earth, its natural and living resources, natural hazards, and the environment—visit http://www.usgs.gov or call 1-888-ASK-USGS.

For an overview of USGS information products, including maps, imagery, and publications, visit http://store.usgs.gov/.

Any use of trade, firm, or product names is for descriptive purposes only and does not imply endorsement by the U.S. Government.

Although this information product, for the most part, is in the public domain, it also may contain copyrighted materials as noted in the text. Permission to reproduce copyrighted items must be secured from the copyright owner.

Suggested citation:

Foster, G.M., Graham, J.L., Stiles, T.C., Boyer, M.G., King, L.R., and Loftin, K.A., 2017, Spatial variability of harmful algal blooms in Milford Lake, Kansas, July and August 2015: U.S. Geological Survey Scientific Investigations Report 2016-5168, 45 p., https://doi.org/10.3133/sir20165168.

ISSN 2328-0328 (online) 


\section{Contents}

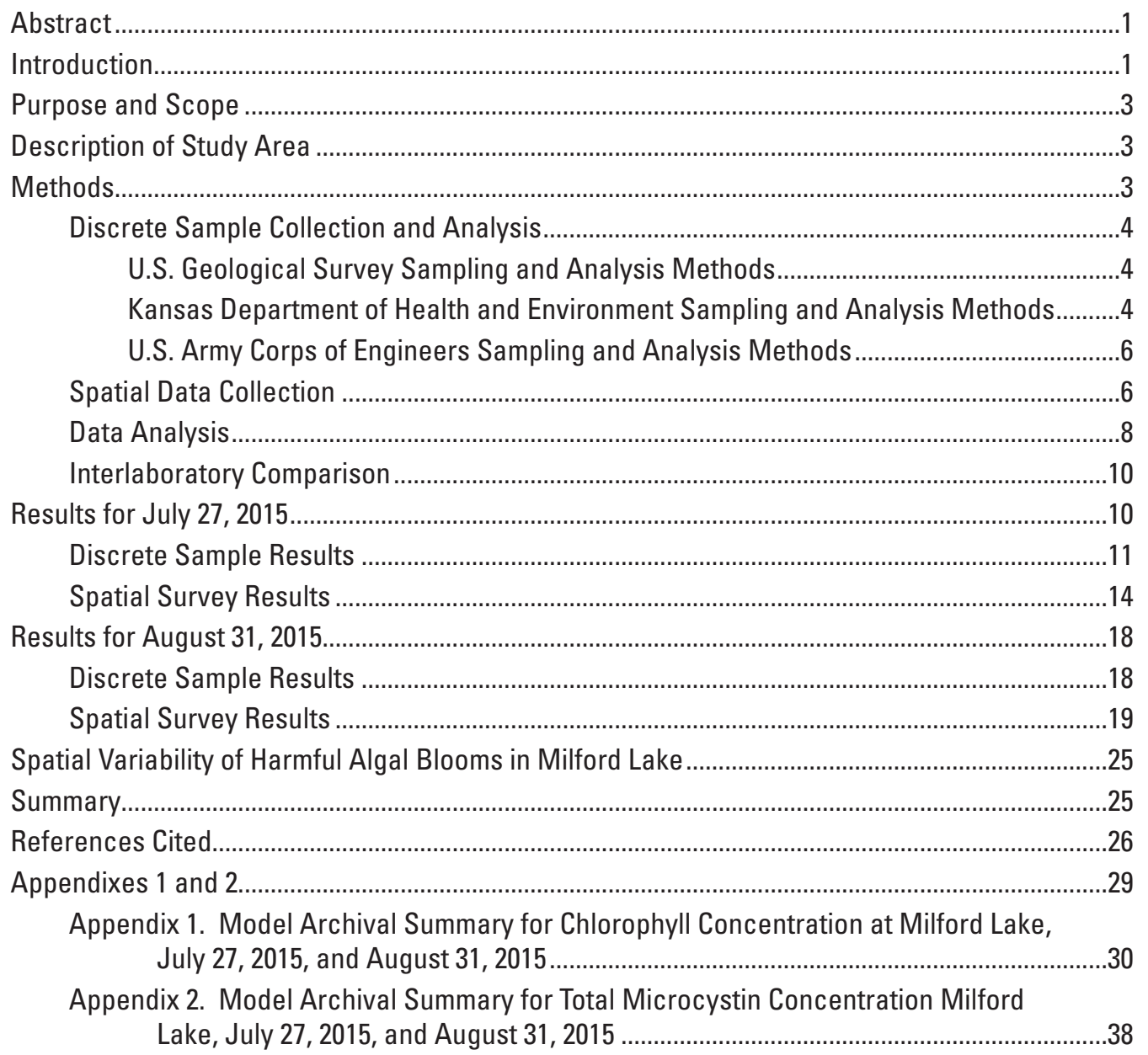

\section{Figures}

1. Map showing Milford Lake, including all study sites and zones used to issue public-health advisories.

2. Photographs showing mounted sensor-array used for spatial data collection.................7

3. Graphs showing comparison between top-sensor measured phycocyanin and laboratory-measured chlorophyll and total microcystin.

4. Graph showing comparison of total microcystin concentrations in split-replicate samples collected by the U.S. Geological Survey, Kansas Department of Health and Environment, and U.S. Army Corps of Engineers.

5. Map showing total microcystin concentration in discrete water-quality samples collected by the U.S. Geological Survey, the Kansas Department of Health and Environment, and the U.S. Army Corps of Engineers on July 27, 2015.

6. Maps showing regression-estimated chlorophyll concentrations in Milford Lake on July 27, 2015

7. Box plots of regression-estimated chlorophyll and total microcystin concentrations in Milford Lake Zones A, B, and C on July 27, 2015. 
8. Maps showing regression-estimated total microcystin concentrations in Milford Lake on July 27, 2015.

9. Map showing total microcystin concentration in discrete water-quality samples collected by the U.S. Geological Survey, the Kansas Department of Health and Environment, and the U.S. Army Corps of Engineers on August 31, 2015

10. Maps showing regression-estimated chlorophyll concentrations in Milford Lake on August 31, 2015

11. Box plots of regression-estimated chlorophyll and total microcystin concentrations in Milford Lake Zones A, B, and C on August 31, 2015.

12. Maps showing regression-estimated total microcystin concentrations in Milford Lake on August 31, 2015.

\section{Tables}

1. Milford Lake discrete water-quality sampling sites, including sampling agency, sample type, analyses, and dates sampled.

2. Total microcystin concentration and cyanobacterial abundance in discrete waterquality samples collected by the U.S. Geological Survey, the Kansas Department of Health and Environment, and the U.S. Army Corps of Engineers on July 27, 2015

3. Summary statistics for regression estimated chlorophyll and total microcystin concentrations in Milford Lake on July 27, 2015

4. Total microcystin concentration and cyanobacterial abundance in discrete waterquality samples collected by the U.S. Geological Survey, the Kansas Department of Health and Environment, and the U.S. Army Corps of Engineers on August 31, 2015.

5. Summary statistics for regression estimated chlorophyll and total microcystin concentrations in Milford Lake on August 31, 2015 


\section{Conversion Factors}

\begin{tabular}{|c|c|c|}
\hline Multiply & By & To obtain \\
\hline \multicolumn{3}{|c|}{ Length } \\
\hline micrometer $(\mu \mathrm{m})$ & 0.00003937 & inch (in.) \\
\hline millimeter (mm) & 0.03937 & inch (in.) \\
\hline meter $(\mathrm{m})$ & 3.281 & foot $(\mathrm{ft})$ \\
\hline kilometer (km) & 0.6214 & mile (mi) \\
\hline \multicolumn{3}{|c|}{ Area } \\
\hline square kilometer $\left(\mathrm{km}^{2}\right)$ & 0.3861 & square mile $\left(\mathrm{mi}^{2}\right)$ \\
\hline \multicolumn{3}{|c|}{ Volume } \\
\hline milliliter (mL) & 0.0338 & ounce, fluid (oz) \\
\hline liter (L) & 0.2642 & gallon (gal) \\
\hline cubic hectometer $\left(\mathrm{hm}^{3}\right)$ & 810.7 & acre-foot (acre-ft) \\
\hline \multicolumn{3}{|c|}{ Flow rate } \\
\hline meter per second $(\mathrm{m} / \mathrm{s})$ & 3.281 & foot per second $(\mathrm{ft} / \mathrm{s})$ \\
\hline cubic meter per second $\left(\mathrm{m}^{3} / \mathrm{s}\right)$ & 35.31 & cubic foot per second $\left(\mathrm{ft}^{3} / \mathrm{s}\right)$ \\
\hline \multicolumn{3}{|c|}{ Mass } \\
\hline milligram (mg) & 0.00003527 & ounce, avoirdupois, (oz) \\
\hline microgram $(\mu \mathrm{g})$ & 0.00000003527 & ounce, avoirdupois, (oz) \\
\hline
\end{tabular}

\section{Datum}

Horizontal coordinate information is referenced to the North American Datum of 1983 (NAD 83).

\section{Supplemental Information}

Temperature in degrees Celsius $\left({ }^{\circ} \mathrm{C}\right)$ may be converted to degrees Fahrenheit $\left({ }^{\circ} \mathrm{F}\right)$ as follows:

${ }^{\circ} \mathrm{F}=\left(1.8 \times{ }^{\circ} \mathrm{C}\right)+32$.

Concentrations of chemical constituents in water are given in either milligrams per liter (mg/L) or micrograms per liter $(\mu \mathrm{g} / \mathrm{L})$. 



\title{
Spatial Variability of Harmful Algal Blooms in Milford Lake, Kansas, July and August 2015
}

\author{
By Guy M. Foster, ${ }^{1}$ Jennifer L. Graham, ${ }^{1}$ Tom C. Stiles, ${ }^{2}$ Marvin G. Boyer, ${ }^{3}$ Lindsey R. King, ${ }^{1}$ and Keith A. Loftin
}

\section{Abstract}

Cyanobacterial harmful algal blooms (CyanoHABs) tend to be spatially variable vertically in the water column and horizontally across the lake surface because of in-lake and weather-driven processes and can vary by orders of magnitude in concentration across relatively short distances (meters or less). Extreme spatial variability in cyanobacteria and associated compounds poses unique challenges to collecting representative samples for scientific study and public-health protection. The objective of this study was to assess the spatial variability of cyanobacteria and microcystin in Milford Lake, Kansas, using data collected on July 27 and August 31, 2015. Spatially dense near-surface data were collected by the U.S. Geological Survey, nearshore data were collected by the Kansas Department of Health and Environment, and open-water data were collected by U.S. Army Corps of Engineers. CyanoHABs are known to be spatially variable, but that variability is rarely quantified. A better understanding of the spatial variability of cyanobacteria and microcystin will inform sampling and management strategies for Milford Lake and for other lakes with CyanoHAB issues throughout the Nation.

The CyanoHABs in Milford Lake during July and August 2015 displayed the extreme spatial variability characteristic of cyanobacterial blooms. The phytoplankton community was almost exclusively cyanobacteria (greater than 90 percent) during July and August. Cyanobacteria (measured directly by cell counts and indirectly by regression-estimated chlorophyll) and microcystin (measured directly by enzyme-linked immunosorbent assay [ELISA] and indirectly by regression estimates) concentrations varied by orders of magnitude throughout the lake. During July and August 2015, cyanobacteria and microcystin concentrations decreased in the downlake (towards the outlet) direction.

Nearshore and open-water surface grabs were collected and analyzed for microcystin as part of this study. Samples were collected in the uplake (Zone C), midlake (Zone B), and downlake (Zone A) parts of the lake. Overall, no consistent pattern was indicated as to which sample location (nearshore

${ }^{1}$ U.S. Geological Survey.

${ }^{2}$ Kansas Department of Health and Environment.

${ }^{3}$ U.S. Army Corps of Engineers. or open water) had the highest microcystin concentrations. In July, the maximum microcystin concentration observed in each zone was detected at a nearshore site, and in August, maximum microcystin concentrations in each zone were detected at an open-water site.

The Kansas Department of Health and Environment uses two guidance levels (a watch and a warning level) to issue recreational public-health advisories for CyanoHABs in Kansas lakes. The levels are based on concentrations of microcystin and numbers of cyanobacteria. In July and August, discrete water-quality samples were predominantly indicative of warning status in Zone $\mathrm{C}$, watch status in Zone $\mathrm{B}$, and no advisories in Zone A. Regression-estimated microcystin concentrations, which provided more thorough coverage of Milford Lake $(n=683-720)$ than discrete samples $(n=21-24)$, generally indicated the same overall pattern. Regardless of the individual agencies sampling approach, the overall public-health advisory status of each zone in Milford Lake was similar according to the Kansas Department of Health and Environment guidance levels.

\section{Introduction}

Problems associated with cyanobacterial harmful algal blooms (CyanoHABs) include reductions in water quality, accumulation of malodorous scums along shorelines, production of taste-and-odor compounds that cause unpalatable drinking water and fish flesh, and production of toxins potent enough to poison aquatic and terrestrial organisms. Cyanobacterial toxins (cyanotoxins) have been implicated in human illness and animal deaths in at least 43 States in the United States (Graham and others, 2016). Past several decades have seen an apparent world-wide increase in the occurrence of toxic CyanoHABs (O'Neil and others, 2012).

Humans are most frequently exposed to cyanotoxins through recreational activities. Many States, including Kansas, have established monitoring programs for recreational water bodies to protect public health (Graham and others, 2009). Milford Lake (fig. 1) has been under Kansas Department of Health and Environment (KDHE) CyanoHAB advisories and warnings every summer from 2011 through 2016 (Kansas Department of Health and Environment, 2016a; Kansas 

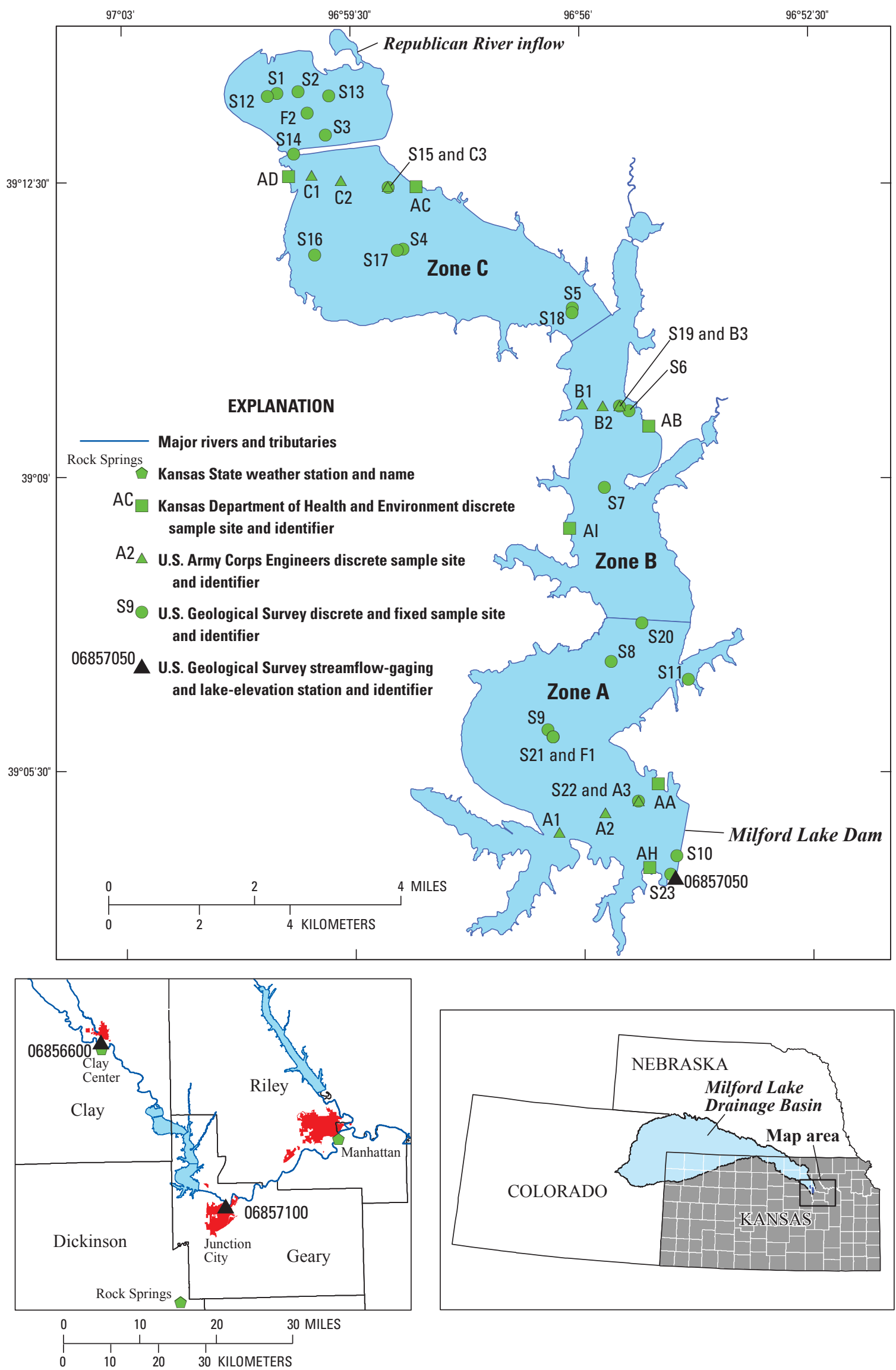

Figure 1. Milford Lake, including all study sites and zones used to issue public-health advisories. 
Department of Health and Environment, 2016b). Several dog deaths and human illnesses have been caused by CyanoHABs in Milford Lake (Trevino-Garrison and others, 2015).

The KDHE uses two guidance levels to issue recreational public-health advisories for CyanoHABs in Kansas lakes. The current (2016) guidance levels for public-health watches are cyanobacterial abundances ranging from 80,000 to 250,000 cells per milliliter (cells $/ \mathrm{mL}$ ) or microcystin, the most commonly present class of cyanotoxins, concentrations ranging from 4 to 20 micrograms per liter $(\mu \mathrm{g} / \mathrm{L})$. Cyanobacterial abundances or microcystin concentrations greater than or equal to $250,000 \mathrm{cells} / \mathrm{mL}$ and $20 \mu \mathrm{g} / \mathrm{L}$, respectively, are the current (2016) guidance levels for public-health warnings (Kansas Department of Health and Environment, 2015).

CyanoHABs tend to be spatially variable vertically in the water column and horizontally across the lake surface because of in-lake and weather-driven processes and can vary by orders of magnitude in concentration across relatively short distances (meters or less) (Graham and others, 2008). Extreme spatial variability in cyanobacteria and associated compounds poses unique challenges to collecting representative samples for scientific study and public-health protection. A comparison of sample-collection techniques and approaches and quantitative spatial assessments of CyanoHAB distribution will enhance understanding of CyanoHABs not only in Milford Lake but nationally.

\section{Purpose and Scope}

The purpose of this report is to present the results of a U.S. Geological Survey (USGS) study to assess the spatial variability of cyanobacteria and microcystin in Milford Lake using spatially dense near-surface data collected by the USGS, nearshore data collected by the KDHE, and open-water data collected by the U.S. Army Corps of Engineers (USACE). Combined, these data were used to characterize the magnitude and variability of cyanobacterial abundance and microcystin concentrations in Milford Lake. A better understanding of the spatial variability of cyanobacteria and microcystin will inform sampling and management strategies for Milford Lake as well as other lakes with CyanoHAB issues throughout the Nation.

\section{Description of Study Area}

Milford Lake is a reservoir that was completed in 1967 by the USACE for the purposes of flood control, water supply, water quality, navigation, recreation, and wildlife (Kansas Water Office, 2012) and is the largest lake in Kansas (fig. 1). The Milford Lake conservation pool has a surface area of about 63 square kilometers, a maximum depth of about 20 meters (m), an average depth of about $7.6 \mathrm{~m}$, and a conservation pool storage of 460 cubic hectometers $\left(\mathrm{hm}^{3}\right)$. Milford
Lake has a drainage area of approximately 64,400 square kilometers. The Republican River is the primary inflow to Milford Lake and drains areas of Kansas, Nebraska, and Colorado.

Milford Lake has been assigned a total maximum daily load (TMDL) to reduce phosphorus and nitrogen loads into the lake that was developed by the KDHE to control eutrophication and low dissolved oxygen concentrations in the lake (Kansas Department of Health and Environment 2016c). Based on Carlson's Trophic State Index (Carlson, 1977), Milford Lake is characterized as fully eutrophic (Kansas Department of Health and Environment, 2013). In Milford Lake, the long-term (1990-2011) average total nitrogen concentration is 1.06 milligrams per liter $(\mathrm{mg} / \mathrm{L}$ ) (range from 0.66 to $1.37 \mathrm{mg} / \mathrm{L}$ ), the long-term (1975-2011) average total phosphorus concentration is $0.13 \mathrm{mg} / \mathrm{L}$ (range from 0.05 to $0.35 \mathrm{mg} / \mathrm{L}$ ), and the long-term (1989-2011) average Secchi depth is $1.6 \mathrm{~m}$ (range from 1.0 to $2.4 \mathrm{~m}$ ) (Kansas Department of Health and Environment, 2016d). Milford Lake has had confirmed CyanoHABs every summer since 2011 (Kansas Department of Health and Environment, 2016b).

KDHE divided Milford Lake into three zones for recreational monitoring (fig. 1) because CyanoHABs commonly are present in localized parts of the lake, which makes closing the entire lake unnecessary. Zones were determined on the basis of depth, width, lake orientation to prevailing winds, and shoreline characteristics (Kansas Department of Health and Environment, 2016d, 2016e). Zone C is the uplake zone, Zone B is the midlake zone, and Zone A is the downlake zone. The U.S. Army Corps of Engineers (2016a) has collected water-quality data from each zone April through August, annually, since 2006. Milford Lake occasionally undergoes weak stratification near the dam, at depths of approximately 8-10 meters (U.S. Army Corps of Engineers, 2016a). Milford Lake displays the longitudinal variability typical in reservoirs, with higher nutrient concentrations and turbidities uplake than downlake (Thornton and others, 1990). Based on U.S. Army Corps of Engineers (2016b) data, from 2006 through 2015, average total nitrogen concentration was 2.4 times higher and average total phosphorus concentration was 1.6 times higher in Zone $\mathrm{C}$ than in Zone A. Average turbidity was 15 times higher in Zone $\mathrm{C}$ than in Zone A during the same period. Average Secchi depth was 5 times deeper in Zone A than in Zone C.

\section{Methods}

Data collection was coordinated among the USGS, KDHE, and USACE on July 27 and August 31, 2015. Each agency collected samples according to their own objectives and methods on the same day in order to compare results. A combination of discrete water-quality samples (USGS, KDHE, and USACE) and fixed-site and spatially continuous water-quality data (USGS) were collected. All data are available through the USGS National Water Information System (http://dx.doi.org/10.5066/F7P55KJN) and in King and others (2016a, b, and c). 
The three weather stations that bracket Milford Lake (Rock Springs, Clay, and Manhattan; fig. 1) were used to describe air temperature, wind speed and direction, and rainfall the day before and the day of data collection; data from all three stations were averaged to describe general weather conditions (Kansas State University, 2016). Two USGS streamflow-gaging stations (USGS station 06856600, Republican River at Clay Center, Kans., and USGS station 06857100, Republican River at Junction City, Kans.) and one USGS lakeelevation gaging station (USGS station 06857050, Milford Lake near Junction City, Kans.) (fig. 1) were used to describe lake inflows and outflows, as well as elevation and storage volume of Milford Lake during July and August 2015. Streamflow and lake elevation were measured using standard USGS methods (Sauer and Turnipseed, 2010; Turnipseed and Sauer, 2010). Streamflow and lake elevation data were downloaded from the USGS National Water Information System (http:// dx.doi.org/10.5066/F7P55KJN).

\section{Discrete Sample Collection and Analysis}

Each agency collected a slightly different set of indicator parameters to quantify CyanoHAB conditions. Discrete water-quality samples collected by all three agencies were analyzed for total microcystin concentrations. Analysis of total microcystin concentration is typical because microcystin is indicative of potential maximum exposure if ingested or inhaled during recreational activities (Loftin and others, 2008). Samples collected by the USGS also were analyzed for chlorophyll. Samples collected by the KDHE and some samples collected by the USACE also were analyzed for phytoplankton abundance and community composition.

\section{U.S. Geological Survey Sampling and Analysis Methods}

The USGS discrete water-quality samples were collected from 23 open-water locations between 08:30 and 16:00 hours during July and August 2015. Sample locations were not predetermined and were selected to represent the range of cyanobacterial conditions in the lake based on visual cues and continuous water-quality monitor data, as well as to capture adequate spatial coverage of the lake. On July 27, 2015, 14 discrete water-quality samples were collected, and on August 31, 2015, 12 discrete water-quality samples were collected (fig 1; table 1). Following USGS methods, discrete water-quality samples were collected as near-surface grabs using a weighted bottle sampler (Lane and others, 2003) and using a wide-mouth 1-liter high-density polyethylene bottles (U.S. Geological Survey, variously dated). All samples were immediately processed in the field for total microcystin and chlorophyll analyses as described in Graham and others (2008) and Hambrook Berkman and Canova (2007), respectively. Processed samples were stored on ice in the dark until the sample arrived at the U.S. Geological Survey Kansas Water
Science Center laboratory, Lawrence, Kansas. Total microcystin and chlorophyll samples were kept frozen until analysis.

Total microcystin was analyzed by the USGS Organic Geochemistry Research Laboratory, Lawrence, Kans. Cyanobacterial cells were lysed by three sequential freeze-thaw cycles and then filtered using 0.7-micrometer syringe filters (Loftin and others, 2008; Graham and others, 2010). Abraxis enzyme-linked immunosorbent assays (ELISA) were used to measure microcystin (detection limit $0.1 \mu \mathrm{g} / \mathrm{L}$; congener independent). Laboratory quality-control checks on ELISA measurements included assessment of interassay variability, laboratory duplicates, and blind spiked samples. All qualitycontrol data were considered acceptable if within 28.3 percent relative standard deviation (RSD), calculated by dividing the standard deviation by the average and then multiplying that value by 100 (Zar, 1999), of average or expected values. A sequential field replicate was collected in August. The percent RSD between the replicates was 30 percent. The variability between the samples may have been caused by laboratory processing and analysis or field sample collection techniques. Variability in sequential field replicates may be substantial because of the natural spatial variation in near-surface cyanobacteria (Graham and others, 2008).

Chlorophyll, an indicator of algal biomass (Hambrook Berkman and Canova, 2007), was analyzed at the USGS Kansas Water Science Center, Lawrence, Kans. Chlorophyll (uncorrected for degradation products) was analyzed fluorometrically using a modification of U.S. Environmental Protection Agency Method 445.0 (Arar and Collins, 1997). Instead of acetone extraction, samples were extracted in heated ethanol (Sartory and Grobbelar, 1986) and the fluorometer was modified with a flow-through cell (Knowlton, 1984). Laboratory quality-control checks on chlorophyll measurements included assessment of interrun variability, laboratory duplicates, and blanks. All samples were analyzed in duplicate, and the results reported as an average of the two duplicates. All quality-control and duplicate sample data were considered acceptable if within 20 percent RSD. A sequential field replicate was collected in August. The percent RSD between the replicates was 5 percent.

\section{Kansas Department of Health and Environment Sampling and Analysis Methods}

Concurrent with the USGS sampling efforts, KDHE discrete water-quality samples were collected from six predetermined nearshore locations between 09:30 and 11:30 hours. The KDHE sample sites are at public access points, including beaches (KDHE sites $\mathrm{AA}, \mathrm{AB}, \mathrm{AD}, \mathrm{AI}$ ) and boat ramps (KDHE sites AC, AH) (fig. 1; table 1). Discrete waterquality samples were collected as near-surface grabs using a pole sampler and beaker following KDHE methods (Kansas Department of Health and Environment, 2015). Samples were stored on ice in the dark and processed as soon as possible after the samples arrived at the laboratory. All samples were processed for total microcystin and phytoplankton abundance 
Table 1. Milford Lake discrete water-quality sampling sites, including sampling agency, sample type, analyses, and dates sampled.

[Lk, lake; KS, Kansas; KDHE, Kansas Department of Health and Environment; MC, total microcystin; PHYTO, phytoplankton; USACE, U.S. Army Corps of Engineers; USGS, U.S. Geological Survey; FCWQ, fixed continuous water-quality site with no discrete sample data; Chl, chlorophyll]

\begin{tabular}{|c|c|c|c|c|c|c|}
\hline $\begin{array}{l}\text { Site identifier } \\
\text { (fig. 1, tables } \\
2 \text { and } 3 \text { ) }\end{array}$ & Site name & $\begin{array}{c}\text { U.S. Geological } \\
\text { Survey station } \\
\text { number }\end{array}$ & Site type & Agency & $\begin{array}{c}\text { Sample } \\
\text { analysis }\end{array}$ & Date(s) sampled \\
\hline \multicolumn{7}{|c|}{ Zone A } \\
\hline AA & Milford Lk, KS KDHE Site AA & 390540096541700 & Nearshore & KDHE & $\begin{array}{l}\text { MC, } \\
\text { PHYTO }\end{array}$ & $7 / 27 / 2015,8 / 31 / 2015$ \\
\hline $\mathrm{AH}$ & Milford Lk, KS KDHE Site AH & 390440096542100 & Nearshore & KDHE & $\begin{array}{l}\text { MC, } \\
\text { PHYTO }\end{array}$ & $7 / 27 / 2015,8 / 31 / 2015$ \\
\hline A1 & Milford Lk, KS USACE Site A1 & 390502096554500 & Open water & USACE & $\mathrm{MC}$ & $7 / 27 / 2015$ \\
\hline A2 & Milford Lk, KS USACE Site A2 & 390517096550400 & Open water & USACE & $\mathrm{MC}$ & $7 / 27 / 2015$ \\
\hline${ }^{1} \mathrm{~F} 1$ & Milford Lake, KS Fixed Site 1 & 391328097000500 & Open water & USGS & FCWQ & $7 / 27 / 2015,8 / 31 / 2015$ \\
\hline S10 & Milford Lake, KS Site 10 & 390449096535700 & Open water & USGS & $\mathrm{Chl}, \mathrm{MC}$ & 7/27/2015 \\
\hline S11 & Milford Lake, KS Site 11 & 390655096535300 & Nearshore & USGS & $\mathrm{Chl}, \mathrm{MC}$ & $7 / 27 / 2015$ \\
\hline S20 & Milford Lake, KS Site 20 & 390734096543800 & Open water & USGS & $\mathrm{Chl}, \mathrm{MC}$ & $8 / 31 / 2015$ \\
\hline S21 & Milford Lake, KS Site 21 & 390610096555500 & Open water & USGS & $\mathrm{Chl}, \mathrm{MC}$ & $8 / 31 / 2015$ \\
\hline S22 & Milford Lake, KS Site 23 & 390435096540200 & Open water & USGS & $\mathrm{Chl}, \mathrm{MC}$ & $8 / 31 / 2015$ \\
\hline S8 & Milford Lake, KS Site 8 & 390706096560000 & Open water & USGS & $\mathrm{Chl}, \mathrm{MC}$ & $7 / 27 / 2015$ \\
\hline S9 & Milford Lake, KS Site 9 & 390615096560000 & Open water & USGS & $\mathrm{Chl}, \mathrm{MC}$ & $7 / 27 / 2015$ \\
\hline A3 & Milford Lake, KS Site 22 & 390527096543400 & Open water & $\begin{array}{l}\text { USGS and } \\
\text { USACE }\end{array}$ & $\begin{array}{l}\text { Chl, MC, } \\
\text { PHYTO }\end{array}$ & $7 / 27 / 2015,8 / 31 / 2015$ \\
\hline \multicolumn{7}{|c|}{ Zone B } \\
\hline $\mathrm{AB}$ & Milford Lake, KS KDHE Site AB & 390955096544000 & Nearshore & KDHE & $\begin{array}{l}\text { MC, } \\
\text { РHYTO }\end{array}$ & $7 / 27 / 2015,8 / 31 / 2015$ \\
\hline AI & Milford Lake, KS KDHE Site AI & 390840096554800 & Nearshore & KDHE & $\begin{array}{l}\text { MC, } \\
\text { PHYTO }\end{array}$ & $7 / 27 / 2015,8 / 31 / 2015$ \\
\hline B1 & Milford Lake, KS USACE Site B1 & 391009096554200 & Open water & USACE & $\mathrm{MC}$ & $7 / 27 / 2015$ \\
\hline B2 & Milford Lake, KS USACE Site B2 & 391008096552300 & Open water & USACE & $\mathrm{MC}$ & $7 / 27 / 2015$ \\
\hline S6 & Milford Lake, KS Site 6 & 391005096545800 & Open water & USGS & $\mathrm{Chl}, \mathrm{MC}$ & $7 / 27 / 2015$ \\
\hline S7 & Milford Lake, KS Site 7 & 390910096551800 & Open water & USGS & Chl, MC & 7/27/2015 \\
\hline B3 & Milford Lake, KS Site 19 & 391008096550700 & Open water & $\begin{array}{r}\text { USGS and } \\
\text { USACE }\end{array}$ & $\begin{array}{l}\text { Chl, MC, } \\
\text { PHYTO }\end{array}$ & $7 / 27 / 2015,8 / 31 / 2015$ \\
\hline \multicolumn{7}{|c|}{ Zone C } \\
\hline $\mathrm{AC}$ & Milford Lake, KS KDHE Site AC & 391238096582300 & Nearshore & KDHE & $\begin{array}{l}\text { MC, } \\
\text { PHYTO }\end{array}$ & $7 / 27 / 2015,8 / 31 / 2015$ \\
\hline $\mathrm{AD}$ & Milford Lake, KS KDHE Site AD & 391242097002000 & Nearshore & KDHE & $\begin{array}{l}\text { MC, } \\
\text { PHYTO }\end{array}$ & $7 / 27 / 2015,8 / 31 / 2015$ \\
\hline $\mathrm{C} 1$ & Milford Lake, KS USACE Site C1 & 391243096595900 & Open water & USACE & $\mathrm{MC}$ & $7 / 27 / 2015$ \\
\hline $\mathrm{C} 2$ & Milford Lake, KS USACE Site C2 & 391240096593200 & Open water & USACE & MC & $7 / 27 / 2015$ \\
\hline${ }^{1} \mathrm{~F} 2$ & Milford Lake, KS Fixed Site 2 & 390610096555500 & Open water & USGS & FCWQ & $8 / 31 / 2015$ \\
\hline $\mathrm{S} 1$ & Milford Lake, KS Site 1 & 391340097003400 & Open water & USGS & $\mathrm{Chl}, \mathrm{MC}$ & $7 / 27 / 2015$ \\
\hline $\mathrm{S} 12$ & Milford Lake, KS Site 12 & 391338097004300 & Open water & USGS & $\mathrm{Chl}, \mathrm{MC}$ & $8 / 31 / 2015$ \\
\hline S13 & Milford Lake, KS Site 13 & 391340096594600 & Open water & USGS & $\mathrm{Chl}, \mathrm{MC}$ & $8 / 31 / 2015$ \\
\hline S14 & Milford Lake, KS Site 14 & 391251097001600 & Open water & USGS & $\mathrm{Chl}, \mathrm{MC}$ & $8 / 31 / 2015$ \\
\hline S16 & Milford Lake, KS Site 16 & 391147096595300 & Open water & USGS & $\mathrm{Chl}, \mathrm{MC}$ & $8 / 31 / 2015$ \\
\hline S17 & Milford Lake, KS Site 17 & 391152096583700 & Open water & USGS & $\mathrm{Chl}, \mathrm{MC}$ & $8 / 31 / 2015$ \\
\hline S18 & Milford Lake, KS Site 18 & 391113096555500 & Open water & USGS & Chl, MC & $8 / 31 / 2015$ \\
\hline S2 & Milford Lake, KS Site 2 & 391342097001500 & Open water & USGS & $\mathrm{Chl}, \mathrm{MC}$ & $7 / 27 / 2015$ \\
\hline S3 & Milford Lake, KS Site 3 & 391312096594800 & Open water & USGS & $\mathrm{Chl}, \mathrm{MC}$ & $7 / 27 / 2015$ \\
\hline S4 & Milford Lake, KS Site 4 & 391154096583200 & Open water & USGS & $\mathrm{Chl}, \mathrm{MC}$ & $7 / 27 / 2015$ \\
\hline S5 & Milford Lake, KS Site 5 & 391117096555400 & Open water & USGS & Chl, MC & 7/27/2015 \\
\hline $\mathrm{C} 3$ & Milford Lake, KS Site 15 & 391237096584800 & Open water & $\begin{array}{l}\text { USGS and } \\
\text { USACE }\end{array}$ & $\begin{array}{l}\text { Chl, MC, } \\
\text { PHYTO }\end{array}$ & $7 / 27 / 2015,8 / 31 / 2015$ \\
\hline
\end{tabular}

${ }^{1}$ Sensor-measured water-quality data were collected at these sites as part of this study. These data are not presented as part of the final analysis but are provided in King and others (2016c). 
and community composition analyses according to KDHE protocols (Kansas Department of Health and Environment, 2015). Total microcystin samples were stored frozen until analysis. Samples for phytoplankton abundance and community composition analysis were preserved with Lugol's iodine.

Total microcystin and phytoplankton abundance and community composition were analyzed by the KDHE (Kansas Department of Health and Environment, 2014). Cyanobacterial cells were lysed by one freeze-thaw cycle prior to total microcystin analysis. Envirologix ELISA QualiTubes were used according to manufacturer's specifications to measure total microcystin (detection limit $0.5 \mu \mathrm{g} / \mathrm{L}$ ); microcystin concentrations were quantitated using a spectrophotometer. The intra-assay RSD for measurement of microcystin-fortified control solutions for the Envirologix QualiTube assay is 8.1 percent; the inter-assay RSD is 9.6 percent (EnviroLogix, 2015). Phytoplankton were enumerated by counting 50 random fields within a modified Sedgwick-Rafter counting cell according to standard methods (American Public Health Association, 1992), with one modification. The sample concentration step was eliminated because most cyanobacterial bloom samples require dilution before counting can be done properly.

\section{U.S. Army Corps of Engineers Sampling and Analysis Methods}

The USACE discrete water-quality samples were collected from open-water locations as near-surface grabs between 10:30 and 13:30 hours. On July 27, 2015, samples were collected from nine predetermined open-water locations along three transects selected based on a nearshore KDHE sample location in each zone (KDHE AA, sites A1, A2; AB, sites B1, B2, B3; and AC, sites C2, C3; fig. 1; table 1). Transects were selected to facilitate comparisons of microcystin concentrations at the KDHE nearshore sample location with open-water microcystin concentrations in the same part of the lake. Each transect had three sample locations-one on the eastern side of the lake, one in the center of the lake, and one on the western side of the lake (fig. 1). The sample bottles from two transect locations (A3 and C1; fig. 1; table 1) broke during shipping; therefore, microcystin data from these two sites are missing. On August 31, 2015, samples were collected from the three offshore locations closest to the KDHE sampling site in each zone (KDHE AA, AB, and AC; fig. 1). Near-surface grab samples were collected using a 1-liter highdensity polyethylene bottle on a Nasco Swing Sampler following USGS methods (Graham and others, 2008). Samples were stored on ice in the dark and processed as soon as possible after the samples arrived at the laboratory. All samples were processed for total microcystin analysis according to USACE protocols (U.S. Army Corps of Engineers, 2003). Samples collected from the offshore locations closest to the KDHE sampling sites also were processed for phytoplankton abundance and community composition. Phytoplankton samples were preserved with Lugol's iodine.
Total microcystin and phytoplankton abundance and community composition were analyzed by BSA Environmental Services, Inc., Beachwood, Ohio. Cyanobacterial cells were lysed by three sequential freeze-thaw cycles prior to microcystin analysis using a 1-mL subsample and then filtered using 0.45 -micrometer syringe filters. The Abraxis ELISA was used according to manufacturer's specifications to measure microcystin (detection limit $0.1 \mu \mathrm{g} / \mathrm{L}$; congener independent). Laboratory quality-control checks on ELISA measurements include blanks, quality-control standards, and laboratory duplicates. Quality-control standards were considered acceptable if the RSD was less than or equal to 10 percent. Laboratory duplicates were considered acceptable if the RSD was within 20 percent.

Phytoplankton were enumerated to the lowest possible taxonomic level using membrane-filtered slides (McNabb, 1960). A minimum of 400 natural units (colonies, filaments, and unicells) were counted from each sample; in accordance with Lund and others (1958), counting 400 natural units provides accuracy within 90 percent confidence limits. In addition, an entire strip of the filter was counted at high magnification (usually 630X) along with one-half of the filter at a lower magnification (usually $400 \mathrm{X}$ ) to ensure complete species reporting.

\section{Spatial Data Collection}

Spatial data were collected using boat-mounted waterquality monitors during July 27, 2015, and August 31, 2015, between 08:30 and 16:00 hours. Multiparameter water-quality monitors were mounted underneath the boat at about 0.5 - and $1.5-\mathrm{m}$ depths (hereinafter referred to as the top sensor and the bottom sensor, respectively), and a nitrate sensor (HACH Nitratax plus sc sensor) was mounted at about 1.0-m depth (fig. 2). Boat speed was approximately 14 kilometers per hour, which provided the best balance of data quality and the ability to complete a representative survey of the lake in a timely manner. To capture variability at fixed-site locations during the survey, spatial data collection buoys with multiparameter water-quality monitors at about $1.0-\mathrm{m}$ depths were deployed. On July 27, 2015, a buoy was placed in Zone A (fig. 1; "F1"), and on August 31, 2015, buoys were placed in Zones A and C (fig. 1; "F1" and "F2").

Multiparameter water-quality monitors (YSI EXO2; Yellow Springs Instruments Inc., 2016) recorded temperature, specific conductance, turbidity, $\mathrm{pH}$, dissolved oxygen, chlorophyll (fluorescence), and phycocyanin (fluorescence). Boat-mounted sensors, including the nitrate sensor, recorded data at 30-second intervals; fixed-site location sensors recorded data at 15-minute intervals. The centralized wipers on the boat-mounted multiparameter and nitrate monitors were programmed to wipe every 5 minutes; the centralized wiper on the fixed-site location monitor was programmed to wipe before every measurement. All sensors were calibrated prior to each deployment in accordance with USGS protocols (U.S. 


\section{$\boldsymbol{A}$}

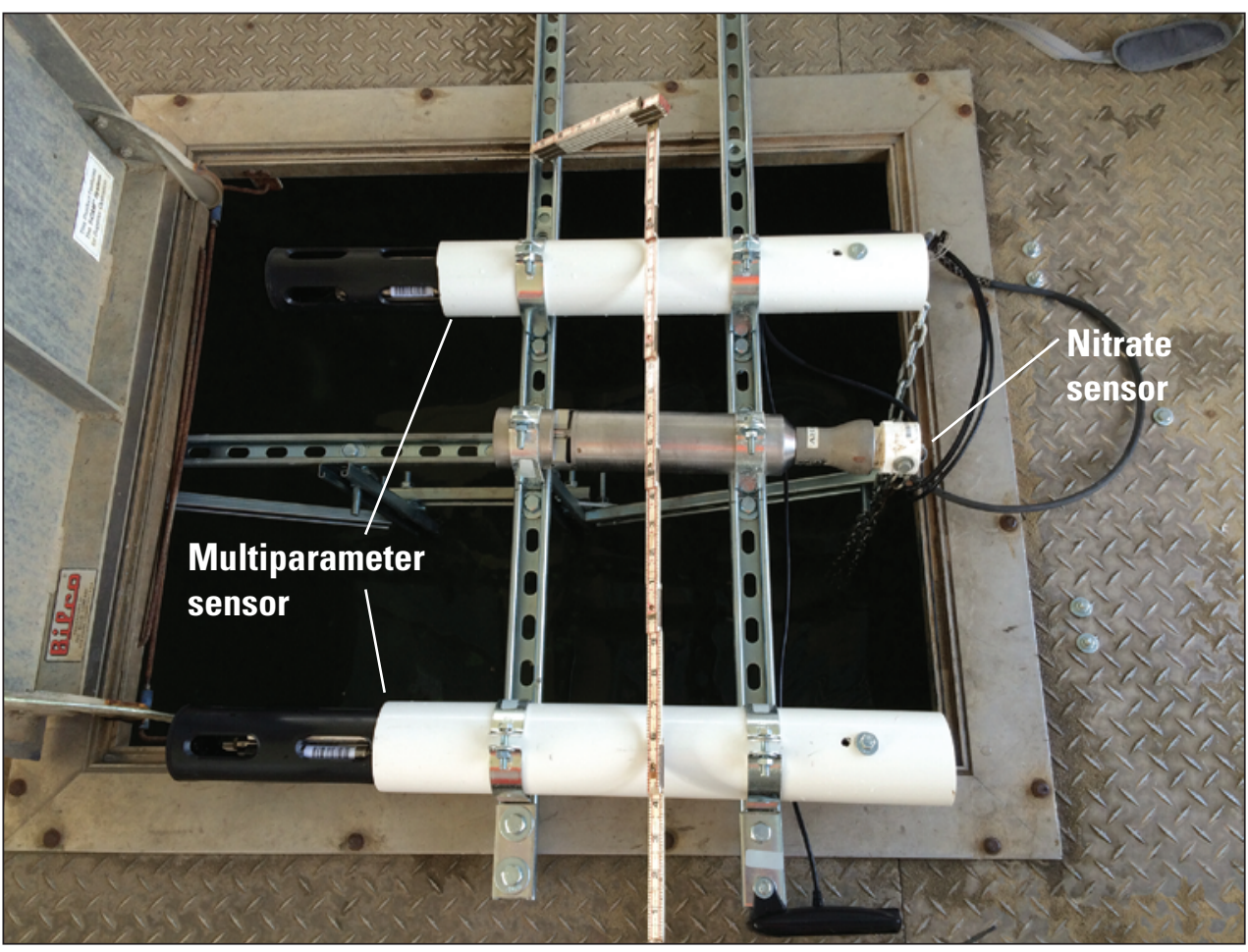

$\boldsymbol{B}$

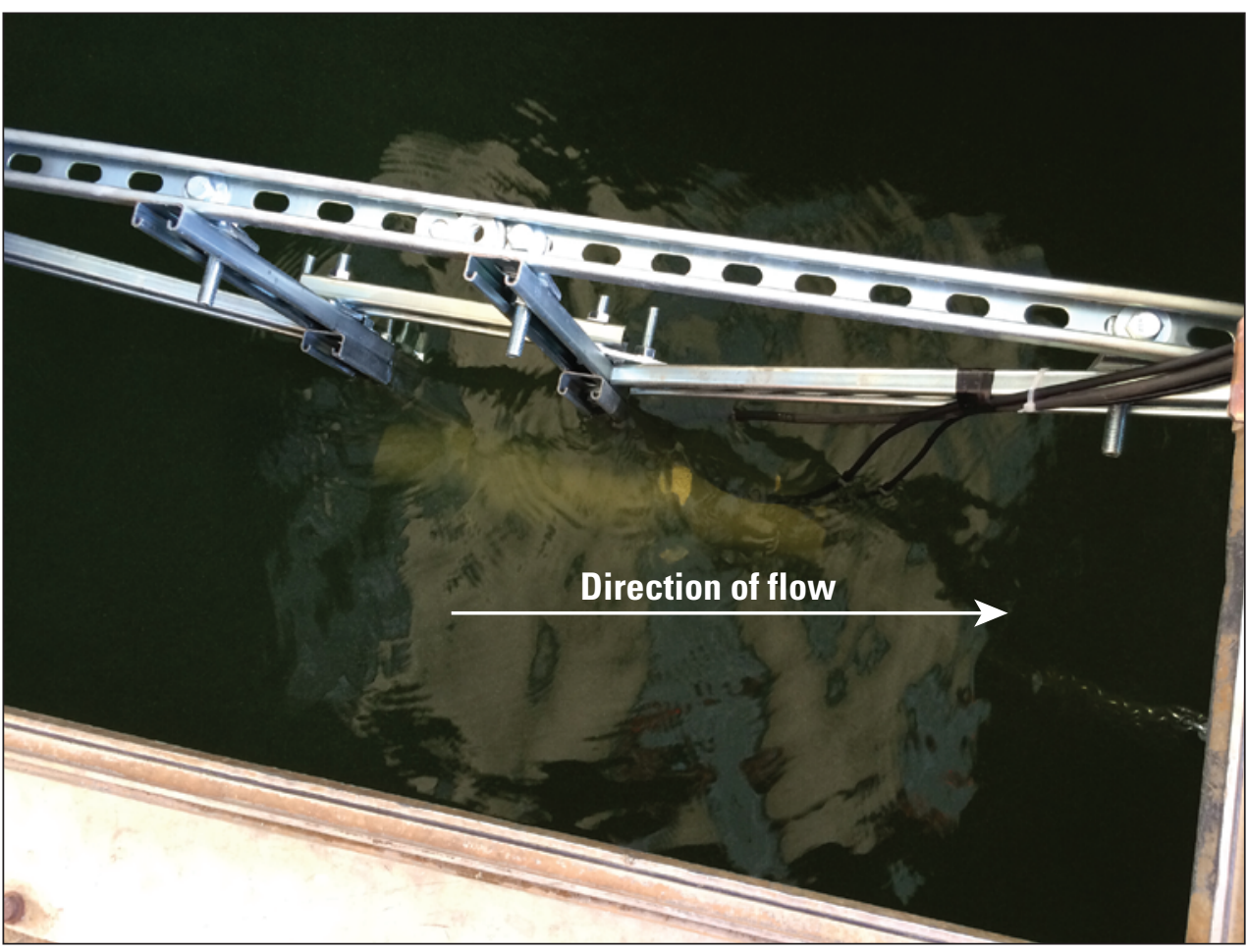

Figure 2. Mounted sensor-array used for spatial data collection. $A$, predeployed boat mounted multiparameter sensors (top and bottom) and nitrate sensor (middle) and $B$, sensor-array mounted and deployed under the boat. 
Geological Survey, variously dated; Pellerin and others, 2013). The boat location was recorded using a global positioning system (GPS; Garmin Montana 650T) recording every 30 seconds. All data loggers had their time synchronized at the beginning of data collection events.

This report uses the spatial chlorophyll and phycocyanin data reported in relative fluorescence units (RFU) from the mounted-sensor array. Chlorophyll and phycocyanin data are reported in RFU because these sensors were calibrated to a secondary standard (Rhodamine Water Tracing), not primary chlorophyll and phycocyanin standards. In addition, these data were used to develop regression models for laboratorymeasured chlorophyll (used as a surrogate for cyanobacteria in this analysis) and laboratory-measured total microcystin; RFU is recommended when developing relations between sensor-measured fluorescence and laboratory-measured chlorophyll (Yellow Springs Instruments Inc., 2016). Because the fixed-site location data and other parameters either were not directly relevant to the analysis or were not valid explanatory variables, only the phycocyanin RFU data from the mountedsensor array were used in the final analysis. All spatial and fixed-site location water-quality data collected as part of this study are available in King and others (2016b and c).

\section{Data Analysis}

Statistical differences in total microcystin concentrations among zones in Milford Lake were tested using the nonparametric Kruskal-Wallis one-way analysis of variance on ranks followed by the Dunn's test for multiple comparisons (Sokal and Rohlf, 1995). Statistical differences in total microcystin concentrations at near-shore and open-water locations were tested using the nonparametric Mann-Whitney rank sum test (Sokal and Rohlf, 1995). Significance for these analyses was set at a probability value ( $p$-value) of less than 0.05 .

Ordinary least-squares analysis (Helsel and Hirsch, 2002) was used to develop regression models between top-sensor measured chlorophyll and phycocyanin RFU and laboratorymeasured chlorophyll and total microcystin concentrations. For comparison with discrete-sample data, top-sensor measured chlorophyll and phycocyanin RFU values were averaged during a 3-minute period using the minute before, the minute of, and the minute after the recorded discrete-sample collection time. Data collected during July 27, 2015, and August 31, 2015, were combined for regression analysis. Because discrete samples were collected just below the water surface and the top sensor was at a depth of $0.5-\mathrm{m}$, this approach assumes that the relation between sensor-measured chlorophyll and phycocyanin RFU, laboratory-measured chlorophyll, and total microcystin does not change within the $0.5-\mathrm{m}$ change in depth.

There was a linear association between top-sensor measured chlorophyll RFU and laboratory-measured chlorophyll and microcystin, but models only explained 65 and 52 percent of the variance in laboratory-measured chlorophyll and total microcystin concentrations, respectively. By comparison, a strong linear association was indicated between top-sensor measured phycocyanin RFU and laboratory-measured chlorophyll and total microcystin concentrations (fig. 3). Phycocyanin RFU from the top sensor explained 93 and 91 percent of the variance in laboratory-measured chlorophyll and total microcystin concentrations, respectively, as indicated by the coefficient of determination $\left(R^{2}\right)$. Chlorophyll and phycocyanin are algal pigments that are maintained intracellularly. All photosynthetic organisms, including algae and cyanobacteria, contain chlorophyll; however, the phycocyanin pigment is indicative of cyanobacteria (Hambrook Berkman and Canova, 2007). Phycocyanin may have been a better explanatory variable for laboratory-measured chlorophyll and total microcystin concentrations during this study because the algal community in Milford Lake was almost exclusively cyanobacteria.

Chlorophyll and total microcystin concentrations in Milford Lake at depths of 0.5 and $1.5 \mathrm{~m}$ were estimated by using phycocyanin RFU data collected with the mounted sensor array and with the regression models developed using phycocyanin RFU data and laboratory-measured concentrations. Details of the regression models used to estimate chlorophyll and microcystin concentrations are presented in appendixes 1 and 2. Applying the regression models to the phycocyanin RFU data collected at $1.5 \mathrm{~m}$, assumes that the relation between sensor-measured phycocyanin RFU, laboratory-measured chlorophyll, and total microcystin is the same as the relation developed for $0.5 \mathrm{~m}$.

Regression estimated values of chlorophyll were negative for phycocyanin values less than $0.2 \mathrm{RFU}$, and regression estimated values of microcystin were negative for phycocyanin values less than $0.76 \mathrm{RFU}$; therefore, estimated chlorophyll concentrations at $0.2 \mathrm{RFU}$ and estimated microcystin concentrations at $0.76 \mathrm{RFU}$ were used as the minimum reporting thresholds for estimated data. The minimum reporting threshold for estimated chlorophyll and microcystin concentrations was $0.02 \mu \mathrm{g} / \mathrm{L}$. Because of the focus on bloom conditions and the wide range of concentrations detected in Milford Lake during this study, the lack of sensitivity of these models at low phycocyanin RFU values does not substantially affect observed spatial patterns in chlorophyll and microcystin; however, these regression models are specific to the spatial data collected during this study and cannot be applied to the fixedsite data collected as part of this study, other data collected from Milford Lake, or data collected from other lakes.

Statistical differences in estimated chlorophyll and microcystin concentrations with depth in Milford Lake were tested using the nonparametric Mann-Whitney rank sum test (Sokal and Rohlf, 1995). Statistical differences in estimated chlorophyll and microcystin concentrations among zones in Milford Lake were tested using the nonparameteric KruskalWallis one-way analysis of variance on ranks followed by the Dunn's test for multiple comparisons (Sokal and Rohlf, 1995). Significance for these analyses was set at a probability value ( $p$-value) of less than 0.05 .

Maps of estimated chlorophyll and microcystin concentrations in Milford Lake were generated from the 

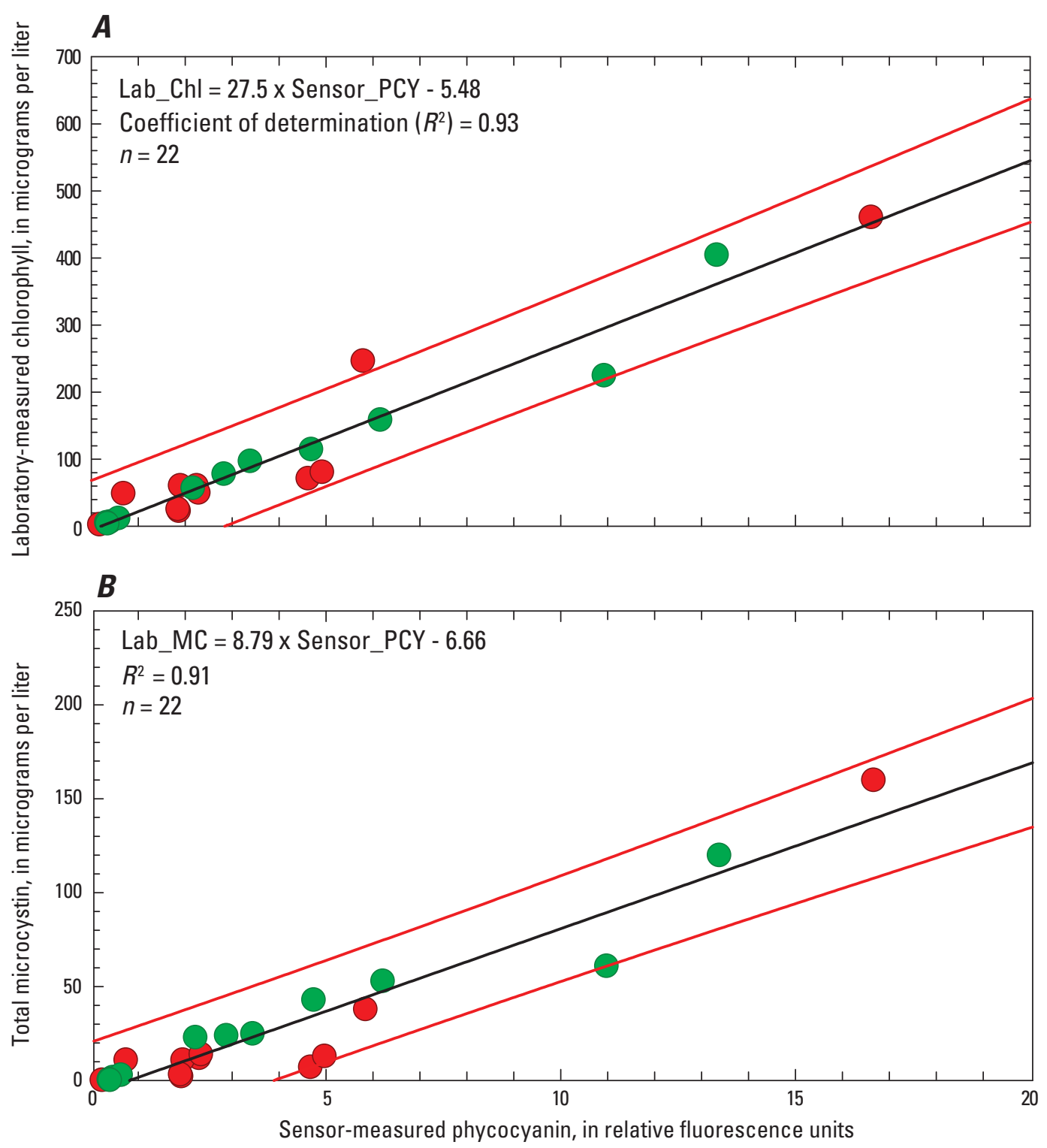

EXPLANATION

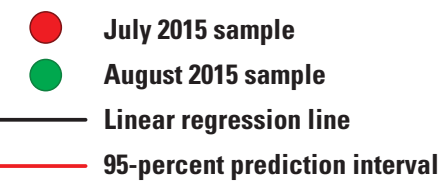

Figure 3. Comparison between top-sensor measured phycocyanin and laboratory-measured chlorophyll and total microcystin. $A$, the phycocyanin-chlorophyll comparison and $B$, the phycocyaninmicrocystin comparison. 
spatial-survey data using ArcGIS (version 10.3.1). Data were interpolated between points using the "Topo to Raster" tool in the "3-D Analyst Toolbox." The data points used the projected coordinate system "NAD_1983_2011_UTM_Zone_14N," and the Milford Lake boundary data from the National Hydrography Dataset (http://nhd.usgs.gov/index.html). Maps were created in pairs to represent the two depths at which data were collected. In each paired-map figure, five natural class breaks were used to interpolate the data. To maintain the same scale for both maps for comparison, the class breaks for the map with the greatest range were applied to both maps.

\section{Interlaboratory Comparison}

Microcystin was the only constituent analyzed by all three agencies collecting data for the study. The laboratories were compared to evaluate among-laboratory differences in microcystin analysis. On August 31, 2015, split-replicate samples were collected by each agency. Each agency collected one split-replicate sample per zone. The USGS and USACE collected split-replicate samples at sites $\mathrm{C} 3, \mathrm{~B} 3$, and A3; the KDHE collected split-replicate samples at sites AC, AB, and AA (fig. 1; table 1). Samples were collected using agency protocols and then split into three aliquots. Each sample was gently mixed by inversion before pouring off individual aliquots. Each aliquot was then analyzed by the USGS, KDHE, and USACE laboratories. The samples collected by the KDHE were not analyzed by the USGS laboratory.

The reporting precision for microcystin measured by ELISA of the USGS and USACE laboratories is plus or minus 20 percent; the KDHE does not report precision for microcystin analysis using the Envirologix ELISA QualiTube because it is a semiquantitative approach. The percent RSDs between split-replicate samples when all values were above the method minimum reporting level (MRL) ranged from 20 to 58 percent (median, 29 percent; $n=8$ ). About one-half of comparison RSDs were larger than the reporting precision of 20 percent for the USGS and USACE laboratories. The MRLs for the USGS and USACE methods were $0.1 \mu \mathrm{g} / \mathrm{L}$, and the MRL for the KDHE method was $0.5 \mu \mathrm{g} / \mathrm{L}$. Because of this difference in MRL, one sample had a detection by the USACE method $(0.45 \mu \mathrm{g} / \mathrm{L})$ but did not have a detection by the KDHE method (less than $0.5 \mu \mathrm{g} / \mathrm{L}$ ). Overall microcystin concentrations in the interlaboratory comparison dataset ranged from less than 0.5 to $488 \mu \mathrm{g} / \mathrm{L}$ (median: $16.3 \mu \mathrm{g} / \mathrm{L}, n=24$ ). Absolute differences in microcystin concentrations between split-replicate samples ranged from 0.1 to $158 \mu \mathrm{g} / \mathrm{L}$ (median: $4.1 \mu \mathrm{g} / \mathrm{L}$, $n=20$ ). In general, the split-replicate samples with the largest RSDs and absolute differences in concentration were also the samples with the highest microcystin concentrations (fig. 4). In most split-replicate sample groups ( 89 percent), measured microcystin concentrations were indicative of the same KDHE public-health advisory status, regardless of differences in measured microcystin concentrations (fig. 4).

More than 80 known microcystin congeners have been reported (Loftin and others, 2016). The function of the
ELISA's was based on preferential antibody binding to target chemicals on the basis of their chemical structure and the sample matrix. Calibration of the ELISAs used in this study are based on microcystin-LR, which is one of the more commonly observed microcystin congeners. The ELISAs report a summed concentration of reactive congeners based on this reactivity (for example, cross-reactivity). Each manufacturer's ELISA has different cross-reactivity and can result in vastly different responses for the same samples unless the samples are dominated by microcystin-LR. Typically, as congener composition increases in complexity, results from different ELISAs agree to a lesser extent (Loftin and others, 2008). The cross-reactivity of the Abraxis ELISA used by the USACE and USGS laboratories is more uniform across the microcystin congeners (3-amino-9-methoxy-2,6,8-trimethyl-10-phenyldeca-4,6-dienoic acid [ADDA]-specific), compared to the Envirologix ELISA used by the KDHE laboratory, which is more specific to microcystin-LR by design.

Three sample preparation approaches and two ELISAs were used to analyze microcystin as part of this study. No consistent pattern was indicated in the difference in the measured microcystin concentrations among laboratories, indicating that the among-laboratory differences in cyanobacteria cell-lysis techniques or the ELISA used for analysis did not cause a consistent bias. Differences among split-replicate samples may be attributed to method variation or congener complexity in samples, or both. All samples in this study were dominated by Microcystis, which is fairly easy to lyse by the freeze-thaw process. In this study, all laboratories lysed cyanobacterial cells using freeze-thaw, but the number of freeze-thaw cycles ranged from one to three. Additional comparisons using cyanobacteria that are more difficult to lyse, such as sheathbearing filamentous cyanobacteria, are warranted.

\section{Results for July 27, 2015}

Air temperatures averaged between 28.1 and 28.8 degrees Celsius during July 26-27, 2015. Winds were generally from the south and southeast, with average wind speeds between 1.6 and 2.1 meters per second. Small amounts of rainfall were recorded at all three weather stations during July 26-27, 2015, with totals ranging from 0.25 to 0.76 millimeters.

The average lake elevation on July 27, 2015, was $349.5 \mathrm{~m}$ (almost 1 meter above the conservation pool elevation of $348.8 \mathrm{~m}$ ). To assess lake conditions prior to spatial surveys, inflow, outflow, and lake storage data for the week prior (July $20-27,2015)$ were analyzed. Inflows ranged from 12.7 to 174 cubic meters per second $\left(\mathrm{m}^{3} / \mathrm{s}\right)$ and averaged $35.9 \mathrm{~m}^{3} / \mathrm{s}$. A large inflow event occurred on July 21, 2015 (maximum streamflow $174 \mathrm{~m}^{3} / \mathrm{s}$ ), and a second, smaller event occurred on July 26, 2015 (maximum streamflow $20 \mathrm{~m}^{3} / \mathrm{s}$ ). During July 20 through July 27, 2015, lake outflows ranged from 14.4 to $16.8 \mathrm{~m}^{3} / \mathrm{s}$ (average $15.2 \mathrm{~m}^{3} / \mathrm{s}$ ), lake storage ranged from 490 to $510 \mathrm{hm}^{3}$, and average water residence time was 388 days. 


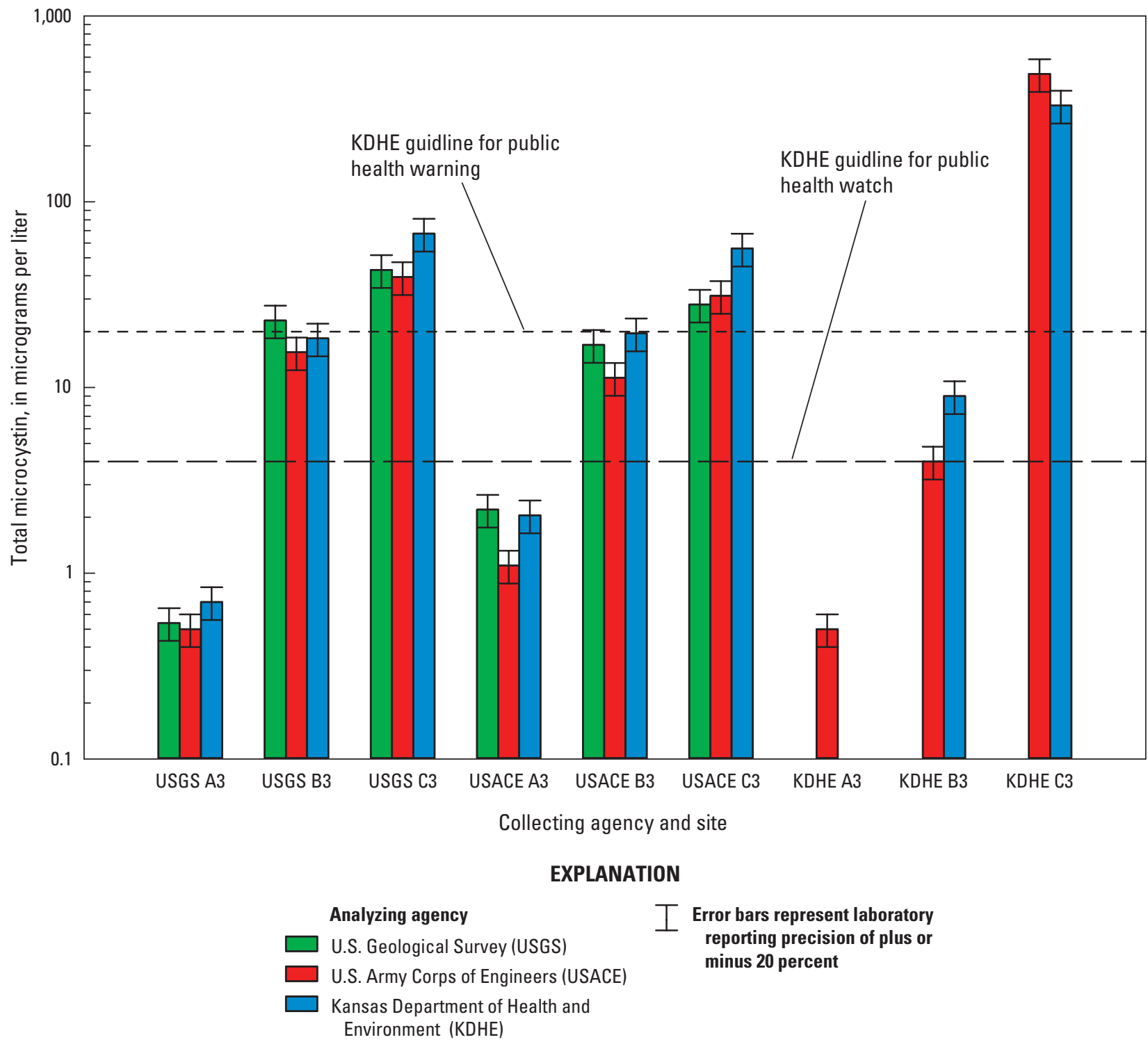

Figure 4. Comparison of total microcystin concentrations in split-replicate samples collected by the U.S. Geological Survey, Kansas Department of Health and Environment, and U.S. Army Corps of Engineers.

\section{Discrete Sample Results}

The phytoplankton community in Milford Lake on July 27, 2015, was almost exclusively (greater than 90 percent of total phytoplankton abundance) cyanobacteria. The cyanobacterial community was predominantly the known microcystinproducer Microcystis and Aphanizomenon, which is not a documented microcystin producer (Graham and others, 2008). Cyanobacterial abundance ranged from 32,000 cells $/ \mathrm{mL}$ in a nearshore area of Zone A to $4,900,000$ cells $/ \mathrm{mL}$ in a nearshore area of Zone $\mathrm{C}$ (table 2). In Zones $\mathrm{C}$ and $\mathrm{B}$, cyanobacterial abundances in nearshore areas exceeded the KDHE warning threshold of 250,000 cells $/ \mathrm{mL}$, and the KDHE watch threshold of between 80,000 and 250,000 cells $/ \mathrm{mL}$ was exceeded in open-water areas. In Zone A, one nearshore location exceeded the watch threshold, and a nearshore and an offshore location were below the watch threshold (less than 80,000 cells $/ \mathrm{mL}$ ).

Based on data collected by all three agencies, microcystin concentrations in Milford Lake ranged from 0.21 to $300 \mu \mathrm{g} / \mathrm{L}$, on July 27, 2015 (median, $9.2 \mu \mathrm{g} / \mathrm{L} ; n=24$; table 2; fig. 5). Median microcystin concentration in Zone C (38 $\mu \mathrm{g} / \mathrm{L}$, $n=9)$ was about 22 times higher than in Zone A $(1.7 \mu \mathrm{g} / \mathrm{L}$, $n=8)$ and about 5 times higher than in Zone B $(7.3 \mu \mathrm{g} / \mathrm{L}, n=7)$. Although median microcystin concentrations decreased in the downlake direction, only the difference between Zones $\mathrm{C}$ and A was statistically significant (Dunn's $Q$-statistic [ $Q$-statistic], 3.71; $p$-value, less than 0.001). Overall, nearshore samples $(14 \mu \mathrm{g} / \mathrm{L}, n=7)$ had a median microcystin concentration nearly 
Table 2. Total microcystin concentration and cyanobacterial abundance in discrete water-quality samples collected by the U.S. Geological Survey, the Kansas Department of Health and Environment, and the U.S. Army Corps of Engineers on July 27, 2015.

$[\mu \mathrm{g} / \mathrm{L}$, microgram per liter; KDHE, Kansas Department of Health and Environment; cells/mL, cells per milliliter; USACE, U.S. Army Corps of Engineers; --, not measured; USGS, U.S. Geological Survey]

\begin{tabular}{|c|c|c|c|c|c|c|}
\hline Agency & $\begin{array}{c}\text { Site } \\
\text { identifier }\end{array}$ & Site type & $\begin{array}{c}\text { Microcystin } \\
(\mu \mathrm{g} / \mathrm{L})\end{array}$ & $\begin{array}{c}\text { KDHE } \\
\text { advisory }^{1}\end{array}$ & $\begin{array}{c}\text { Cyanobacteria } \\
\text { (cells/mL) }\end{array}$ & KDHE advisory \\
\hline \multicolumn{7}{|c|}{ Zone C } \\
\hline KDHE & $\mathrm{AC}$ & Nearshore & 300 & Warning & $4,900,000$ & Warning \\
\hline KDHE & $\mathrm{AD}$ & Nearshore & 100 & Warning & $3,600,000$ & Warning \\
\hline USACE & $\mathrm{C} 1$ & Open water & -- & -- & -- & -- \\
\hline USACE & $\mathrm{C} 2$ & Open water & 30 & Warning & -- & -- \\
\hline USACE & $\mathrm{C} 3$ & Open water & 88 & Warning & 190,000 & Watch \\
\hline USGS & $\mathrm{S} 1$ & Open water & 38 & Warning & -- & -- \\
\hline USGS & $\mathrm{S} 2$ & Open water & 7.2 & Watch & -- & -- \\
\hline USGS & $\mathrm{S} 3$ & Open water & 160 & Warning & -- & -- \\
\hline USGS & $\mathrm{S} 4$ & Open water & 13 & Watch & -- & -- \\
\hline USGS & S5 & Open water & 11 & Watch & -- & -- \\
\hline \multicolumn{7}{|c|}{ Zone B } \\
\hline KDHE & AI & Nearshore & 55 & Warning & $1,300,000$ & Warning \\
\hline KDHE & $\mathrm{AB}$ & Nearshore & 6.0 & Watch & 560,000 & Warning \\
\hline USACE & B1 & Open water & 2.9 & None & -- & -- \\
\hline USACE & B2 & Open water & 5.5 & Watch & 81,000 & Watch \\
\hline USACE & B3 & Open water & 7.3 & Watch & -- & -- \\
\hline USGS & S6 & Open water & 12 & Watch & -- & -- \\
\hline USGS & S7 & Open water & 11 & Watch & -- & -- \\
\hline \multicolumn{7}{|c|}{ Zone A } \\
\hline KDHE & AA & Nearshore & 4.0 & Watch & 140,000 & Watch \\
\hline KDHE & $\mathrm{AH}$ & Nearshore & 1.0 & None & 32,000 & None \\
\hline USACE & A1 & Open water & 0.32 & None & -- & -- \\
\hline USACE & $\mathrm{A} 2$ & Open water & 0.38 & None & -- & -- \\
\hline USACE & A3 & Open water & -- & -- & 64,000 & None \\
\hline USGS & S8 & Open water & 2.3 & None & -- & -- \\
\hline USGS & S9 & Open water & 3.3 & None & -- & -- \\
\hline USGS & $\mathrm{S} 10$ & Open water & 0.21 & None & -- & -- \\
\hline USGS & $\mathrm{S} 11$ & Nearshore & 14 & Watch & -- & -- \\
\hline
\end{tabular}

${ }^{1}$ Based on Kansas Department of Health and Environment criteria for issuing public health advisories (Kansas Department of Health and Environment, 2015).

twice that of open-water samples $(7.3 \mu \mathrm{g} / \mathrm{L}, n=17)$; however, this difference was not statistically significant (Mann-Whitney $U$-statistic [ $U$-statistic], 42; $p$-value, 0.508). Although maximum microcystin concentrations were consistently observed at a near-shore location in all zones, microcystin concentrations at near-shore locations were not consistently greater than at open-water locations. For example, a maximum microcystin concentration of $55 \mu \mathrm{g} / \mathrm{L}$ was detected at one of the nearshore locations (AI) in Zone B, whereas the second nearshore location $(\mathrm{AB})$ had microcystin concentrations within the range observed at open-water sites. A similar pattern was noted in Zone A (fig. 5; table 2). The general location of the highest nearshore concentrations was inconsistent throughout the lake. Microcystin concentrations were higher on the eastern shore of the lake in Zones C and A. In Zone B, microcystin concentrations were higher at the site on the western shore of the lake (fig. 5).

The USACE collected open-water samples along three transects selected based on a nearshore KDHE sample location in each zone (KDHE AA, $\mathrm{AB}$, and $\mathrm{AC}$; fig. 1; table 1). In 


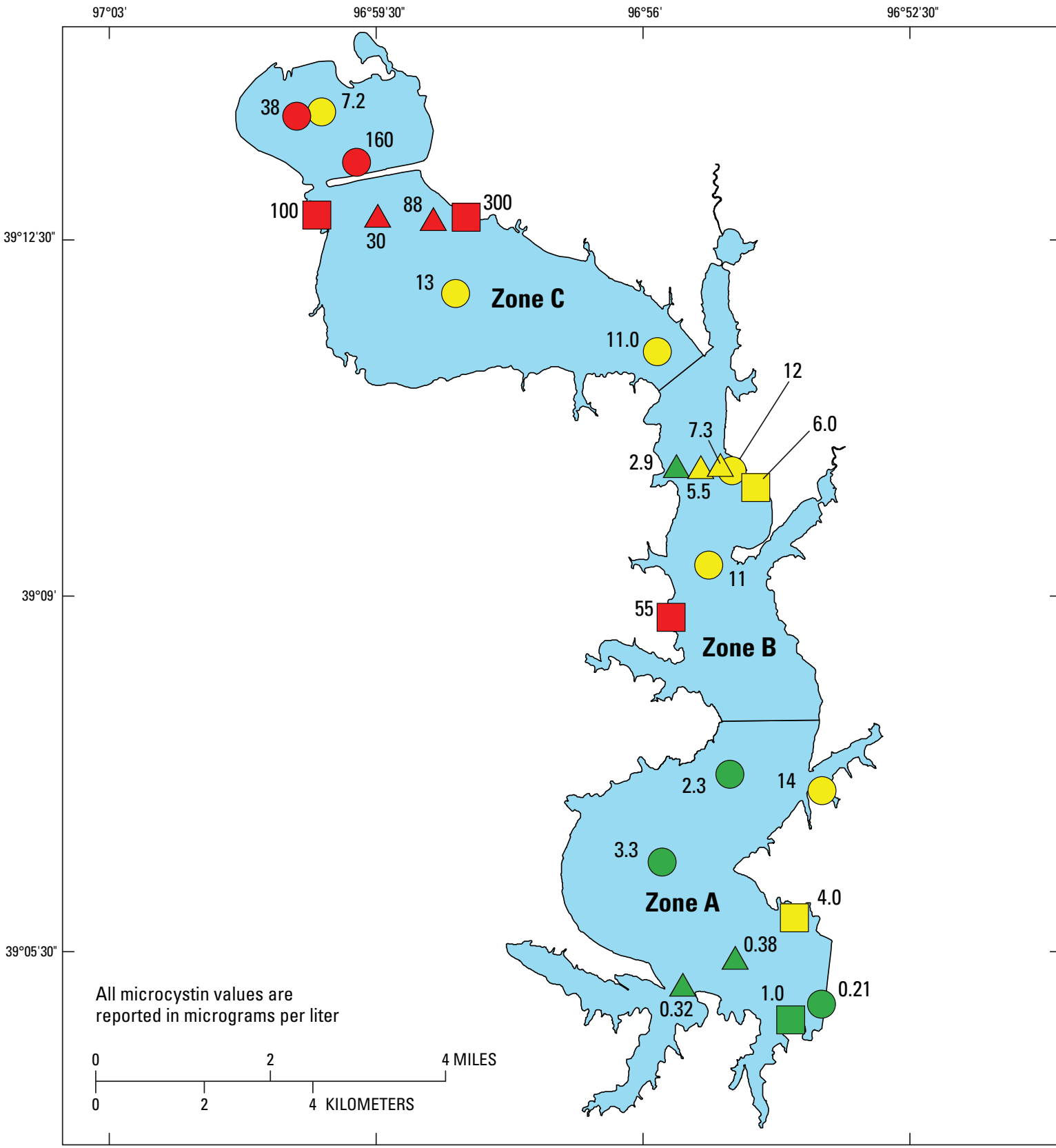

EXPLANATION

U.S. Geological Survey sample site

No advisory, 0 to $<4$ micrograms per liter

Watch, 4 to 20 micrograms per liter

Warning, $>20$ micrograms per liter

\section{Kansas Department of Health and} Environment sample site

No advisory, 0 to $<4$ micrograms per liter

Watch, 4 to 20 micrograms per liter

Warning, $>20$ micrograms per liter

\section{U.S. Army Corps of Engineers sample site}
$\triangle$ No advisory, 0 to $<4$ micrograms per liter
$\triangle$ Watch, 4 to 20 micrograms per liter
Warning, $>20$ micrograms per liter

Figure 5. Total microcystin concentration in discrete water-quality samples collected by the U.S. Geological Survey, the Kansas Department of Health and Environment, and the U.S. Army Corps of Engineers on July 27, 2015. 
Zone $\mathrm{C}$, microcystin concentrations varied by about three-fold across the transect (30-88 $\mu \mathrm{g} / \mathrm{L})$ and were 3-10 times less than concentrations at the proximate nearshore location $(300 \mu \mathrm{g} / \mathrm{L})$. In Zone B, microcystin concentrations varied by more than two-fold across the transect $(2.9-7.3 \mu \mathrm{g} / \mathrm{L})$ and ranged from 2 times less than to generally similar to the proximate near-shore location $(6 \mu \mathrm{g} / \mathrm{L})$. Microcystin concentrations did not vary substantially across the transect in Zone A $(0.32$ $0.38 \mu \mathrm{g} / \mathrm{L})$ and were about 11 times less than the proximate nearshore location $(4 \mu \mathrm{g} / \mathrm{L})$ (fig. 5 ; table 2$)$.

Regardless of the sampling location or approach used, 71 percent of microcystin concentrations exceeded either the KDHE warning threshold of $20 \mu \mathrm{g} / \mathrm{L}$ ( 29 percent) or the KDHE watch threshold of between 4 and $20 \mu \mathrm{g} / \mathrm{L}$ (42 percent) on July 27, 2015. Twenty-nine percent of concentrations were less than the $4 \mu \mathrm{g} / \mathrm{L}$ threshold for issuing a public-health advisory. In Zone C, 67 percent of microcystin concentrations exceeded the KDHE warning threshold, and the remaining 33 percent exceeded the KDHE watch threshold. Fourteen percent of Zone B microcystin concentrations exceeded the warning threshold, 72 percent exceeded the watch threshold, and 14 percent were less than the watch threshold. In Zone B, the site with a concentration below the watch threshold was in an open-water area (fig. 5). Only 25 percent of Zone A microcystin concentrations exceeded the watch threshold; sites with concentrations below the watch threshold were in open-water and nearshore areas (fig. 5).

\section{Spatial Survey Results}

Chlorophyll is commonly used as an estimate of algal biomass (Hambrook Berkman and Canova, 2007). Regressionestimated chlorophyll concentrations were used to describe the distribution of algal biomass at $0.5-$ and $1.5-\mathrm{m}$ depths in Milford Lake on July 27, 2015. Estimated chlorophyll concentrations at $0.5-\mathrm{m}$ depth in Milford Lake ranged from less than 0.02 to $730 \mu \mathrm{g} / \mathrm{L}$, with a median estimated concentration of $39 \mu \mathrm{g} / \mathrm{L}(n=683)$. At $1.5-\mathrm{m}$ depth, estimated concentrations ranged from less than 0.02 to $890 \mu \mathrm{g} / \mathrm{L}$, with a median estimated concentration of $40 \mu \mathrm{g} / \mathrm{L}$ ( $n=683$ ) (table 3 ). Overall, estimated chlorophyll concentrations were not significantly different between the two depths ( $U$-statistic, 228540; $p$-value, 0.519), however, estimated chlorophyll concentrations were significantly different between the two depths in Zone A. Although the difference in median concentrations was small, estimated chlorophyll concentrations at $1.5-\mathrm{m}$ depth (median, $20 \mu \mathrm{g} / \mathrm{L}$ ) were significantly higher than at $0.5-\mathrm{m}$ depth (median, $16 \mu \mathrm{g} / \mathrm{L}$ ) ( $U$-statistic, 23402; $p$-value, 0.004) in Zone A. Differences with depth in Zone C ( $U$-statistic, 45087; $p$-value, 0.184 ) and Zone B ( $U$-statistic, $9254 ; p$-value, 0.687 ) were not statistically significant. Estimated chlorophyll concentrations were indicative of higher algal biomass uplake, with decreases in the downlake direction (fig. 6). At 0.5- and 1.5 -m depths, median estimated chlorophyll concentrations were about 5 times higher in Zone $\mathrm{C}$ than in Zone $\mathrm{A}$ and about 2 times higher than in Zone B. Estimated chlorophyll concentrations in Zone B were about 2 times higher than in Zone A. Also, greater variability in estimated chlorophyll concentrations was indicated uplake than downlake. In Zone C, estimated concentrations had a range of $885 \mu \mathrm{g} / \mathrm{L}$, compared to $132 \mu \mathrm{g} / \mathrm{L}$ in Zone B and $71 \mu \mathrm{g} / \mathrm{L}$ in Zone A (figs. $7 A$, $7 C$; table 3 ). These among-zone differences in estimated chlorophyll concentrations were statistically significant (all $Q$-statistics greater than 6; all $p$-values less than 0.001).

Regression-estimated microcystin concentrations were used to describe the distribution of microcystin at 0.5 - and 1.5- $\mathrm{m}$ depths in Milford Lake on July 27, 2015. Estimated microcystin concentrations at $0.5-\mathrm{m}$ depth in Milford Lake ranged from less than 0.02 to $230 \mu \mathrm{g} / \mathrm{L}$, with a median estimated concentration of $7.7 \mu \mathrm{g} / \mathrm{L}(n=683)$ (table 3$)$. At $1.5-\mathrm{m}$ depth, estimated concentrations ranged from less than 0.02 to $280 \mu \mathrm{g} / \mathrm{L}$, with a median estimated concentration of $7.9 \mu \mathrm{g} / \mathrm{L}$ $(n=683)$ (table 3). Patterns with depth and among zones were

Table 3. Summary statistics for regression estimated chlorophyll and total microcystin concentrations in Milford Lake on July 27, 2015.

[m, meter; $n$, number of samples; \pm , plus or minus; PI, 95-percent prediction interval; $<$, less than]

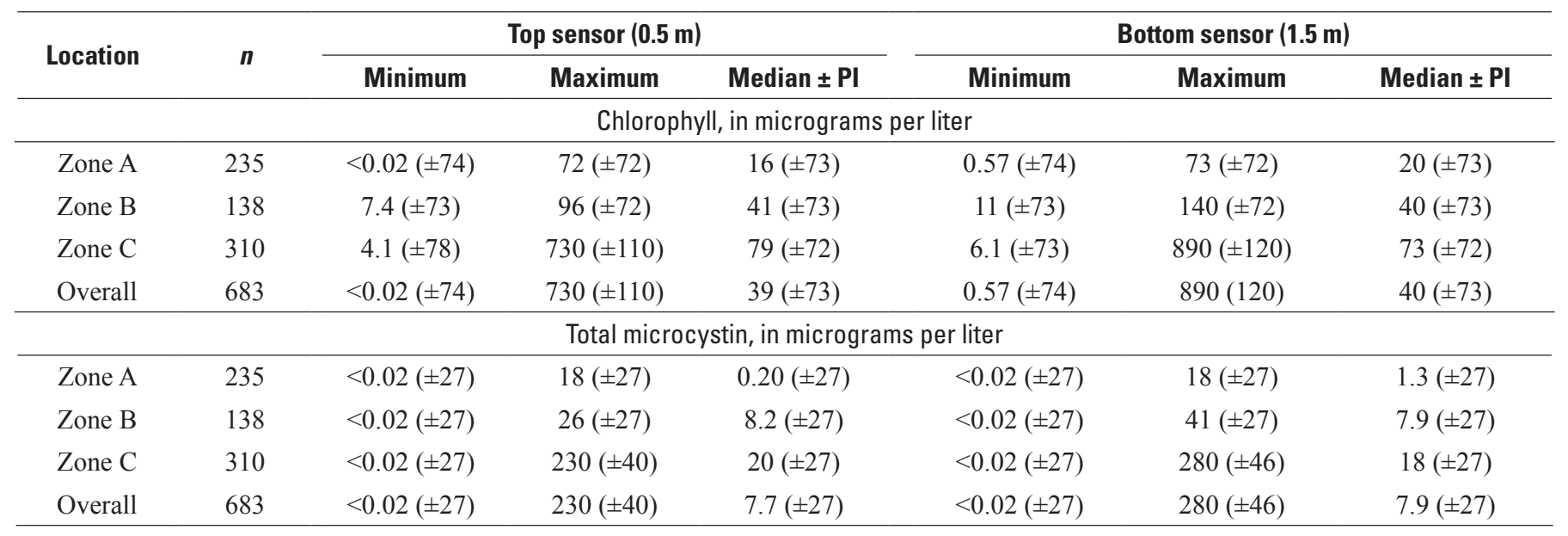



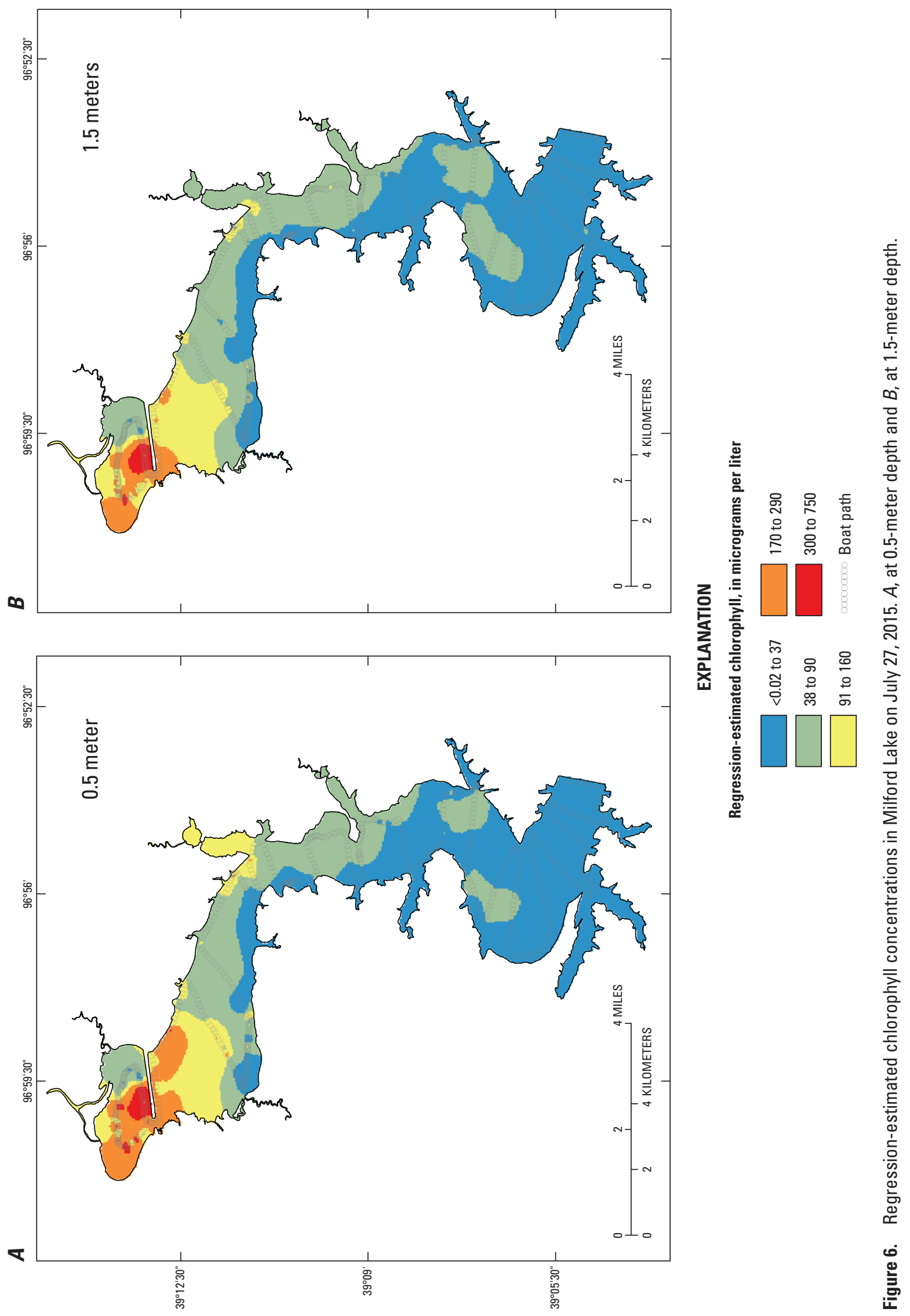

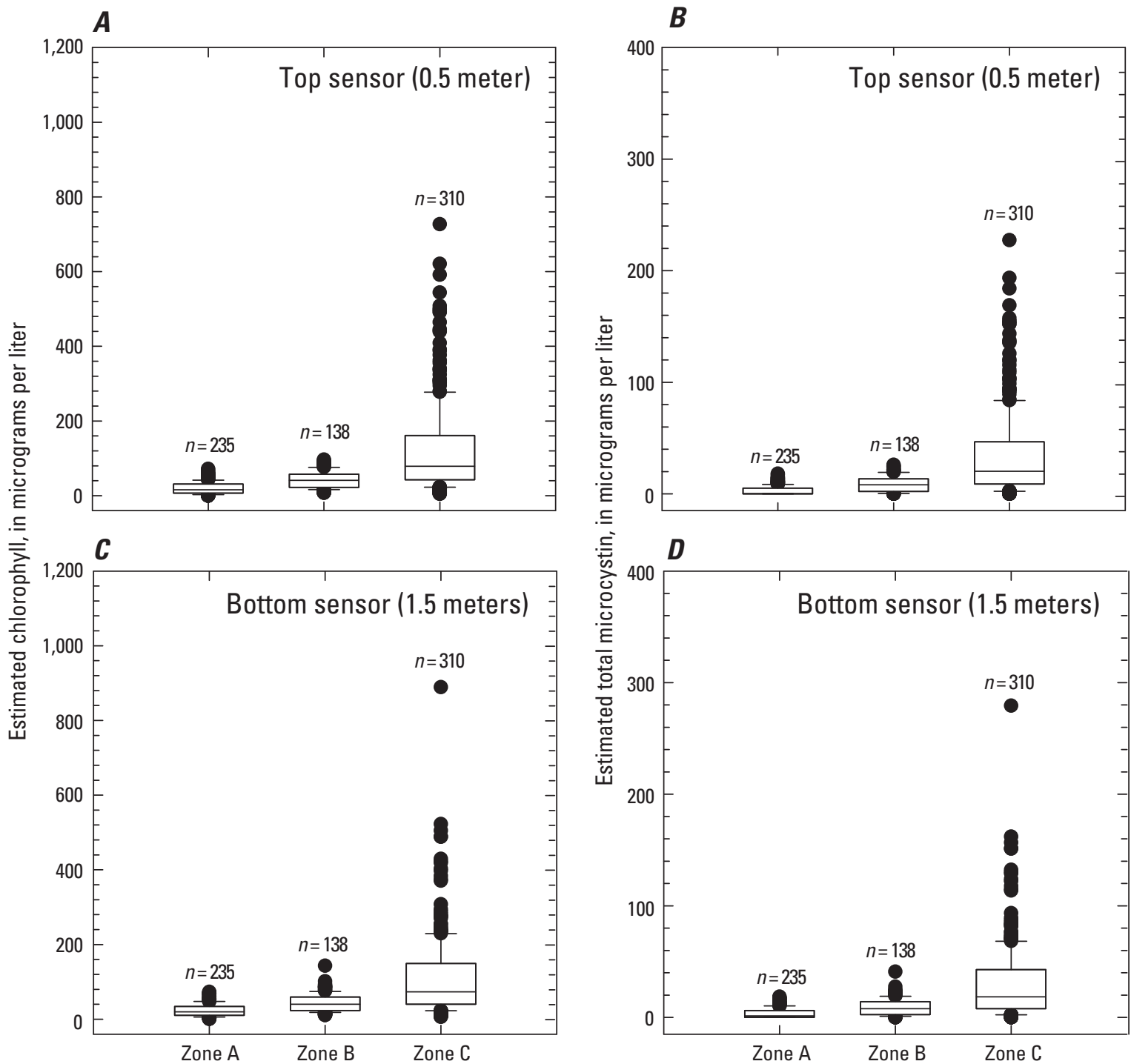

EXPLANTION

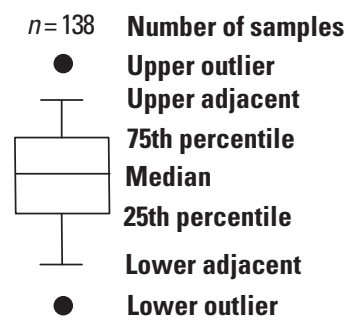

Figure 7. Box plots of regression-estimated chlorophyll and total microcystin concentrations in Milford Lake Zones $\mathrm{A}, \mathrm{B}$, and $\mathrm{C}$ on July 27, 2015. $A$, estimated chlorophyll at 0.5 -m depth; $B$, estimated total microcystin at 0.5-m depth; $C$, estimated chlorophyll at 1.5-m depth; and $D$, estimated total microcystin at 1.5-m depth. 

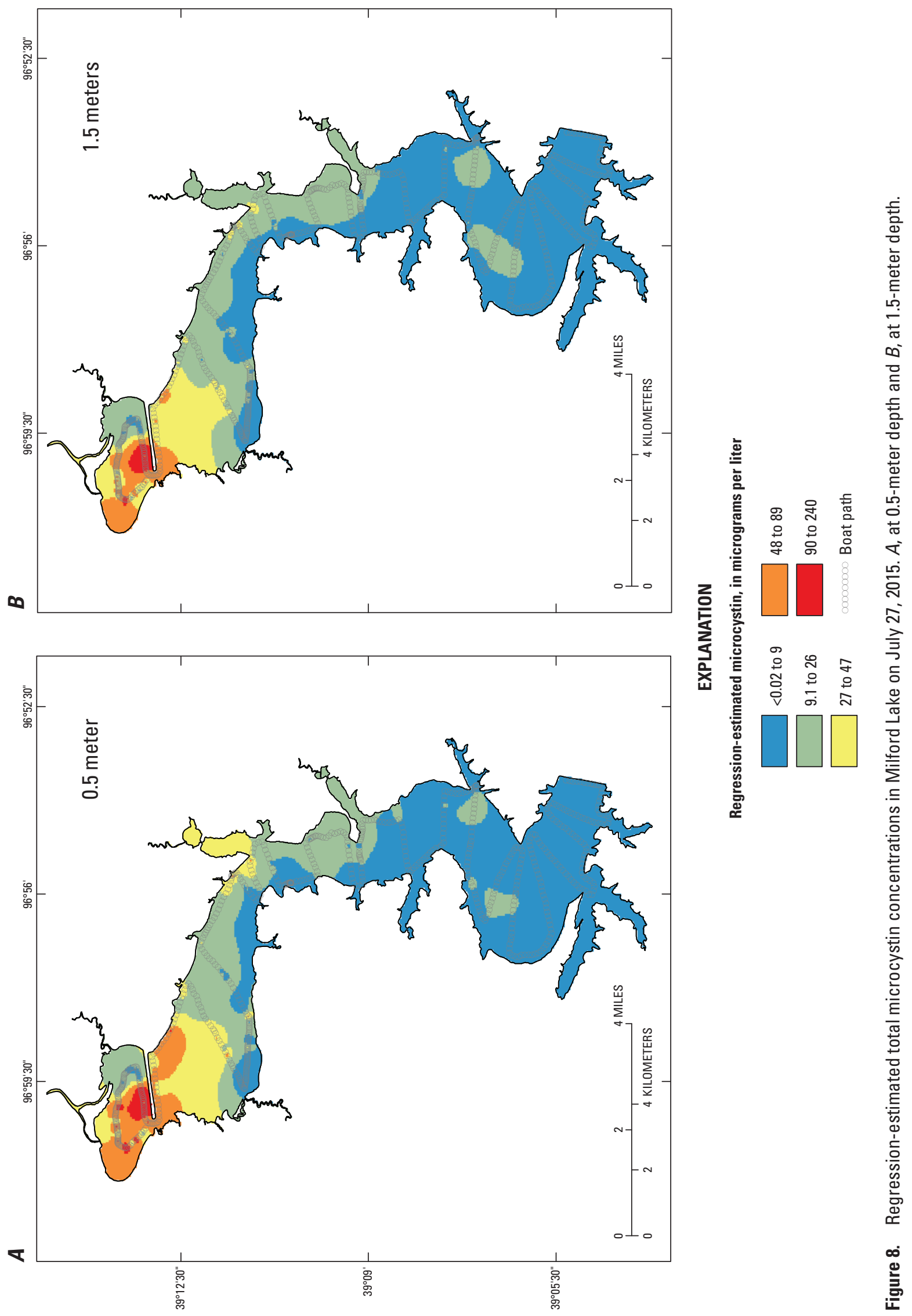
similar to patterns in estimated chlorophyll concentrations (figs. 6-8). Overall, differences in estimated microcystin concentrations between depths were not significant ( $U$-statistic, 230380; $p$-value, 0.693). Estimated microcystin concentrations were significantly higher at $1.5-\mathrm{m}$ depth $(1.3 \mu \mathrm{g} / \mathrm{L})$ than at 0.5 -m depth $(0.20 \mu \mathrm{g} / \mathrm{L})$ in Zone A ( $U$-statistic, 24631 ; $p$-value, 0.034$)$ but not in Zone C ( $U$-statistic, 45071; $p$-value, 0.182$)$ or in Zone B (U-statistic, 9288; $p$-value, $0.725)$. The median estimated microcystin concentration was about 100 times higher at $0.5-\mathrm{m}$ depth and 14 times higher at 1.5-m depth in Zone $\mathrm{C}$ than in Zone $\mathrm{A}$ and about 2.5 higher in Zone $\mathrm{C}$ than in Zone $\mathrm{B}$ at both depths. Also, greater variability in estimated microcystin concentrations was determined uplake than downlake. Estimated microcystin concentrations in Zone $\mathrm{C}$ had a much wider range (about $280 \mu \mathrm{g} / \mathrm{L}$ ) than in Zones B and A (about 18-41 $\mu \mathrm{g} / \mathrm{L}$ ) (figs. 7B, 7D; table 3). These among-zone differences in estimated microcystin concentrations were statistically significant (all $Q$-statistics greater than 6; all $p$-values less than 0.001).

Regression-estimated microcystin concentrations were compared to KDHE thresholds for public-health advisories. The percentage of estimated concentrations in each category was similar at the $0.5-$ and $1.5-\mathrm{m}$ depths, and all data are described together. Based on estimated microcystin concentrations, about 25 percent of estimated values $(n=1,366)$ were above the KDHE warning threshold of $20 \mu \mathrm{g} / \mathrm{L}$. About 40 percent of estimated microcystin concentrations were above the watch threshold of $4 \mu \mathrm{g} / \mathrm{L}$, and about 35 percent of estimated concentrations were below $4 \mu \mathrm{g} / \mathrm{L}$. Patterns in public-health advisory status among zones reflect the uplake to downlake pattern in estimated microcystin concentrations (fig. 6). In Zone $\mathrm{C}(n=310)$, about 50 percent of estimated microcystin concentrations were above the warning threshold and about 35 percent were above the watch threshold. About 10 percent of estimated microcystin concentrations were above the warning threshold and 60 percent were above the watch threshold in Zone B ( $n=138)$. By comparison, about 65 percent of the estimated microcystin concentrations in Zone A $(n=235)$ were less than $4 \mu \mathrm{g} / \mathrm{L}$; about 30 percent were above the watch threshold and none of the estimated concentrations were above the warning threshold (figs. $7 B, 7 D$; table 3 ).

\section{Results for August 31, 2015}

Air temperatures averaged between 22.1 and 23.0 degrees Celsius during August 30-31, 2015. Winds were variable on the day prior to the spatial survey (August 30,2015) but were steady from the southeast on the day of the spatial survey (August 31, 2015), with average wind speeds from 2.4 to 2.5 meters per second. Trace amounts of rainfall were recorded at the Rock Springs and Clay weather stations (about 0.25 millimeter) on the morning of August 30, 2015.

The average lake elevation on August 31, 2015 (349.4 $\mathrm{m}$ ), was similar to the elevation during the July data collection event. Inflow, outflow, and lake storage data were analyzed for the week prior (August 24-31, 2015) to assess lake conditions prior to spatial surveys. Inflows ranged from 7.8 to $10.6 \mathrm{~m}^{3} / \mathrm{s}$, and averaged $9.3 \mathrm{~m}^{3} / \mathrm{s}$. No large inflow events occurred during the week prior to the spatial survey. Lake outflows during this period ranged from 15.3 to $17.0 \mathrm{~m}^{3} / \mathrm{s}$ (average $15.9 \mathrm{~m}^{3} / \mathrm{s}$ ). Lake storage from July 20 through July 27, 2015, was steady, averaging $510 \mathrm{hm}^{3}$, and average residence time was 368 days.

\section{Discrete Sample Results}

As observed in July, the phytoplankton community in Milford Lake on August 31, 2015, was almost exclusively (greater than 90 percent of total phytoplankton abundance) cyanobacteria. Unlike July, the cyanobacterial community was overwhelmingly dominated (greater than 95 percent) by Microcystis. Cyanobacterial abundance ranged from 4,700 cells $/ \mathrm{mL}$ in a nearshore area of Zone A to $1,000,000$ cells $/ \mathrm{mL}$ in an open-water area of Zone C (table 4). In Zone C, cyanobacterial abundances at nearshore and open-water areas met or exceeded the KDHE warning threshold of 250,000 cells $/ \mathrm{mL}$ (table 4). In Zone B, the open-water area had a cyanobacterial abundance above the KDHE watch threshold. All nearshore areas in Zone B and all areas in Zone A had cyanobacterial abundances below the watch threshold (less than 80,000 cells $/ \mathrm{mL}$ ) (table 4).

Based on data collected by all three agencies, microcystin concentrations on August 31,2015, ranged from less than 0.50 to $380 \mu \mathrm{g} / \mathrm{L}$ (median, $23 \mu \mathrm{g} / \mathrm{L} ; n=21$ ) (table 4, fig. 9). As observed in July, microcystin concentrations decreased in the downlake direction. The median microcystin concentration in Zone C $(52 \mu \mathrm{g} / \mathrm{L}, n=10)$ was about 95 times higher than in Zone $\mathrm{A}(0.54 \mu \mathrm{g} / \mathrm{L}, n=7)$ and about 3.5 times higher than in Zone B $(15 \mu \mathrm{g} / \mathrm{L}, n=4)$; only the difference between Zones C and A was statistically significant ( $Q$-statistic, 4.09; $p$-value, less than 0.001). Overall, open-water samples ( $24 \mu \mathrm{g} / \mathrm{L}, n=15)$ had a median microcystin concentration of about 1.7 times that of near-shore samples ( $14 \mu \mathrm{g} / \mathrm{L}, n=6)$ (table 4 , fig. 9); however, this difference was not statistically significant ( $U$-statistic, 36; $p$-value, 0.508). Although the maximum microcystin concentrations in each zone were observed in open-water areas, microcystin concentrations at near-shore locations were generally within the range observed at open-water sites for that zone.

On August 31, 2015, regardless of the sampling location approach used, 67 percent of microcystin concentration either exceeded the KDHE warning threshold of $20 \mu \mathrm{g} / \mathrm{L}$ (52 percent) or were within the KDHE watch threshold (14 percent), and 33 percent of microcystin concentrations were less than the watch threshold. In Zone $\mathrm{C}$, all microcystin concentrations exceeded the KDHE warning threshold. In Zone B, 25 percent of microcystin concentrations exceeded the warning threshold, and 75 percent were within the watch threshold. In Zone A, all microcystin concentrations were below $4 \mu \mathrm{g} / \mathrm{L}$. 
Table 4. Total microcystin concentration and cyanobacterial abundance in discrete water-quality samples collected by the U.S. Geological Survey, the Kansas Department of Health and Environment, and the U.S. Army Corps of Engineers on August 31, 2015.

[ $\mu \mathrm{g} / \mathrm{L}$, microgram per liter; KDHE, Kansas Department of Health and Environment; cells/mL, cells per milliliter; USACE, U.S. Army Corps of Engineers; USGS, U.S. Geological Survey; --, not measured]

\begin{tabular}{|c|c|c|c|c|c|c|}
\hline Agency & $\begin{array}{c}\text { Site } \\
\text { identifier }\end{array}$ & Site type & $\begin{array}{c}\text { Microcystin } \\
\text { ( } \mu \mathrm{g} / \mathrm{L})\end{array}$ & $\begin{array}{c}\text { KDHE } \\
\text { advisory }^{1}\end{array}$ & $\begin{array}{c}\text { Cyanobacteria } \\
\text { (cells/mL) }\end{array}$ & KDHE advisory \\
\hline \multicolumn{7}{|c|}{ Zone C } \\
\hline KDHE & $\mathrm{AC}$ & Nearshore & 330 & Warning & 830,000 & Warning \\
\hline KDHE & $\mathrm{AD}$ & Nearshore & 50 & Warning & 250,000 & Warning \\
\hline USACE & $\mathrm{C} 3$ & Open water & 31 & Warning & $1,000,000$ & Warning \\
\hline USGS & $\mathrm{S} 12$ & Open water & 61 & Warning & -- & -- \\
\hline USGS & S13 & Open water & 25 & Warning & -- & -- \\
\hline USGS & S14 & Open water & 120 & Warning & -- & -- \\
\hline USGS & S16 & Open water & 380 & Warning & -- & -- \\
\hline USGS & S17 & Open water & 53 & Warning & -- & -- \\
\hline USGS & S18 & Open water & 24 & Warning & -- & -- \\
\hline USGS & $\mathrm{C} 3$ & Open water & 43 & Warning & -- & -- \\
\hline \multicolumn{7}{|c|}{ Zone B } \\
\hline KDHE & AI & Nearshore & 18 & Watch & 16,000 & None \\
\hline KDHE & $\mathrm{AB}$ & Nearshore & 9 & Watch & 16,000 & None \\
\hline USACE & B3 & Open water & 11 & Watch & 300,000 & Warning \\
\hline USGS & B3 & Open water & 23 & Warning & -- & -- \\
\hline \multicolumn{7}{|c|}{ Zone A } \\
\hline KDHE & AA & Nearshore & $<0.50$ & None & 16,000 & None \\
\hline KDHE & $\mathrm{AH}$ & Nearshore & $<0.50$ & None & 4,700 & None \\
\hline USACE & A3 & Open water & 1.1 & None & 13,000 & None \\
\hline USGS & $\mathrm{S} 20$ & Open water & 1.7 & None & -- & -- \\
\hline USGS & $\mathrm{S} 21$ & Open water & 3.0 & None & -- & -- \\
\hline USGS & $\mathrm{S} 23$ & Open water & 0.21 & None & -- & -- \\
\hline USGS & A3 & Open water & 0.54 & None & -- & -- \\
\hline
\end{tabular}

${ }^{1}$ Based on Kansas Department of Health and Environment criteria for issuing public health advisories (Kansas Department of Health and Environment, 2015).

\section{Spatial Survey Results}

On August 31, 2015, regression-estimated chlorophyll concentrations at $0.5-\mathrm{m}$ depth in Milford Lake ranged from less than 0.02 to $990 \mu \mathrm{g} / \mathrm{L}$, with a median estimated concentration of $35 \mu \mathrm{g} / \mathrm{L}(n=720)$ (table 5). At $1.5-\mathrm{m}$ depth, estimated concentrations ranged from less than 0.02 to $380 \mu \mathrm{g} / \mathrm{L}$, with a median estimated concentration of $31 \mu \mathrm{g} / \mathrm{L}(n=720)$ (table 5). Overall, estimated chlorophyll concentrations were not significantly different between the two depths ( $U$-statistic, 245005; $p$-value, 0.072); however, estimated chlorophyll concentrations were significantly different between the two depths depending on zone. In Zone $\mathrm{C}$, estimated chlorophyll concentrations were significantly higher at $0.5 \mathrm{~m}$ (median: $120 \mu \mathrm{g} / \mathrm{L}$ ) than at $1.5 \mathrm{~m}$ (median: $77 \mu \mathrm{g} / \mathrm{L})(U$-statistic, 35774; $p$-value, less than 0.001) (table 5). The opposite pattern was observed in Zone A, where estimated chlorophyll concentrations were significantly higher at $1.5 \mathrm{~m}$ (median: $18 \mu \mathrm{g} / \mathrm{L}$ ) than at $0.5 \mathrm{~m}$ $(5.8 \mu \mathrm{g} / \mathrm{L})(U$-statistic, $11168 ; p$-value, less than 0.001) (table 5). Estimated chlorophyll concentrations were similar at 0.5 and $1.5 \mathrm{~m}$ (medians, 29 and $31 \mu \mathrm{g} / \mathrm{L}$, respectively) in Zone B (U-statistic, 9422; $p$-value, 0.341) (table 5).

As observed in July, estimated chlorophyll concentrations were indicative of higher algal biomass uplake, with decreases in the downlake direction (fig. 10). Median estimated chlorophyll concentrations at 0.5 and $1.5 \mathrm{~m}$ in Zone $\mathrm{C}$ were about 20 times and 4 times higher, respectively, than in Zone A, and about 4 times and 2 times higher, respectively, than in Zone B (figs. $11 A, 11 C$; table 5). Variability in estimated chlorophyll concentrations decreased in the downlake direction. Estimated 


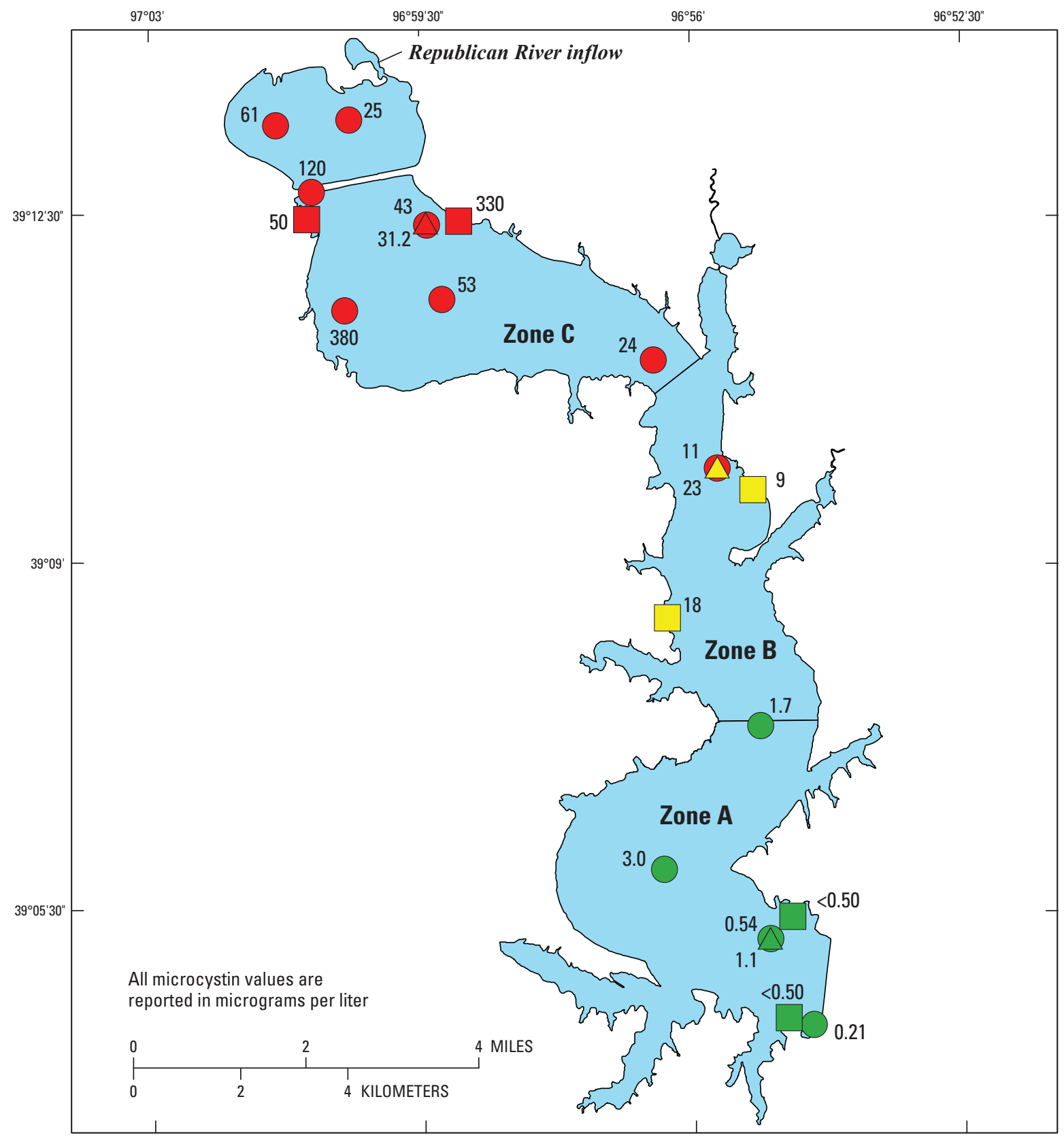

EXPLANATION

U.S. Geological Survey sample site

No advisory, 0 to $<4$ micrograms per liter

Warning, >20 micrograms per liter
Kansas Department of Health and Environment sample site

No advisory, 0 to $<4$ micrograms per liter

Watch, 4 to 20 micrograms per liter

Warning, >20 micrograms per liter

\section{U.S. Army Corps of Engineers sample site}
$\triangle$ No advisory, 0 to $<4$ micrograms per liter
$\triangle$ Watch, 4 to 20 micrograms per liter
$\triangle$ Warning, $>20$ micrograms per liter

Figure 9. Total microcystin concentration in discrete water-quality samples collected by the U.S. Geological Survey, the Kansas Department of Health and Environment, and the U.S. Army Corps of Engineers on August 31, 2015. 
Table 5. Summary statistics for regression estimated chlorophyll and total microcystin concentrations in Milford Lake on August 31, 2015.

[m, meter; $n$, number of samples; \pm , plus or minus; PI, 95-percent prediction interval; $<$, less than]

\begin{tabular}{|c|c|c|c|c|c|c|c|}
\hline \multirow{2}{*}{ Location } & \multirow{2}{*}{$n$} & \multicolumn{3}{|c|}{ Top sensor (0.5 m) } & \multicolumn{3}{|c|}{ Bottom sensor (1.5 m) } \\
\hline & & Minimum & Maximum & Median \pm PI & Minimum & Maximum & Median $\pm \mathbf{P}$ \\
\hline \multicolumn{8}{|c|}{ Chlorophyll, in micrograms per liter } \\
\hline Zone A & 260 & $<0.02( \pm 74)$ & $46( \pm 73)$ & $5.8( \pm 73)$ & $<0.02( \pm 74)$ & $67( \pm 72)$ & $18( \pm 73)$ \\
\hline Zone B & 142 & $8.8( \pm 73)$ & $390( \pm 81)$ & $29( \pm 73)$ & $7.4( \pm 73)$ & $160( \pm 73)$ & $31( \pm 73)$ \\
\hline Zone $\mathrm{C}$ & 318 & $27( \pm 73)$ & $990( \pm 130)$ & $120( \pm 72)$ & $18( \pm 73)$ & $380( \pm 80)$ & $77( \pm 72)$ \\
\hline Overall & 720 & $<0.02( \pm 74)$ & $990( \pm 130)$ & $35( \pm 73)$ & $<0.02( \pm 74)$ & $380(80)$ & $31( \pm 73)$ \\
\hline \multicolumn{8}{|c|}{ Total microcystin, in micrograms per liter } \\
\hline Zone A & 260 & $<0.02( \pm 27)$ & $10( \pm 27)$ & $<0.02( \pm 27)$ & $<0.02( \pm 27)$ & $17( \pm 27)$ & $0.81( \pm 27)$ \\
\hline Zone B & 460 & $<0.02( \pm 27)$ & $120( \pm 30)$ & $4.4( \pm 27)$ & $<0.02( \pm 27)$ & $50( \pm 27)$ & $4.9( \pm 27)$ \\
\hline Zone C & 318 & $3.7( \pm 27)$ & $310( \pm 50)$ & $33( \pm 27)$ & $0.72( \pm 27)$ & $120( \pm 30)$ & $20( \pm 27)$ \\
\hline Overall & 720 & $<0.02( \pm 27)$ & $310( \pm 50)$ & $6.3( \pm 27)$ & $<0.02( \pm 27)$ & $120( \pm 30)$ & $5.0( \pm 27)$ \\
\hline
\end{tabular}

chlorophyll concentrations had a range of about $970 \mu \mathrm{g} / \mathrm{L}$ in Zone $\mathrm{C}$, compared to $380 \mu \mathrm{g} / \mathrm{L}$ in Zone B and $67 \mu \mathrm{g} / \mathrm{L}$ in Zone A (figs. $11 A, 11 C$; table 5). These among-zone differences in estimated chlorophyll concentrations were statistically significant (all $Q$-statistics greater than 8 ; all $p$-values less than $0.001)$.

Regression-estimated microcystin concentrations at 0.5-m depth in Milford Lake on August 31, 2015, ranged from less than 0.02 to $310 \mu \mathrm{g} / \mathrm{L}$, with a median concentration of $6.3 \mu \mathrm{g} / \mathrm{L}(n=720)$ (table 5). At $1.5-\mathrm{m}$ depth, concentrations ranged from less than 0.02 to $120 \mu \mathrm{g} / \mathrm{L}$, with a median concentration of $5.0 \mu \mathrm{g} / \mathrm{L}(n=720)$ (table 5). Patterns with depth and among zones were similar to patterns in estimated chlorophyll concentrations (figs. 10-12). Although estimated microcystin concentrations were not significantly different between the two depths ( $U$-statistic, 248990; $p$-value, 0.193), concentrations were significantly different between the two depths in Zone $\mathrm{C}$ and $\mathrm{A}$. In Zone $\mathrm{C}$, estimated microcystin concentrations were significantly higher at $0.5 \mathrm{~m}$ (median: $33 \mu \mathrm{g} / \mathrm{L}$ ) than at $1.5 \mathrm{~m}$ (median, $20 \mu \mathrm{g} / \mathrm{L})(U$-statistic, 35774; $p$-value, less than 0.001 ) (table 5). The opposite pattern was observed in Zone A, where estimated microcystin concentrations were significantly higher at $1.5 \mathrm{~m}$ (median, $0.81 \mu \mathrm{g} / \mathrm{L}$ ) than at $0.5 \mathrm{~m}$ (median, less than $0.02 \mu \mathrm{g} / \mathrm{L})(U$-statistic, 14322; $p$-value, less than 0.001 ) (table 5). Estimated microcystin concentrations were similar at 0.5 and $1.5 \mathrm{~m}$ (medians, 4.4 and $4.9 \mu \mathrm{g} / \mathrm{L}$, respectively) in Zone B ( $U$-statistic, 9193; $p$-value, 0.197) (figs. $11 B$, $11 D$; table 5).

Estimated microcystin concentrations were higher uplake, with decreases in the downlake direction (fig. 12). The median estimated microcystin concentration was about 25 times higher at $1.5-\mathrm{m}$ depth in Zone $\mathrm{C}$ than in Zone A; at $0.5-\mathrm{m}$ depth the median estimated microcystin concentration in Zone A was less than the reporting threshold of $0.02 \mu \mathrm{g} / \mathrm{L}$.
The median estimated microcystin concentrations in Zone $\mathrm{C}$ were 8 times and 4 times higher at the 0.5 - and 1.5 -m depths, respectively, than in Zone B. Like chlorophyll, variability in estimated microcystin concentrations decreased in the downlake direction. Estimated microcystin concentrations in Zone $\mathrm{C}$ had a range of $310 \mu \mathrm{g} / \mathrm{L}$, compared to $120 \mu \mathrm{g} / \mathrm{L}$ in Zone B and about $10 \mu \mathrm{g} / \mathrm{L}$ in Zone A (figs. $11 B, 11 D$; table 5). These among-zone differences in estimated microcystin concentrations were statistically significant (all $Q$-statistics greater than 7; all $p$-values less than 0.001).

Despite differences in estimated microcystin concentrations at 0.5 and $1.5 \mathrm{~m}$, the percentage of estimated concentrations in each KDHE category for public-health advisories was similar between depths, and all data are described together. Based on estimated microcystin concentrations, about 25 percent of estimated values $(n=1440)$ were above the KDHE warning threshold of $20 \mu \mathrm{g} / \mathrm{L}$, about 25 percent were above the watch threshold of $4 \mu \mathrm{g} / \mathrm{L}$, and about 50 percent were below $4 \mu \mathrm{g} / \mathrm{L}$. As observed in July, patterns in publichealth advisory status among zones reflect the uplake to downlake pattern in estimated microcystin concentrations (fig. 12). In Zone $C(n=636)$, about 60 percent of estimated microcystin concentrations were above the warning threshold, and about 35 percent were above the watch threshold. In Zone B ( $n=142)$, about 10 percent of estimated microcystin concentrations were above the warning threshold, and 40 percent were above the watch threshold. By comparison, in Zone A ( $n=260)$, about 95 percent of the estimated microcystin concentrations were less than $4 \mu \mathrm{g} / \mathrm{L}$; about 5 percent of the estimated microcystin concentrations were above the watch threshold, and none were above the warning threshold (figs. 11B, 11D; table 5). 

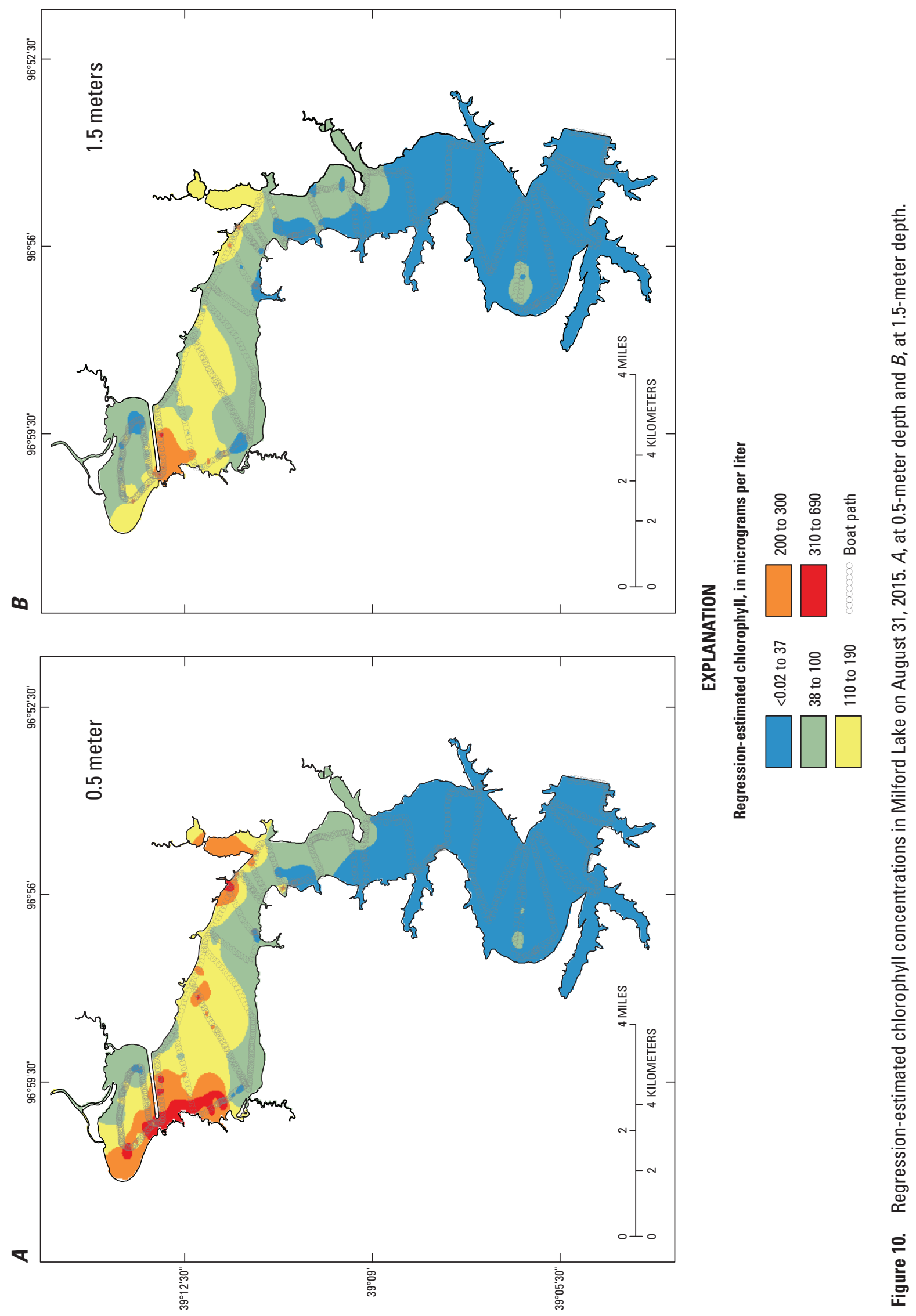


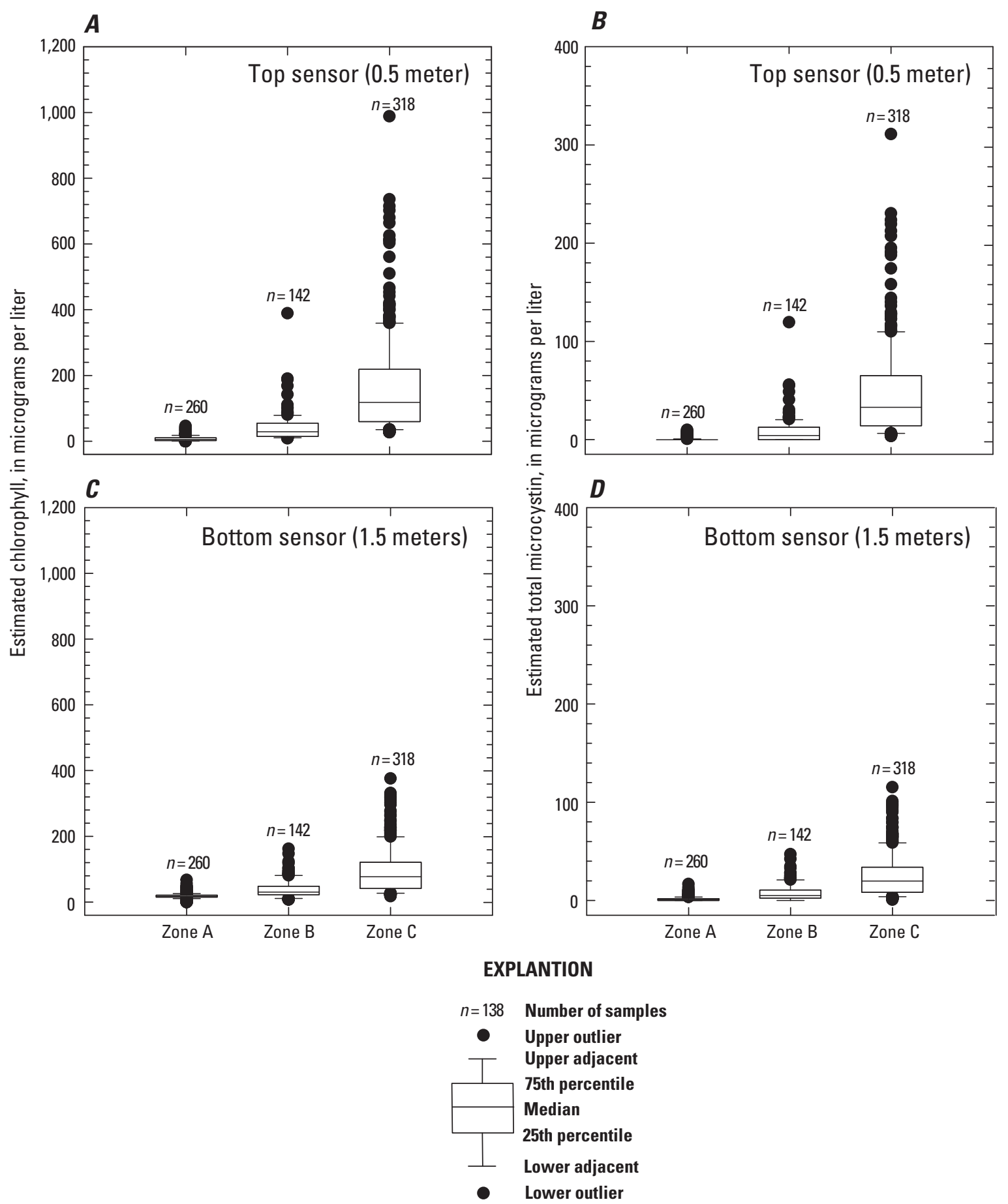

Figure 11. Box plots of regression-estimated chlorophyll and total microcystin concentrations in Milford Lake Zones $\mathrm{A}, \mathrm{B}$, and $\mathrm{C}$ on August 31,2015 . A, estimated chlorophyll at $0.5-\mathrm{m}$ depth; $B$, estimated total microcystin at $0.5-\mathrm{m}$ depth; $C$, estimated chlorophyll at $1.5-\mathrm{m}$ depth; and $D$, estimated total microcystin at $1.5-\mathrm{m}$ depth. 

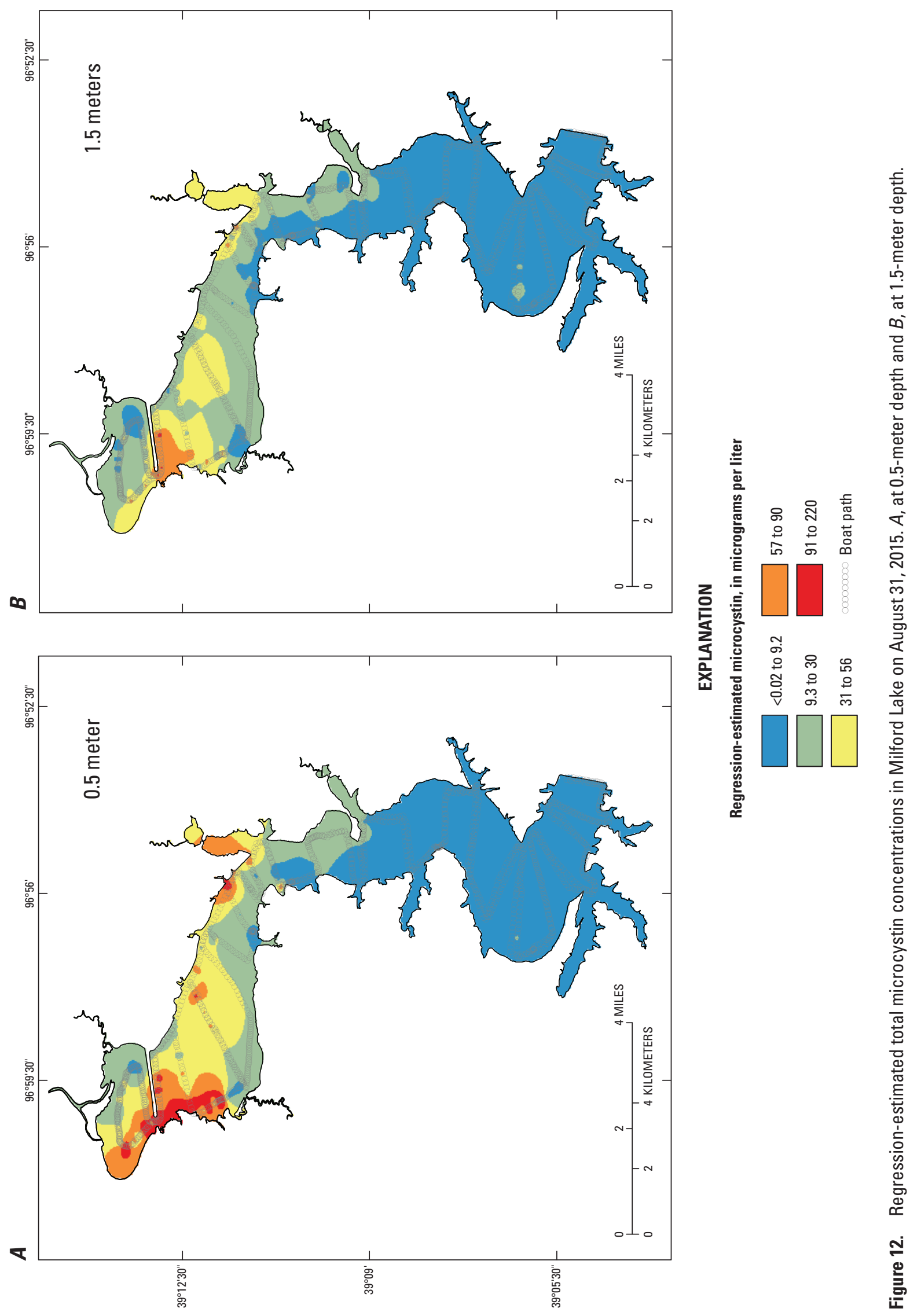


\section{Spatial Variability of Harmful Algal Blooms in Milford Lake}

The CyanoHAB in Milford Lake during July and August 2015 displayed the extreme spatial variability characteristic of cyanobacterial blooms (Graham and others, 2008). Cyanobacteria (measured directly by cell counts and indirectly by regression-estimated chlorophyll) and microcystin (measured directly by ELISA and estimated indirectly by regression) concentrations varied by orders of magnitude throughout the lake and within lake zones (figs. 5-12; tables 2-5). During July and August 2015, cyanobacteria and microcystin concentrations were highest in Zone $\mathrm{C}$ and decreased in the downlake direction. The observed up-to-down lake gradient in cyanobacteria and microcystin, with the highest concentrations in Zone $\mathrm{C}$, is typical in Milford Lake; however, substantial blooms occasionally are detected in Zone A (Graham and others, 2012; Kansas Department of Health and Environment, 2016b).

Because cyanobacteria have the ability to control their position in the water column, sample-collection techniques may substantially affect observed concentrations of microcystin (Graham and others, 2008; Graham and others, 2012). Nearshore surface grabs and open-water surface grabs were collected and analyzed for microcystin as part of this study. Overall, no consistent pattern was indicated in which sample location had the highest microcystin concentrations. In July, the maximum microcystin concentration observed in each zone was detected at a nearshore site. By comparison, in August, maximum microcystin concentrations in each zone were detected at an open-water site (figs. 5 and 9; tables 2 and 4). Higher nearshore concentrations are common and typically are caused by wind-driven accumulations of cyanobacteria (Graham and others, 2008). Differences in the location of the highest microcystin concentrations observed in July and August may have been caused by differences in meteorological conditions in the hours to days prior to sampling. Wind speed and direction in the days prior to sampling in July and August were generally similar; however, available meteorological data were from stations that were not proximate to Milford Lake (fig. 1) and local conditions may have been different.

The high-resolution spatial data collected at 0.5 and $1.5 \mathrm{~m}$ depths indicated vertical variability of cyanobacteria (as estimated by chlorophyll) and microcystin concentrations in Milford Lake. Vertical patterns differed between months and varied by lake zone. July regression-estimated concentrations of chlorophyll and microcystin were higher at $1.5 \mathrm{~m}$ than at $0.5 \mathrm{~m}$ in Zone A but were similar between the two depths in Zones C and B (figs. 6-8). Vertical differences in estimated chlorophyll and microcystin concentrations with depth were more pronounced in August. Zone A had the same pattern with depth as observed in July. Zone $\mathrm{C}$ had the opposite pattern of Zone A, with higher concentrations at $0.5 \mathrm{~m}$ than at $1.5 \mathrm{~m}$ (figs. 10-12). Vertical differences were not observed in Zone B. The observed pattern in July indicated that algal biomass was evenly distributed to a depth of at least $1.5 \mathrm{~m}$ in Zones $\mathrm{C}$ and $\mathrm{B}$ but was higher at depth than near the surface in Zone A. By comparison, the observed pattern in August suggested algal biomass was higher near the surface in Zone C, evenly distributed to a depth of at least $1.5 \mathrm{~m}$ in Zone B, and was higher at depth in Zone A. Temporal and among-zone differences in physical variables such as water column stability, light penetration in the water column, and wind speed and direction near the water surface may have affected algal distribution in the water column (Graham and others, 2016). Although observed patterns may indicate temporal and spatial variability of algal distribution in Milford Lake, differences also may be caused by variation in the relation between sensor-measured phycocyanin RFU, chlorophyll, and microcystin with depth. The phycocyanin sensor measures the fluorescence response of intracellular pigments, which may be affected by such factors as the thickness of algal cell walls, the physiological condition of the cells, and the heterogeneity of the algal communities being measured (Lawrenz and Richardson, 2011; Roesler and Barnard, 2013).

Based on the KDHE guidance for public-health advisories, July and August discrete water-quality samples were predominantly indicative of warning status in Zone $\mathrm{C}$, watch status in Zone B, and no advisories in Zone A. (tables 2 and 4). Regression-estimated microcystin concentrations, which provided more thorough coverage of Milford Lake $(n=683-$ $720)$ than discrete samples $(n=21-24)$, generally indicated the same overall pattern. Regardless of the sampling approach, the overall public-health advisory status of each zone in Milford Lake was similar according to the KDHE guidance levels.

\section{Summary}

Cyanobacterial harmful algal blooms (CyanoHABs) tend to be spatially variable vertically in the water column and horizontally across the lake surface because of in-lake and weather-driven processes and can vary by orders of magnitude in concentration across short distances (meters or less). Extreme spatial variability in cyanobacteria and associated compounds poses unique challenges to collecting representative samples for scientific study and public-health protection. The objective of this study was to assess the spatial variability of cyanobacteria and microcystin in Milford Lake, Kansas, using data collected on July 27 and August 31, 2015. Spatially-dense near-surface data were collected by the U.S. Geological Survey (USGS), nearshore data were collected by the Kansas Department of Health and Environment (KDHE), and open-water data were collected by the U.S. Army Corps of Engineers (USACE). Combined, these data were used to characterize the magnitude and variability of cyanobacterial abundance and microcystin concentrations in Milford Lake. A better understanding of the spatial variability of cyanobacteria and microcystin will inform sampling and management 
strategies for Milford Lake as well as other lakes with CyanoHAB issues throughout the Nation.

Milford Lake is a reservoir that was completed in 1967 by the USACE for the purposes of flood control, water supply, water quality, navigation, recreation, and wildlife. The KDHE divided Milford Lake into three zones for recreational monitoring because of the physical and limnological conditions of the lake and because CyanoHABs commonly are present in localized parts of the lake, which makes closing the entire lake unnecessary. Zone $\mathrm{C}$ is the uplake zone, Zone B is the midlake zone, and Zone A is the downlake zone. Milford Lake occasionally undergoes weak stratification near the dam and displays the longitudinal variability typical in reservoirs, with higher nutrient concentrations and turbidities uplake than downlake.

Data collection was coordinated between the USGS, KDHE, and USACE on July 27 and August 31, 2015. A combination of discrete water-quality samples (USGS, KDHE, and USACE) and fixed-site and spatially continuous waterquality data (USGS) were collected. Discrete water-quality samples collected by all three agencies were analyzed for total microcystin concentrations. Samples collected by the USGS also were analyzed for chlorophyll. Samples collected by the KDHE and some samples collected by USACE also were analyzed for phytoplankton abundance and community composition. The USGS discrete water-quality samples were collected from open-water locations as near-surface grabs. KDHE discrete water-quality samples were collected from six predetermined nearshore locations as near-surface grabs. The USACE discrete water-quality samples were collected from open-water locations as near-surface grabs.

Spatial data were collected using boat-mounted waterquality monitors during July 27, 2015, and August 31, 2015. Multiparameter water-quality monitors were mounted underneath the boat at about 0.5 - and $1.5-\mathrm{m}$ (meter) depths, and a nitrate sensor was mounted at about $1.0-\mathrm{m}$ depth. Laboratorymeasured chlorophyll (hereinafter referred to as chlorophyll) and total microcystin (hereinafter referred to microcystin) concentrations in Milford Lake at 0.5 and $1.5 \mathrm{~m}$ were estimated using linear regression models and sensor-measured phycocyanin fluorescence data collected using the mounted sensor array.

The CyanoHAB in Milford Lake during July and August 2015 displayed the extreme spatial variability characteristic of cyanobacterial blooms. Cyanobacteria (measured directly by cell counts and indirectly by regression-estimated chlorophyll) and microcystin (measured directly by enzyme-linked immunosorbent assay and indirectly by regression estimates) concentrations varied by orders of magnitude throughout the lake and within lake zones. During July and August 2015, cyanobacteria and microcystin concentrations were highest in uplake Zone $\mathrm{C}$ and decreased in the downlake direction.

Because cyanobacteria have the ability to control their position in the water column, sample-collection techniques may substantially affect observed concentrations of microcystin. Nearshore surface grabs and open-water surface grabs were collected and analyzed for microcystin as part of this study. Overall, no consistent pattern was indicated in which sample location had the highest microcystin concentrations. In July, the maximum microcystin concentration observed in each zone was detected at a nearshore site and in August, maximum microcystin concentrations in each zone were detected at an open-water site. Differences in the location of the highest microcystin concentrations observed in July and August may have been caused by differences in meteorological conditions in the hours to days prior to sampling.

The high-resolution spatial data collected at 0.5 - and $1.5-\mathrm{m}$ depths indicated vertical variability of cyanobacteria (as estimated by chlorophyll) and microcystin concentrations in Milford Lake. Vertical patterns differed between months and varied by lake zone. Temporal and among-zone differences in physical variables such as water column stability, light penetration in the water column, and wind speed and direction near the water surface may have influenced algal distribution in the water column. Although observed patterns may indicate temporal and spatial variability of algal distribution in Milford Lake, differences also may be caused by differences in the relation between sensor-measured phycocyanin relative fluorescence units, chlorophyll, and microcystin with depth.

The KDHE uses two guidance levels to issue recreational public-health advisories for cyanobacterial-related CyanoHABs in Kansas lakes. Public-health watches are issued when cyanobacterial abundance is between 80,000 and 250,000 cells per milliliter or microcystin concentrations are between 4 and 20 micrograms per liter. Public-health warnings are issued when cyanobacterial abundances or microcystin concentrations are greater than or equal to 250,000 cells per milliliter and 20 micrograms per liter, respectively. In July and August, discrete water-quality samples were predominantly indicative of warning status in Zone $\mathrm{C}$, watch status in Zone B, and no advisories in Zone A.

Regression-estimated microcystin concentrations, which provided more thorough coverage of Milford Lake $(n=683-$ $720)$ than discrete samples $(n=21-24)$, generally indicated the same overall pattern. Regardless of the sampling approach, the overall public-health advisory status of each zone in Milford Lake was similar according to the KDHE guidance levels.

\section{References Cited}

American Public Health Association, 1992, Standard methods for the examination of water and wastewater (17th ed): Washington, D.C., American Public Health Association, American Water Works Association, and Water Pollution Control Federation, 1,100 p.

Arar, E.J., and Collins, G.B., 1997, Method 445.0-In vitro determination of chlorophyll $a$ and pheophytin $a$ in marine and freshwater algae by fluorescence (rev. 1.2): U.S. Environmental Protection Agency, Office of Research and Development, $22 \mathrm{p}$. 
Carlson, R.E., 1977, A trophic state index for lakes: Limnology and Oceanography, v. 22, no. 2, p. 361-369.

EnviroLogix, 2015, Qualitube kit for microcystin: EnviroLogix, accessed October 21, 2016, at http://www.envirologix.com/wp-content/uploads/2015/05/ET022-Microcystin-101215.pdf.

Graham, J.L., Dubrovsky, N.M., and Eberts, S.M., 2016, Cyanobacterial harmful algal blooms and U.S. Geological Survey science capabilities: U.S. Geological Survey OpenFile Report 2016-1174, 12 p., accessed October 20, 2016, at http://dx.doi.org/10.3133/ofr20161174.

Graham, J. L., Loftin, K. A., Kamman, N., 2009, Monitoring recreational freshwaters: LakeLine, v. 29, p. 16-22.

Graham, J.L., Loftin, K.A., Meyer, M.T., and Ziegler, A.C., 2010, Cyanotoxin mixtures and taste-and-odor compounds in cyanobacterial blooms from the midwestern United States: Environmental Science and Technology, v. 44, p. 7361-7368.

Graham, J.L., Loftin, K.A., Ziegler, A.C., and Meyer, M.T., 2008, Cyanobacteria in lakes and Lakes-Toxin and tasteand-odor sampling guidelines (ver. 1.0): U.S. Geological Survey Techniques of Water-Resources Investigations, book 9, chap. A7, sec. 7.5, accessed September 1, 2016, at http:// pubs.water.usgs.gov/twri9A/.

Graham, J.L., Ziegler, A.C., Loving, B.L., and Loftin, K.A., 2012, Fate and transport of cyanobacteria and associated toxins and taste-and-odor compounds from upstream lake releases in the Kansas River, Kansas, September and October 2011: U.S. Geological Survey Scientific Investigations Report 2012-5129, 65 p. [Revised November 2012.]

Hambrook Berkman, J.A., and Canova, M.G., 2007, Algal biomass indicators (ver. 1.0): U.S. Geological Survey Techniques of Water-Resources Investigations, book 9, chap. A7, sec. 7.4, accessed October 21, 2016, at http://pubs.water. usgs.gov/twri9A/.

Helsel, D.R., and Hirsch, R.M., 2002, Statistical methods in water resources-Hydrologic analysis and interpretation: U.S. Geological Survey Techniques of Water-Resources Investigations, book 4, chap. A3, 510 p.

Kansas Department of Health and Environment, 2013, Kansas-Lower Republican Basin total maximum daily load: Kansas Department of Health and Environment, accessed October 20, 2016, at http:/www.kdheks.gov/tmdl/2013/ Milford_TMDL.pdf.

Kansas Department of Health and Environment, 2014, Division of Environment quality management plan part IIIKansas lake and wetland water quality monitoring program quality assurance management plan: Kansas Department of Health and Environment, accessed October 21, 2016, at http://www.kdheks.gov/environment/qmp/download/Lake_ and_Wetland_Part_III.pdf.
Kansas Department of Health and Environment, 2015, Policy_Guidelines for addressing harmful algal blooms in Kansas recreational waters: Kansas Department of Health and Environment Internal Directive 1101.1, accessed October 20, 2016, at http:/www.kdheks.gov/algae-illness/download/HAB_policy.pdf.

Kansas Department of Health and Environment, 2016a, Bluegreen algae (BGA) blooms: Kansas Department of Health and Environment, accessed October 20, 2016, at http:// www.kdheks.gov/algae-illness/index.htm.

Kansas Department of Health and Environment, 2016b, Historical HABs: Kansas Department of Health and Environment, accessed October 20, 2016, at http://www.kdheks. gov/algae-illness/historical_habs.htm.

Kansas Department of Health and Environment, 2016c, Kansas 303(d) list of impared waters, public hearing information and methodology: Kansas Department of Health and Environment, accessed October 20, 2016, at http://www. kdheks.gov/tmdl/methodology.htm.

Kansas Department of Health and Environment, 2016d, Kansas surface water monitoring, Milford Lake, from interactive map: Kansas Department of Health and Environment, accessed October 20, 2016, at http://kensas.kdhe.state.ks.us/ certop/SURWAT?id=LM019001.

Kansas Department of Health and Environment, 2016e, Zoned lakes in Kansas - Explanation for zone implementation: Kansas Department of Health and Environment, accessed October 20, 2016, at http:/www.kdheks.gov/algae-illness/ zoned_lakes.htm.

Kansas State University, 2016, Historical weather: Kansas State University, accessed October 20, 2016, at http:// mesonet.k-state.edu/weather/historical/.

Kansas Water Office, 2012, Milford Lake Reservoir information sheets: Kansas Water Office, accessed October 20, 2016, at http://www.kwo.org/Reservoirs/ReservoirInformationSheets/Rpt_Milford_2011.pdf.

King, L.R., Foster. G.M., and Graham, J.L., 2016a, Phytoplankton data for Milford Lake, Kansas, July 27 and August 31, 2015: U.S. Geological Survey data release, https://doi. org/10.5066/F7RX9971.

King, L.R., Foster. G.M., and Graham, J.L., 2016b, Milford Lake, Kansas spatial water-quality data, July 27 and August 31, 2015: U.S. Geological Survey data release, https://doi. org/10.5066/F7WQ01ZW.

King, L.R., Foster. G.M., and Graham, J.L., 2016c, Waterquality data from two sites on Milford Lake, Kansas July 26-27 and August 30-31, 2015: U.S. Geological Survey data release, https://doi.org/10.5066/F7V69GRH. 
Knowlton, M.F., 1984, Flow-through microcuvette for fluorometric determination of chlorophyll: Water Resources Bulletin, v. 20, p. 1198-1205.

Lane, S.L., Flanagan, Sarah, and Wilde, F.D., 2003, Selection of equipment for water sampling (ver. 2.0): U.S. Geological Survey Techniques of Water-Resources Investigations, book 9, chap. A2, accessed October 20, 2016, at http://pubs.water. usgs.gov/twri9A2/.

Lawrenz, E., and Richardson, T.L., 2011, How does the species used for calibration affect chlorophyll $a$ measurements by in situ fluorometry?: Estuaries and Coasts, v. 34, p. $873-883$.

Loftin, K.A., Meyer, M.T., Rubio, F., Kamp, L., Humphries, E., and Whereat, E., 2008, Comparison of two cell lysis procedures for recovery of microcystins in water samples from Silver Lake in Dover, Delaware, with microcystin producing cyanobacterial accumulations: U.S. Geological Survey Open-File Report 2008-1341, 9 p.

Loftin, K.A., Graham, J.L., Hilborn, E.D., Lehmann, S.C., Meyer, M.T., Dietze, J.E., and Griffith, C.B., 2016, Cyanotoxins in inland lakes of the United States-Occurrence and potential recreational health risks in the EPA National Lakes Assessment 2007: Harmful Algae, v. 56, p. 77-90.

Lund, J.W.G., Kipling, C., and LeCren, E.D., 1958, The inverted microscope method of estimated algal numbers and the statistical basis of estimates by counting: Hydrobiologia, v. 11, p. 143-170.

McNabb, C.D., 1960, Enumeration of freshwater phytoplankton concentrated on the membrane filter: Limnology and Oceanography, v. 5, p. 57-61.

O'Neil, J.M., Davis, T.W., Buford, M.A., and Gobler, C.J., 2012, The rise of harmful cyanobacterial blooms - The potential roles of eutrophication and climate change: Harmful Algae, v. 14, p. 313-334.

Pellerin, B.A., Bergamaschi, B.A., Downing, B.D., Franco, J., Garret, J.D., and Olsen, L.D., 2013, Optical techniques for the determination of nitrate in environmental watersGuidelines for instrument selection, operation, deployment, maintenance, quality assurance, and data reporting: U.S. Geological Survey Techniques and Methods, book 1, chap. D5, 37 p.

Roesler, C.S. and Barnard, A.H., 2013, Optical proxy for phytoplankton biomass in the absence of photophysiology-Rethinking the absorption line height: Methods in Oceanography, v. 7, p. 79-94.

Sartory, D.P., and Grobbelar, J.U., 1984, Extraction of chlorophyll $a$ from freshwater phytoplankton for spectrophotometric analysis: Hydrobiologia, v. 114, no. 3, p. 177-187.
Sauer, V.B., and Turnipseed, D.P., 2010, Stage measurement at gaging stations: U.S. Geological Survey Techniques and Methods, book 3, chap. A7, 45 p. [Also available at http:// pubs.usgs.gov/tm/tm3-a7/.]

Sokal, R.R., and Rohlf, F.J., 1995, Biometry-The principles and practice of statistics in biological research ( $3 \mathrm{~d}$ ed.): New York, W.H. Freeman and Company, 887 p.

Thornton, K.W., Kimmel, B.L., and Payne, F.E., eds., 1990, Reservoir limnology: Ecological perspectives: Somerset, New Jersey, John Wiley \& Sons, Inc., 246 p.

Trevino-Garrison, I., DeMent, J., Ahmed, F.S., Haines-Lieber, P., Langer, T., Menager, H., Neff, J., van der Merwe, D., Carney, E., 2015, Human illnesses and animal deaths associated with freshwater harmful algal blooms-Kansas: Toxins, v, 7, no. 2, p. 353-366.

Turnipseed, D.P., and Sauer, V.B., 2010, Discharge measurements at gaging stations: U.S. Geological Survey Techniques and Methods, book 3, chap. A8, 87 p. [Also available at http://pubs.usgs.gov/tm/tm3-a8/.]

U.S. Army Corps of Engineers, 2003, Water quality standard operating procedure no. 21101 - collection of surface water samples: Water Quality Unit, Water Control and Water Quality Section, Hydrologic Engineering Branch, Engineering Division, Omaha District, U.S. Army Corps of Engineers.

U.S. Army Corps of Engineers, Kansas City District, 2016a, Milford Lake water quality summary 2006-2015: U.S. Army Corps of Engineers, Kansas City District, accessed October 20, 2016, at http://www.nwk.usace.army.mil/ Portals/29/docs/lakesites/waterquality/2014\%20Maps\%20 and $\% 20$ Posts/2015/MI\%20Water\%20QualityPoster15. pdf?ver=2016-05-25-135638-570.

U.S. Army Corps of Engineers, Kansas City District, 2016b, Water quality data, Milford Lake, Water quality chemistry data: U.S. Army Corps of Engineers, Kansas City District, accessed October 20, 2016, at http://www.nwk.usace.army. mil/Locations/Water-Quality/.

U.S. Geological Survey, variously dated, National field manual for the collection of water-quality data: U.S. Geological Survey Techniques of Water-Resources Investigations, book 9, chaps. A1-A10, accessed October 20, 2016, at http:// pubs.water.usgs.gov/twri9A.

Yellow Springs Instruments (YSI), 2016, EXO user manualAdvanced water quality monitoring platform: Yellow Springs Instruments, revision F, 156 p., accessed October 21, 2016, at https://www.ysi.com/File\%20Library/Documents/Manuals/EXO-User-Manual-Web.pdf.

Zar, J.H., 1999, Biostatistical analysis (4th ed.): Upper Saddle River, N.J., Prentice Hall Inc., 663 p. 
Appendixes 1 and 2 


\section{Appendix 1. Model Archival Summary for Chlorophyll Concentration at Milford Lake, July 27, 2015, and August 31, 2015}

This model archival summary summarizes the chlorophyll concentration (Lab-Chl) model developed to estimate chlorophyll concentrations at Milford Lake on July 27, 2015, and August 31, 2015. This model is specific to the spatial data collected during this study and cannot be applied to other data collected from Milford Lake, or data collected from other lakes.

\section{Site and Model Information}

Site name: Milford Lake, Kansas

Equipment: A Yellow Springs Instruments Inc. (YSI) EXO2 water-quality monitor equipped with sensors for water temperature, specific conductance, dissolved oxygen, $\mathrm{pH}$, turbidity, chlorophyll, and phycocyanin was mounted under a boat at 0.5 meter depth for spatial surveys conducted on Milford Lake on July 27, 2015, and August 31, 2015. Boat speed was approximately 14 kilometers per hour, which provided the best balance of data quality and the ability to conduct a representative survey of the lake in a timely manner. Readings from the water-quality monitor were recorded every 30 seconds.

Date model was created: June 27, 2016

Model calibration data period: July 27, 2015, and August 31, 2015

Model application date: July 27, 2015, and August 31, 2015

\section{Model-Calibration Dataset}

All data were collected using U.S. Geological Survey protocols (U.S. Geological Survey, variously dated; http://water.usgs.gov/owq/FieldManual/) and are stored in the National Water Information System database at $h t t p: / / d x$.doi.org/10.5066/F7P55KJN. The explanatory variable selected as input to the linear regression was phycocyanin, in relative fluorescence units (RFU). Because discrete samples were collected just below the water surface and a sensor was located at 0.5 meter, this approach assumes that the relation between sensor-measured phycocyanin RFU and chlorophyll did not change with depth. The linear regression model was developed using the open-source software package R.

The regression model is based on 22 concurrent measurements of sensor-measured phycocyanin and laboratory-measured chlorophyll (uncorrected for degradation products) collected on July 23, 2015, and August 31, 2015. No samples were below sensor- or laboratory-detection limits. Summary statistics and the complete model-calibration dataset are provided in this appendix. A sample, collected at 10:30 a.m. on August 31, 2015, was considered an outlier and excluded from the regression model because the sample was from a surface accumulation of cyanobacteria and the chlorophyll concentration was an order of magnitude higher than any other measured concentrations.

\section{Chlorophyll Sampling Details}

All chlorophyll samples for laboratory analysis were collected as near-surface grab samples from openwater locations. Sample locations were not predetermined and were selected to represent the range of 
cyanobacterial conditions in the lake based on visual cues and continuous water-quality monitor data. Samples were analyzed for chlorophyll concentration at the U.S. Geological Survey Kansas Water Science Center.

\section{Model Development}

Ordinary least squares regression analysis was done using R with sensor-measured phycocyanin RFU as the explanatory variable for laboratory-measured chlorophyll concentrations. The distribution of residuals was examined for normality, and plots of residuals (the difference between the measured and computed values) as compared to computed chlorophyll were examined for homoscedasticity (meaning that their departures from zero did not change substantially over the range of computed values). Values for all regression statistics and metrics are included in this appendix along with all relevant sample data and more indepth statistical information.

\section{Model Summary}

The following is a summary of final regression analysis for sensor-measured phycocyanin relative fluorescence units (RFU) and laboratory-measured chlorophyll at Milford Lake, July 27, 2015, and August $31,2015$.

Chlorophyll concentration model:

$$
\text { Lab_Chl }=27.5 \times \text { Sensor_PCY }-5.48
$$

where

Lab_Chl = laboratory-measured chlorophyll in micrograms per liter $(\mu \mathrm{g} / \mathrm{L})$; and,

Sensor_PCY = sensor-measured phycocyanin in relative fluorescence units (RFU). 
R Output for the relation between sensor-measured phycocyanin relative fluorescence units (RFU) and laboratory-measured chlorophyll at Milford Lake, July 27, 2015, and August 31, 2015

\section{Model Statistics, Data, and Plots}

Definitions for terms used in this output can be found at the end of this document.

\section{Model}

Lab_Chl $=+27.5 *$ Sensor_Pcy -5.48

\section{Variable Summary Statistics}

$\begin{array}{lrr} & \text { Lab_Chl } & \text { Sensor_Pcy } \\ \text { Minimum } & 2.93 & 0.17 \\ \text { 1st Quartile } & 23.20 & 0.68 \\ \text { Median } & 60.90 & 2.26 \\ \text { Mean } & 105.00 & 4.00 \\ \text { 3rd Quartile } & 115.00 & 4.91 \\ \text { Maximum } & 461.00 & 16.60\end{array}$

\section{Box Plots}

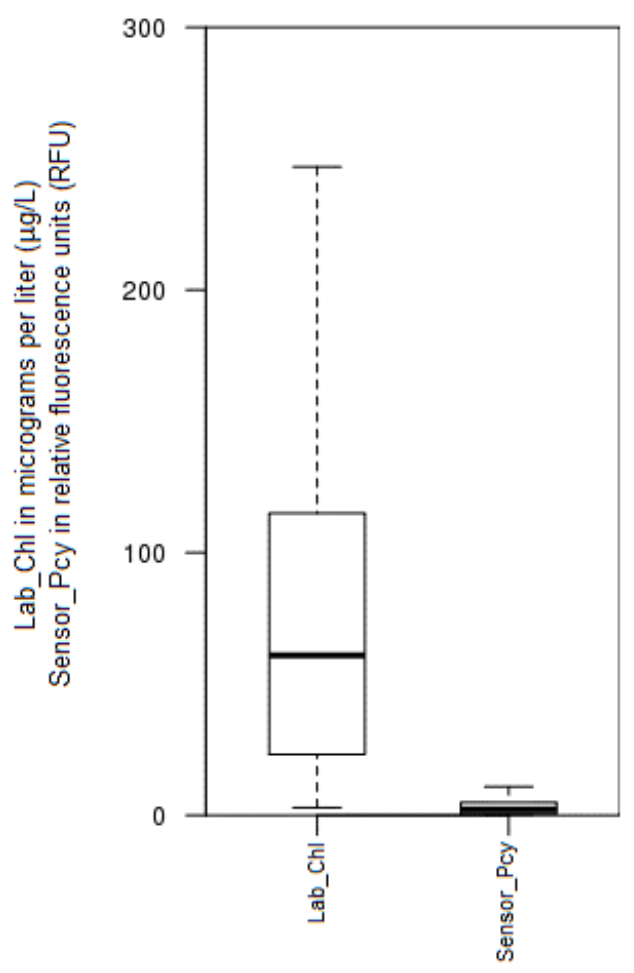

\section{EXPLANATION}

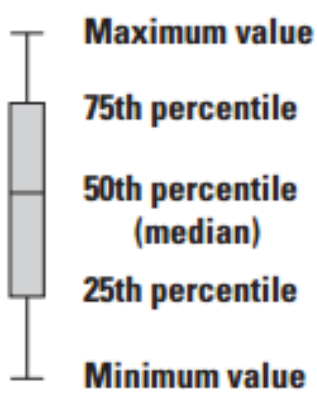




\section{Exploratory Plots}
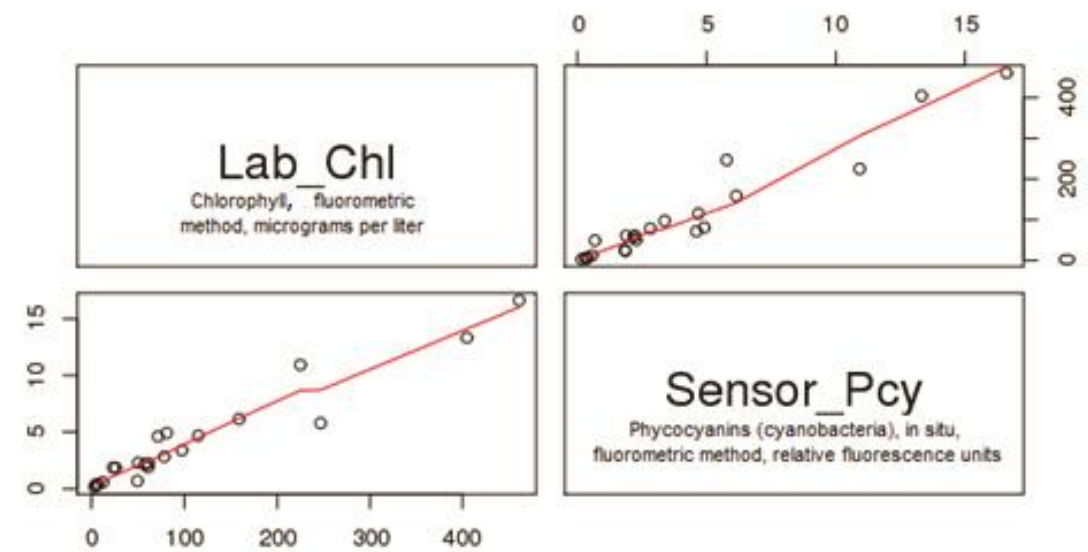

Red line shows the locally weighted scatterplot smoothing (LOWESS).

\section{Basic Model Statistics}

For a detailed explanation of the terms used below, refer to Helsel and Hirsch (2002).

Number of Observations

22

Standard error (RMSE)

34

Upper Model standard percentage error (MSPE)

32.6

Lower Model standard percentage error (MSPE)

32.6

Coefficient of determination $\left(R^{2}\right)$

0.93

Adjusted Coefficient of Determination (Adj. $R^{2}$ ) 0.926

\section{Explanatory Variables}

$\begin{array}{lrrrr} & \text { Coefficients } & \text { Standard Error } t & \text { value } & \text { Probability }(>|t|) \\ \text { (Intercept) } & -5.48 & 9.91 & -0.553 & 5.86 \mathrm{e}-01 \\ \text { Sensor_Pcy } & 27.50 & 1.69 & 16.300 & 5.21 \mathrm{e}-13\end{array}$

\section{Correlation Matrix}

$\begin{array}{lrc} & \text { Intercept } & \text { Sensor_Pcy } \\ \text { Intercept } & 1.000 & -0.681 \\ \text { Sensor_Pcy } & -0.681 & 1.000\end{array}$

\section{Outlier Test Criteria}

Leverage Cook's D DFFITS
0.136
0.106
0.426 


\section{Flagged Observations}

$\begin{array}{lrrrrrrrr} & \text { Lab_Chl } & \text { Estimate } & \text { Residual } & \text { Standard Residual } & \text { Studentized Residual } & \text { Leverage Cook's D DFFITS } \\ 1 & 247 & 154 & 93.30 & 2.820 & 3.540 & 0.0533 & 0.2230 & 0.839 \\ 3 & 461 & 452 & 9.29 & 0.364 & 0.356 & 0.4380 & 0.0516 & 0.314 \\ 12 & 225 & 295 & -70.00 & -2.250 & -2.540 & 0.1640 & 0.4950 & -1.120 \\ 14 & 405 & 361 & 43.50 & 1.490 & 1.530 & 0.2600 & 0.3870 & 0.909\end{array}$

\section{Statistical Plots}
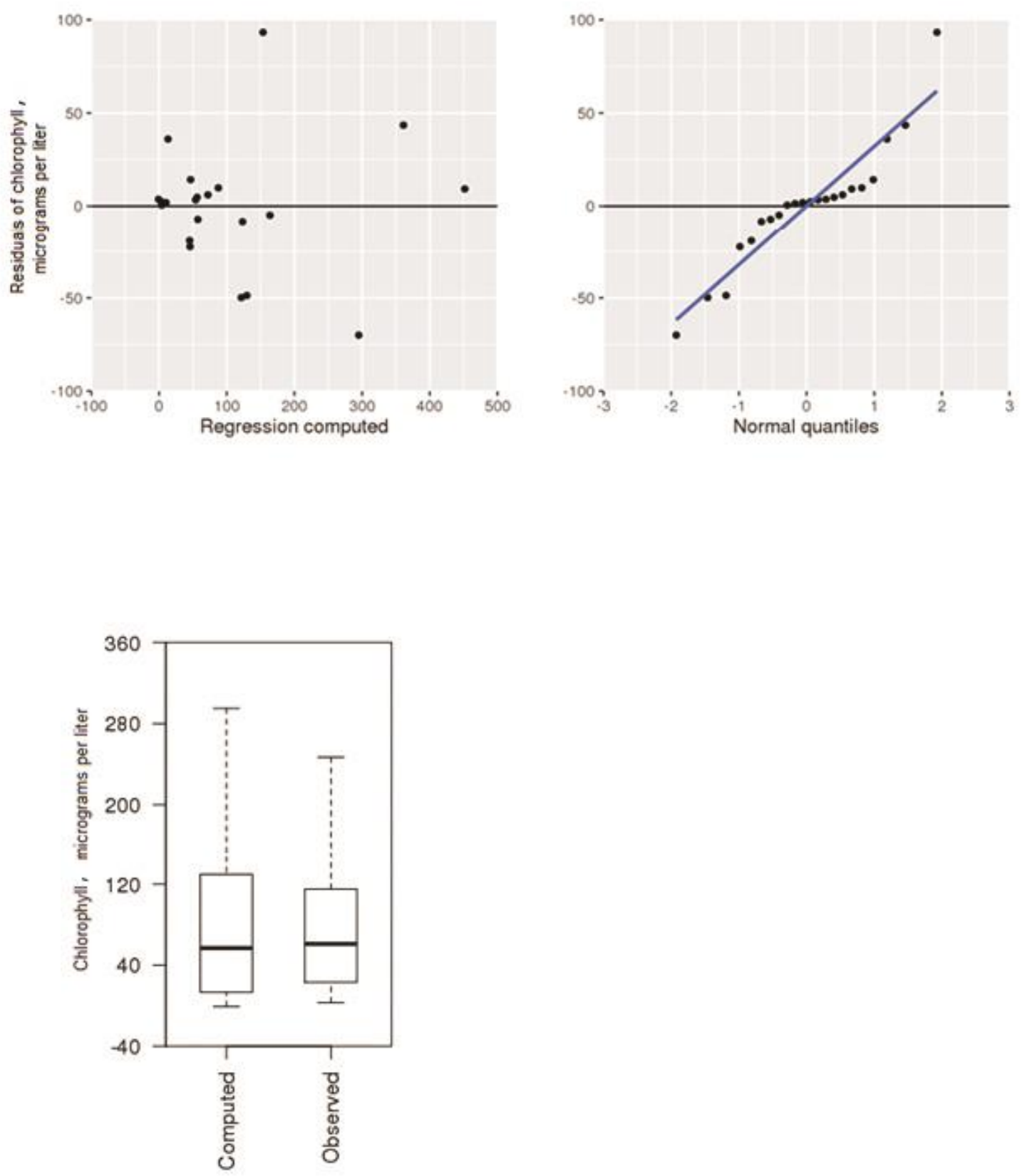


\section{Cross Validation}

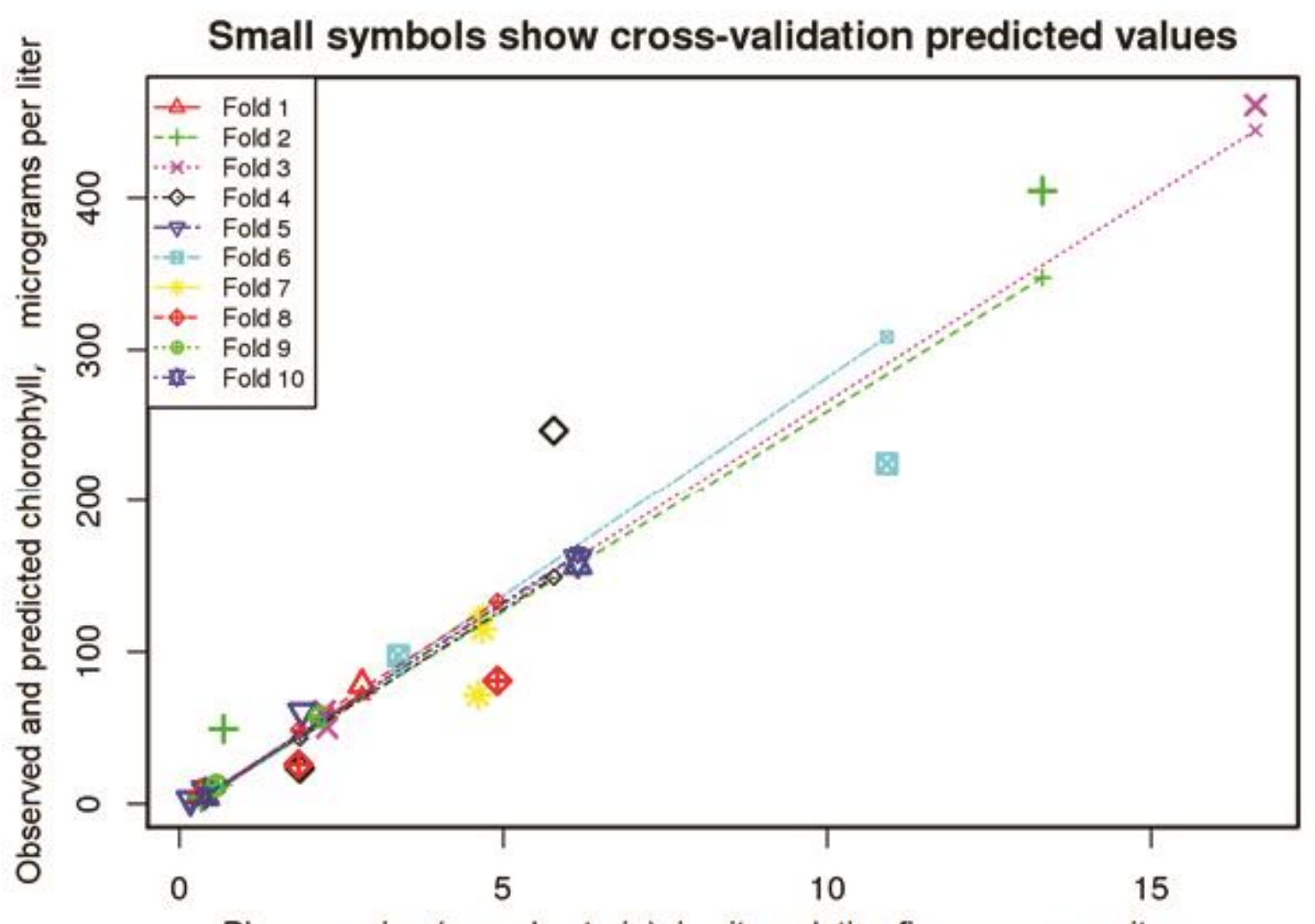

Phycocyanins (cyanobacteria), in situ, relative fluorescence units

Minimum model standard error (MSE) of folds: $\quad 9.84$

Mean MSE of folds: 1340.00

Median MSE of folds: 796.00

Maximum MSE of folds: 4980.00

(Mean MSE of folds) / (Model MSE): 1.16 


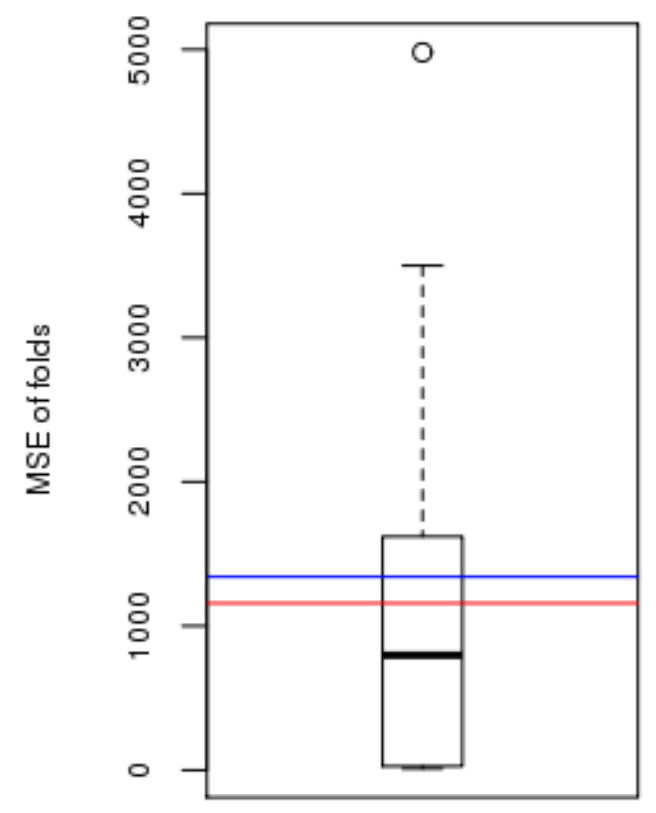

Red line - Model MSE

Blue line - Mean MSE of folds

Model-Calibration Data Set

date time Lab_Chl Sensor_Pcy Computed Residual Normal Censored

\section{0}

$17 / 27 / 20158: 30$

$27 / 27 / 20158: 40$

3 7/27/2015 9:10

4 7/27/2015 9:40

5 7/27/2015 11:00

6 7/27/2015 11:30

7 7/27/2015 11:50

$87 / 27 / 2015$ 12:50

$97 / 27 / 2015$ 13:20

$107 / 27 / 2015$ 14:30

$117 / 27 / 2015$ 15:40

$128 / 31 / 20159: 10$

$138 / 31 / 20159: 20$
247

71.6

461

80.9

49.3

61

60.8

23.2

25.9

2.93

50.2

225

97.4
Lab_Chl

5.78

4.61

16.6

4.91

0.68

2.24

1.89

1.86

1.84

0.17

2.28

10.9

3.38
154

121

452

130

13.2

56.2

46.5

45.7

45.2

$-0.803$

57.3

295

87.6
Quantiles Values

$93.3 \quad 1.93 \quad-$

$-49.8-1.46$

$9.29 \quad 0.667$

$-48.7-1.19$

1.19

0.406

0.986

$-0.986$

$-0.816$

0.286

$-0.532$

$-1.93$

0.816 


\begin{tabular}{|c|c|c|c|c|c|c|c|}
\hline 14 & $8 / 31 / 20159: 40$ & 405 & 13.3 & 361 & 43.5 & 1.46 & -- \\
\hline 15 & $8 / 31 / 2015 \quad 10: 00$ & 115 & 4.68 & 123 & -8.32 & -0.667 & -- \\
\hline 16 & $8 / 31 / 201510: 50$ & 159 & 6.15 & 164 & -4.88 & -0.406 & -- \\
\hline 17 & $8 / 31 / 2015 \quad 11: 30$ & 78.2 & 2.82 & 72.1 & 6.11 & 0.532 & -- \\
\hline 18 & $8 / 31 / 2015 \quad 12: 10$ & 57.4 & 2.16 & 54 & 3.4 & 0.17 & -- \\
\hline 19 & $8 / 31 / 2015 \quad 13: 10$ & 6.93 & 0.4 & 5.53 & 1.4 & -0.17 & -- \\
\hline 20 & $8 / 31 / 2015 \quad 14: 00$ & 12.2 & 0.57 & 10.2 & 1.97 & -0.0565 & -- \\
\hline 21 & $8 / 31 / 2015 \quad 15: 10$ & 5.76 & 0.32 & 3.33 & 2.43 & 0.0565 & -- \\
\hline 22 & $8 / 31 / 2015 \quad 15: 30$ & 4.47 & 0.34 & 3.88 & 0.594 & -0.286 & - - \\
\hline
\end{tabular}

Definitions

Cook's D: Cook's distance (Helsel and Hirsch, 2002). DFFITS: Difference in fits statistic (Helsel and Hirsch, 2002).

Leverage: An outlier's measure in the $x$ direction (Helsel and Hirsch, 2002). Lab_Chl: Chlorophyll, fluorometric method, uncorrected, micrograms per liter (32217). LOWESS: Locally weighted scatterplot smoothing (Cleveland, 1979; Helsel and Hirsch, 2002).

MSE: Model standard error (Helsel and Hirsch, 2002).

MSPE: Model standard percentage error (Helsel and Hirsch, 2002).

Probability $(>|t|)$ : The probability that the independent variable has no effect on the dependent variable (Helsel and Hirsch, 2002).

RMSE: Root mean square error (Helsel and Hirsch, 2002).

Sensor_Pcy: in Phycocyanins (cyanobacteria), water, in situ, fluorometric method, excitation at $590+-15 \mathrm{~nm}$, emission at $685+-20 \mathrm{~nm}$, relative fluorescence units (RFU) (32321).

t value: Student's t value; the coefficient divided by its associated standard error (Helsel and Hirsch, 2002).

\section{References Cited}

Cleveland, W.S., 1979, Robust Locally Weighted Regression and Smoothing Scatterplots: J. Am.

Stat. Assoc. 74, 829-836.

Helsel, D.R., and Hirsch, R.M., 2002, Statistical methods in water resources-Hydrologic analysis and interpretation: U.S. Geological Survey Techniques of Water-Resources Investigations, book 4, chap. A3, $510 \mathrm{p}$.

U.S. Geological Survey, variously dated, National field manual for the collection of water-quality data: U.S. Geological Survey Techniques of Water-Resources Investigations, book 9, chaps. A1-A9. 


\section{Appendix 2. Model Archival Summary for Total Microcystin Concentration Milford Lake, July 27, 2015, and August 31, 2015}

This model archival summary summarizes the total microcystin concentration (Lab_MC) model developed to estimate total microcystin concentrations at Milford Lake on July 27, 2015, and August 31, 2015. This model is specific to the spatial data collected during this study and cannot be applied to other data collected from Milford Lake, or data collected from other lakes.

\section{Site and Model Information}

Site name: Milford Lake, Kansas

Equipment: A Yellow Springs Instruments Inc. (YSI) EXO2 water-quality monitor equipped with sensors for water temperature, specific conductance, dissolved oxygen, $\mathrm{pH}$, turbidity, chlorophyll, and phycocyanin was mounted under a boat at 0.5 meter depth for spatial surveys conducted on Milford Lake on July 27, 2015, and August 31, 2015. Boat speed was approximately 14 kilometers per hour, which provided the best balance of data quality and the ability to conduct a representative survey of the lake in a timely manner. Readings from the water-quality monitor were recorded every 30 seconds.

Date model was created: June 27, 2016

Model calibration data period: July 27, 2015, and August 31, 2015

Model application date: July 27, 2015, and August 31, 2015

\section{Model-Calibration Dataset}

All data were collected using U.S. Geological Survey protocols (U.S. Geological Survey, variously dated; http://water.usgs.gov/owq/FieldManual/) and are stored in the National Water Information System database at $h t t p: / / d x$. doi.org/10.5066/F7P55KJN. The explanatory variable selected as input to the linear regression was phycocyanin, in relative fluorescence units (RFU). Because discrete samples were collected just below the water surface and a sensor was located at 0.5 meter, this approach assumes that the relation between sensor-measured phycocyanin RFU and total microcystin did not change with depth. The linear regression model was developed using the open-source software package R.

The regression model is based on 22 concurrent measurements of sensor-measured phycocyanin and laboratory-measured total microcystin collected on July 23, 2015, and August 31, 2015. No samples were below sensor- or laboratory-detection limits. Summary statistics and the complete model-calibration dataset are provided in this appendix. A sample, collected at 10:30 a.m. on August 31, 2015, was considered an outlier and excluded from the regression model because the sample was from a surface accumulation of cyanobacteria and the microcystin concentration was 2 times higher than any other measured concentrations.

\section{Total Microcystin Sampling Details}

All total microcystin samples for laboratory analysis were collected as near-surface grab samples from open-water locations. Sample locations were not predetermined and were selected to represent the 
range of cyanobacterial conditions in the lake based on visual cues and continuous water-quality monitor data. Samples were analyzed for total microcystin concentration at the U.S. Geological Survey Organic Geochemistry Research Laboratory.

\section{Model Development}

Ordinary least squares regression analysis was done using R with sensor-measured phycocyanin RFU as the explanatory variable for laboratory-measured total microcystin concentrations. The distribution of residuals was examined for normality, and plots of residuals (the difference between the measured and computed values) as compared to computed microcystin were examined for homoscedasticity (meaning that their departures from zero did not change substantially over the range of computed values). Values for all regression statistics and metrics are included in this appendix along with all relevant sample data and more indepth statistical information.

\section{Model Summary}

The following is a summary of final regression analysis for sensor-measured phycocyanin relative fluorescence units (RFU) and laboratory-measured total microcystin at Milford Lake, July 27, 2015, and August 31, 2015.

Total microcystin concentration model:

$L a b \_M C=8.79 \times$ Sensor_PCY -6.66

where

$L a b \_M C=$ laboratory-measured total microcystin in micrograms per liter $(\mu \mathrm{g} / \mathrm{L}) ;$ and,

Sensor_PCY = sensor-measured phycocyanin in relative fluorescence units (RFU). 
$R$ Output for the relation between sensor-measured phycocyanin relative fluorescence units (RFU) and laboratory-measured total microcystin at Milford Lake, July 27, 2015 and August 31, 2015

\section{Model Statistics, Data, and Plots}

Definitions for terms used in this output can be found at the end of this document.

\section{Model}

Lab_MC $=+8.79 *$ Sensor_Pcy -6.66

Variable Summary Statistics

$\begin{array}{lrr} & \text { Lab_MC } & \text { Sensor_Pcy } \\ \text { Minimum } & 0.21 & 0.17 \\ \text { 1st Quartile } & 3.00 & 0.68 \\ \text { Median } & 12.50 & 2.26 \\ \text { Mean } & 28.50 & 4.00 \\ \text { 3rd Quartile } & 38.00 & 4.91 \\ \text { Maximum } & 160.00 & 16.60\end{array}$

\section{Box Plots}

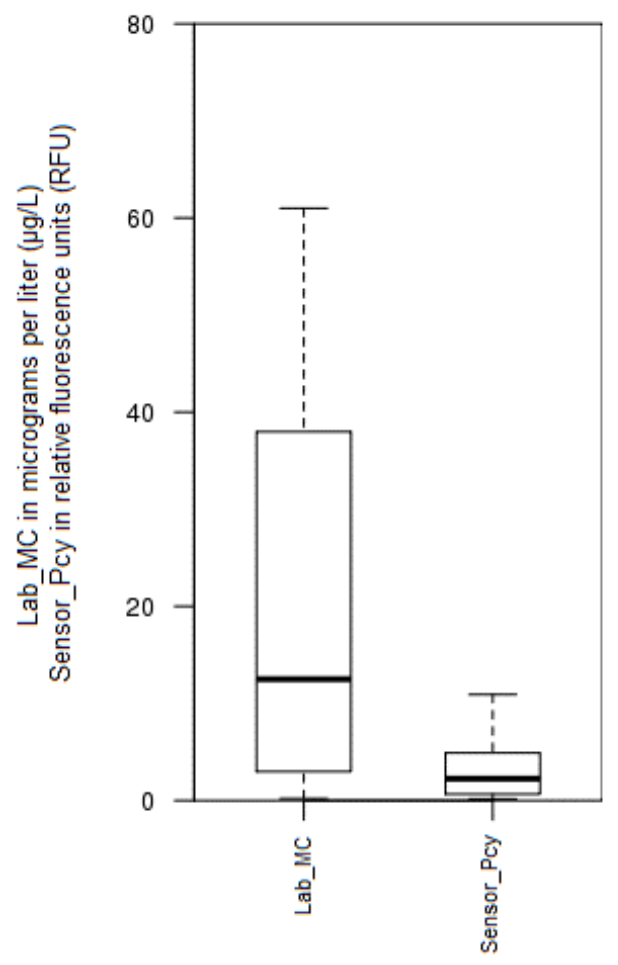

\section{EXPLANATION}

Maximum value

75th percentile

50th percentile (median)

25th percentile

Minimum value 


\section{Exploratory Plots}
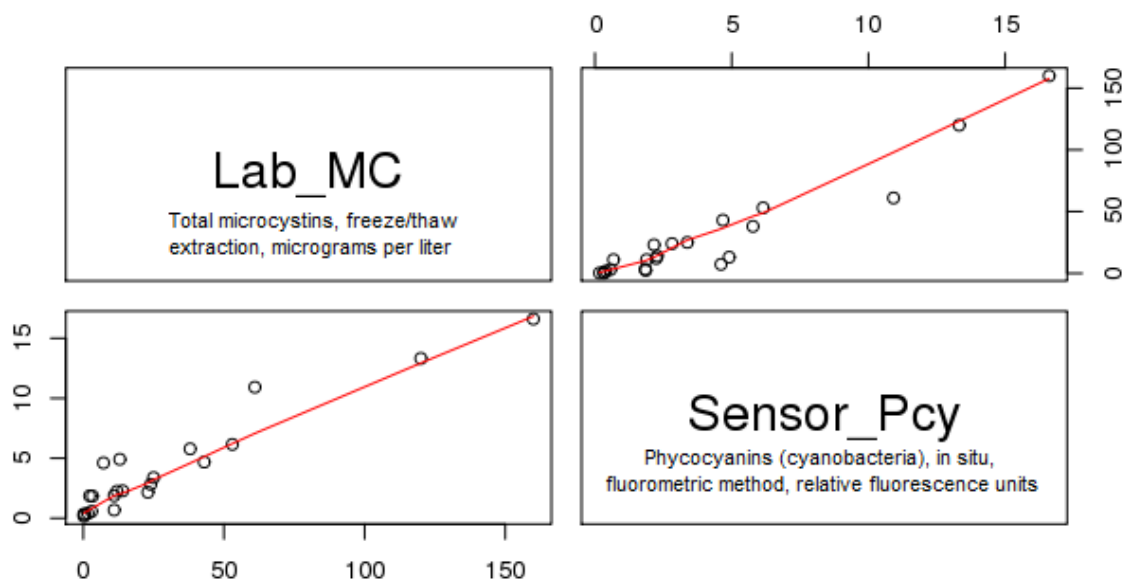

\section{Sensor_Pcy}

Phycocyanins (cyanobacteria), in situ, fluorometric method, relative fluorescence units

Red line shows the locally weighted scatterplot smoothing (LOWESS).

\section{Basic Model Statistics}

For a detailed explanation of the terms used below, refer to Helsel and Hirsch (2002).

Number of Observations

Standard error (RMSE)

12.7

Upper Model standard percentage error (MSPE) 44.5

Lower Model standard percentage error (MSPE) 44.5

Coefficient of determination $\left(R^{2}\right) \quad 0.907$

Adjusted Coefficient of Determination (Adj. $R^{2}$ ) 0.902

\section{Explanatory Variables}

$\begin{array}{lrrrr} & \text { Coefficients } & \text { Standard Error } t & \text { value } & \text { Probability }(>|t|) \\ \text { (Intercept) } & -6.66 & 3.70 & -1.8 & 8.68 \mathrm{e}-02 \\ \text { Sensor_Pcy } & 8.79 & 0.63 & 14.0 & 9.07 \mathrm{e}-12\end{array}$

\section{Correlation Matrix}

$\begin{array}{lrc} & \text { Intercept } & \text { Sensor_Pcy } \\ \text { Intercept } & 1.000 & -0.681 \\ \text { Sensor_Pcy } & -0.681 & 1.000\end{array}$

\section{Outlier Test Criteria}
Leverage Cook's D
DFFITS
0.136
0.106
0.426 


\section{Flagged Observations}

$\begin{array}{lrrrrrrrr} & \text { Lab_MC } & \text { Estimate } & \text { Residual Standard Residual } & \text { Studentized Residual } & \text { Leverage Cook's D DFFITS } \\ 2 & 7.2 & 33.9 & -26.70 & -2.150 & -2.390 & 0.0464 & 0.1130 & -0.528 \\ 3 & 160.0 & 139.0 & 20.70 & 2.170 & 2.420 & 0.4380 & 1.8400 & 2.140 \\ 4 & 13.0 & 36.5 & -23.50 & -1.900 & -2.040 & 0.0475 & 0.0899 & -0.456 \\ 12 & 61.0 & 89.3 & -28.30 & -2.440 & -2.840 & 0.1640 & 0.5830 & -1.260 \\ 14 & 120.0 & 110.0 & 9.58 & 0.877 & 0.872 & 0.2600 & 0.1350 & 0.517\end{array}$

\section{Statistical Plots}
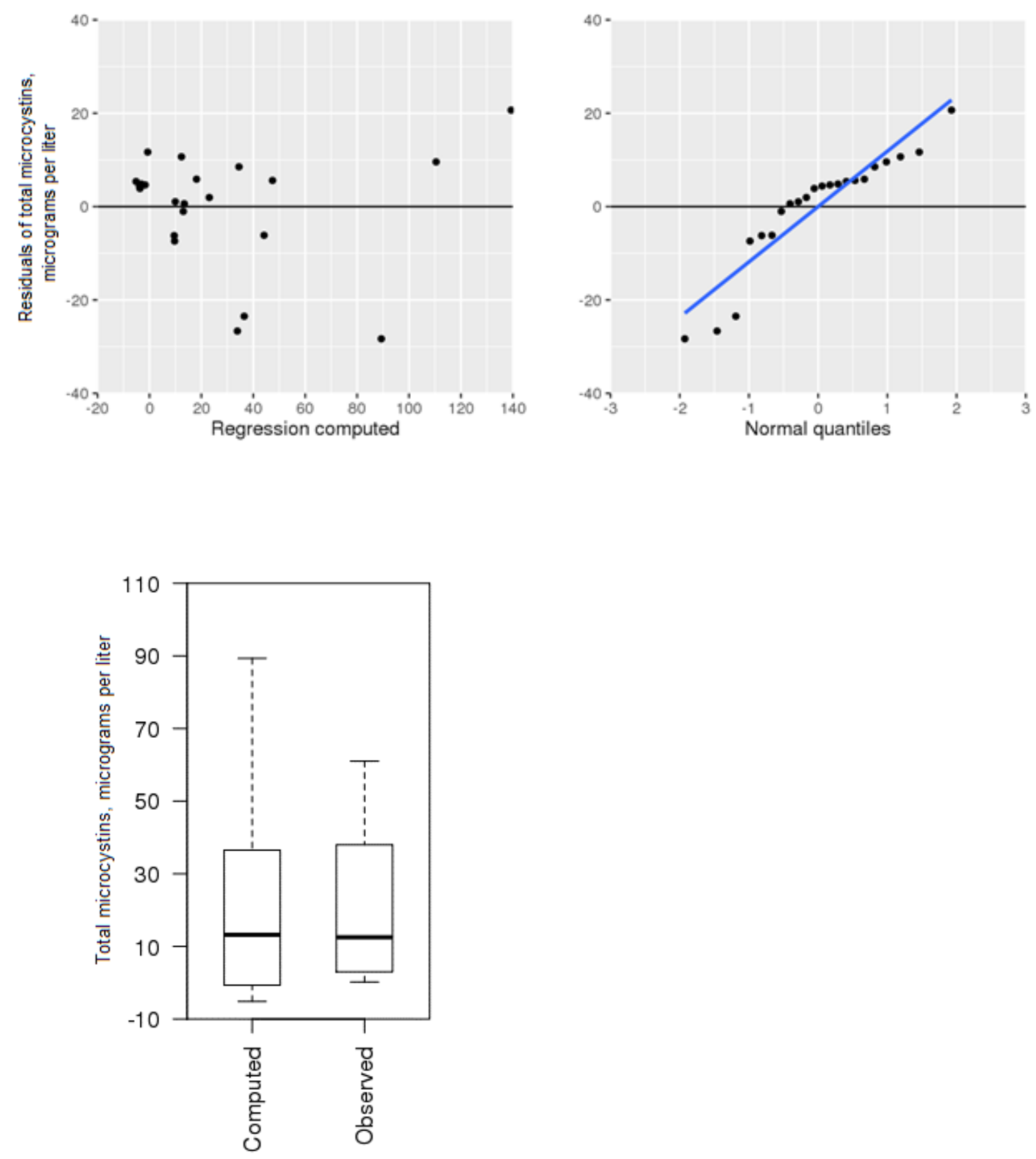


\section{Cross Validation}

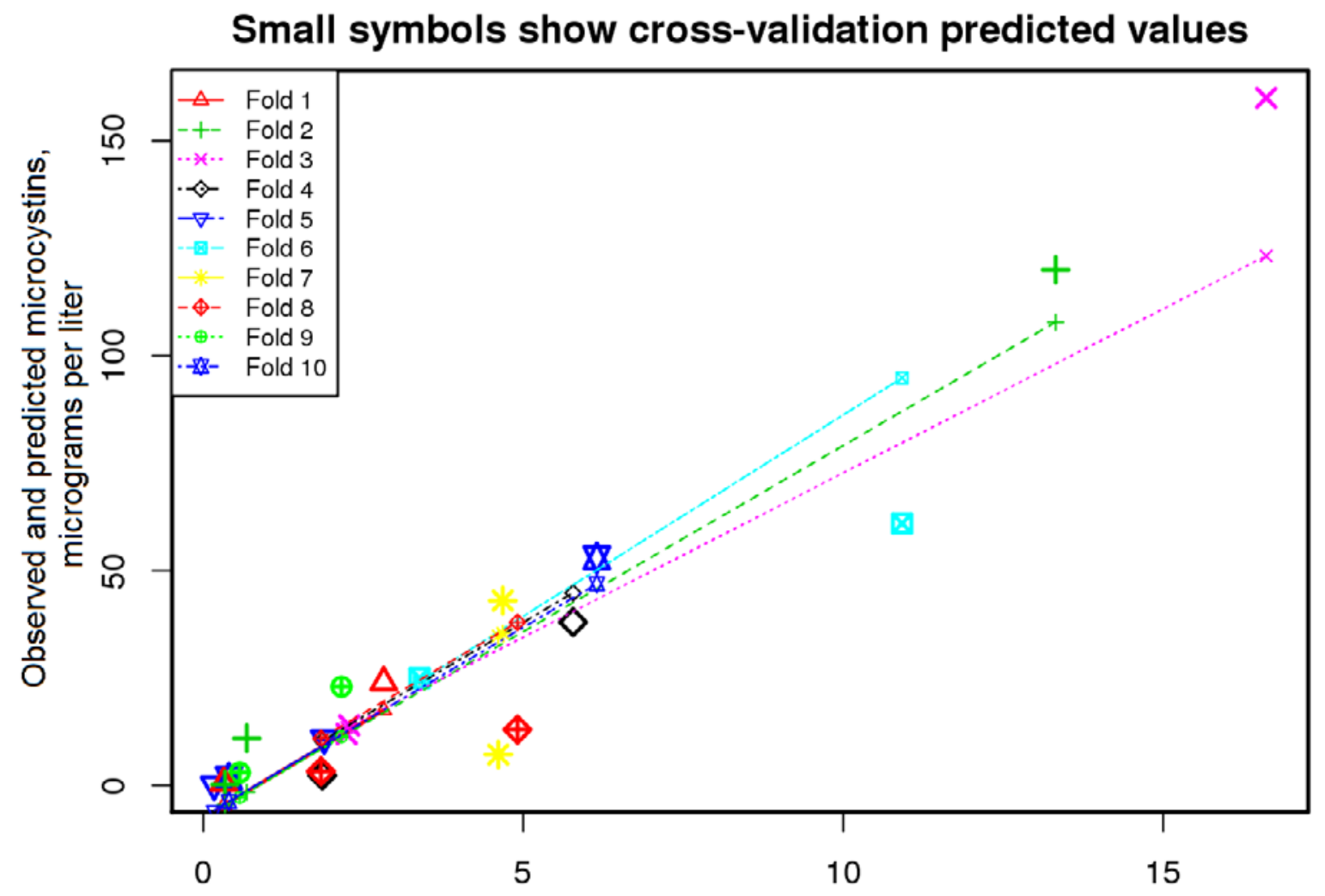

Phycocyanins (cyanobacteria), in situ, relative fluorescence units

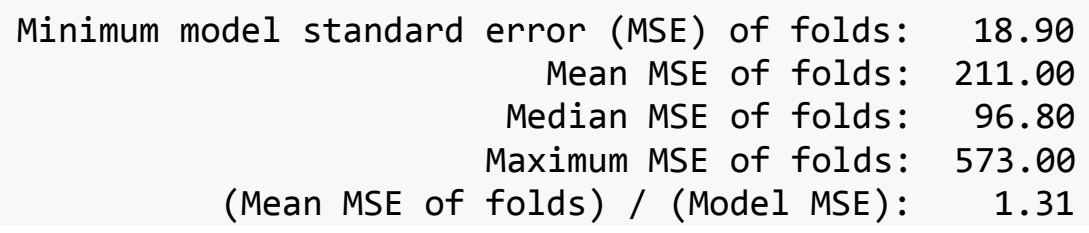




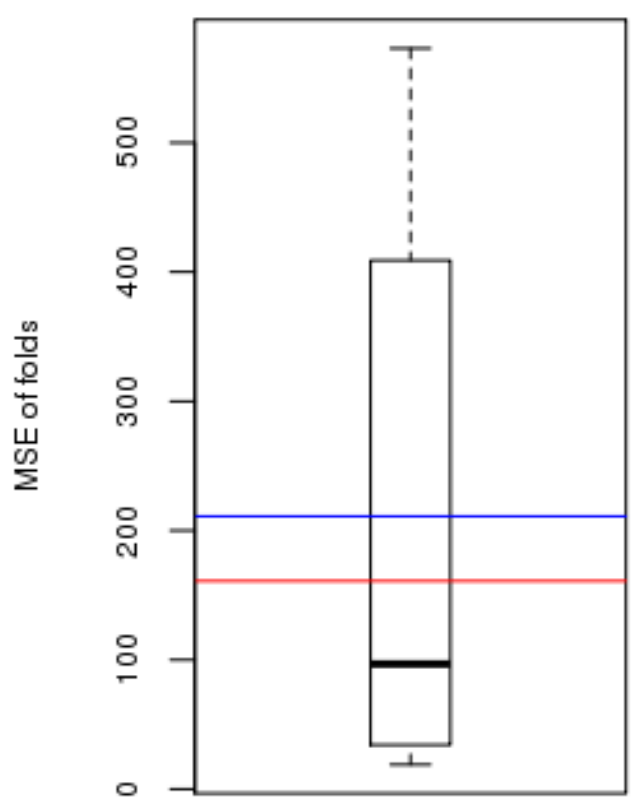

Red line - Model MSE

Blue line - Mean MSE of folds

\section{Model-Calibration Data Set}

\begin{tabular}{|c|c|c|c|c|c|c|c|c|}
\hline 0 & date & time & Lab_MC & Sensor_Pcy & $\begin{array}{r}\text { Computed } \\
\text { Lab_MC }\end{array}$ & Residual & $\begin{array}{r}\text { Normal } \\
\text { Quantiles }\end{array}$ & $\begin{array}{r}\text { Censored } \\
\text { Values }\end{array}$ \\
\hline 1 & $7 / 27 / 2015$ & $8: 30$ & 38 & 5.78 & $4 \overline{4} .1$ & -6.15 & -0.667 & -- \\
\hline 2 & $7 / 27 / 2015$ & $8: 40$ & 7.2 & 4.61 & 33.9 & -26.7 & -1.46 & - \\
\hline 3 & $7 / 27 / 2015$ & $9: 10$ & 160 & 16.6 & 139 & 20.7 & 1.93 & - \\
\hline 4 & $7 / 27 / 2015$ & $9: 40$ & 13 & 4.91 & 36.5 & -23.5 & -1.19 & -- \\
\hline 5 & $7 / 27 / 2015$ & $11: 00$ & 11 & 0.68 & -0.678 & 11.7 & 1.46 & - - \\
\hline 6 & $7 / 27 / 2015$ & $11: 30$ & 12 & 2.24 & 13 & -1.03 & -0.532 & - \\
\hline 7 & $7 / 27 / 2015$ & $11: 50$ & 11 & 1.89 & 9.96 & 1.04 & -0.286 & - - \\
\hline 8 & $7 / 27 / 2015$ & $12: 50$ & 2.3 & 1.86 & 9.69 & -7.39 & -0.986 & - - \\
\hline 9 & $7 / 27 / 2015$ & $13: 20$ & 3.3 & 1.84 & 9.52 & -6.22 & -0.816 & - - \\
\hline 10 & $7 / 27 / 2015$ & $14: 30$ & 0.21 & 0.17 & -5.16 & 5.37 & 0.406 & - - \\
\hline 11 & $7 / 27 / 2015$ & $15: 40$ & 14 & 2.28 & 13.4 & 0.615 & -0.406 & - \\
\hline 12 & $8 / 31 / 2015$ & $9: 10$ & 61 & 10.9 & 89.3 & -28.3 & -1.93 & -- \\
\hline 13 & $8 / 31 / 2015$ & $9: 20$ & 25 & 3.38 & 23.1 & 1.95 & -0.17 & -- \\
\hline
\end{tabular}




\begin{tabular}{|c|c|c|c|c|c|c|c|}
\hline 14 & $8 / 31 / 2015 \quad 9: 40$ & 120 & 13.3 & 110 & 9.58 & 0.986 & -- \\
\hline 15 & $8 / 31 / 2015 \quad 10: 00$ & 43 & 4.68 & 34.5 & 8.52 & 0.816 & -- \\
\hline 16 & $8 / 31 / 2015 \quad 10: 50$ & 53 & 6.15 & 47.4 & 5.6 & 0.532 & -- \\
\hline 17 & $8 / 31 / 201511: 30$ & 24 & 2.82 & 18.1 & 5.87 & 0.667 & -- \\
\hline 18 & $8 / 31 / 2015 \quad 12: 10$ & 23 & 2.16 & 12.3 & 10.7 & 1.19 & -- \\
\hline 19 & $8 / 31 / 2015 \quad 13: 10$ & 1.7 & 0.4 & -3.14 & 4.84 & 0.286 & -- \\
\hline 20 & $8 / 31 / 201514: 00$ & 3 & 0.57 & -1.65 & 4.65 & 0.17 & - \\
\hline 21 & $8 / 31 / 201515: 10$ & 0.54 & 0.32 & -3.84 & 4.38 & 0.0565 & - \\
\hline 22 & $8 / 31 / 2015 \quad 15: 30$ & 0.21 & 0.34 & -3.67 & 3.88 & -0.0565 & -- \\
\hline
\end{tabular}

Definitions

Cook's D: Cook's distance (Helsel and Hirsch, 2002).

DFFITS: Difference in fits statistic (Helsel and Hirsch, 2002).

Leverage: An outlier's measure in the $x$ direction (Helsel and Hirsch, 2002). Lab_MC: Total microcystins plus nodularins, unfiltered water, freeze/thaw extraction, ADDA specific enzyme-linked immunosorbent assay, recoverable, micrograms per liter (89011).

LOWESS: Locally weighted scatterplot smoothing (Cleveland, 1979; Helsel and Hirsch, 2002).

MSE: Model standard error (Helsel and Hirsch, 2002).

MSPE: Model standard percentage error (Helsel and Hirsch, 2002).

Probability $(>|t|)$ : The probability that the independent variable has no effect on the dependent variable (Helsel and Hirsch, 2002).

RMSE: Root mean square error (Helsel and Hirsch, 2002).

Sensor_Pcy: in Phycocyanins (cyanobacteria), water, in situ, fluorometric method, excitation at $590+-15 \mathrm{~nm}$, emission at $685+-20 \mathrm{~nm}$, relative fluorescence units (RFU) (32 321).

t value: Student's t value; the coefficient divided by its associated standard error (Helsel and Hirsch, 2002).

\section{References Cited}

Cleveland, W.S., 1979, Robust Locally Weighted Regression and Smoothing Scatterplots: J. Am.

Stat. Assoc. 74, 829-836.

Helsel, D.R., and Hirsch, R.M., 2002, Statistical methods in water resources-Hydrologic analysis and interpretation: U.S. Geological Survey Techniques of Water-Resources Investigations, book 4, chap. A3, 510 p.

U.S. Geological Survey, variously dated, National field manual for the collection of water-quality data: U.S.

Geological Survey Techniques of Water-Resources Investigations, book 9, chaps. A1-A9. 
For more information about this publication, contact: Director, USGS Kansas Water Science Center 4821 Quail Crest Place

Lawrence, KS 66049

(785) 842-9909

Or visit the Kansas Water Science Center Web site: https://ks.water.usgs.gov 


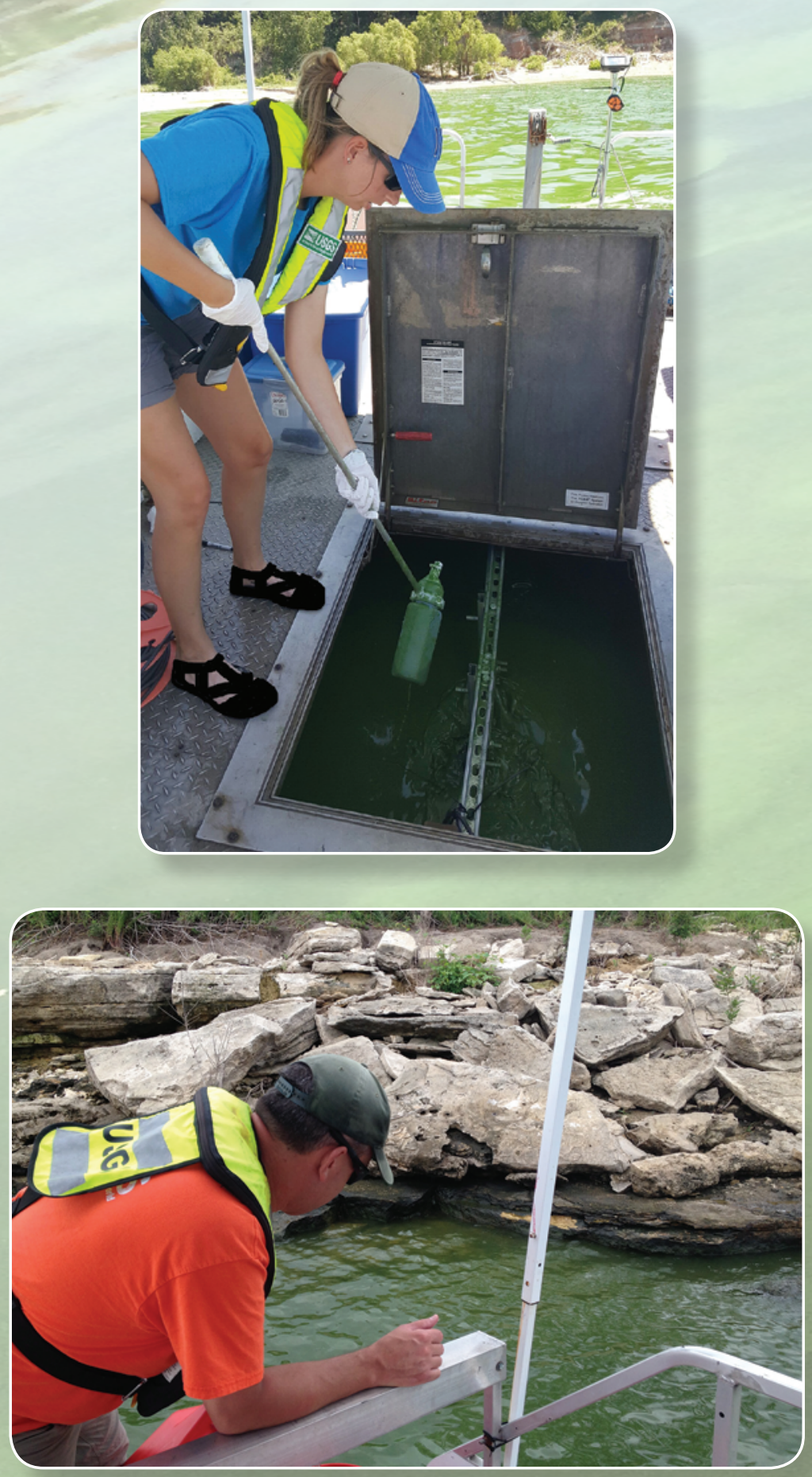